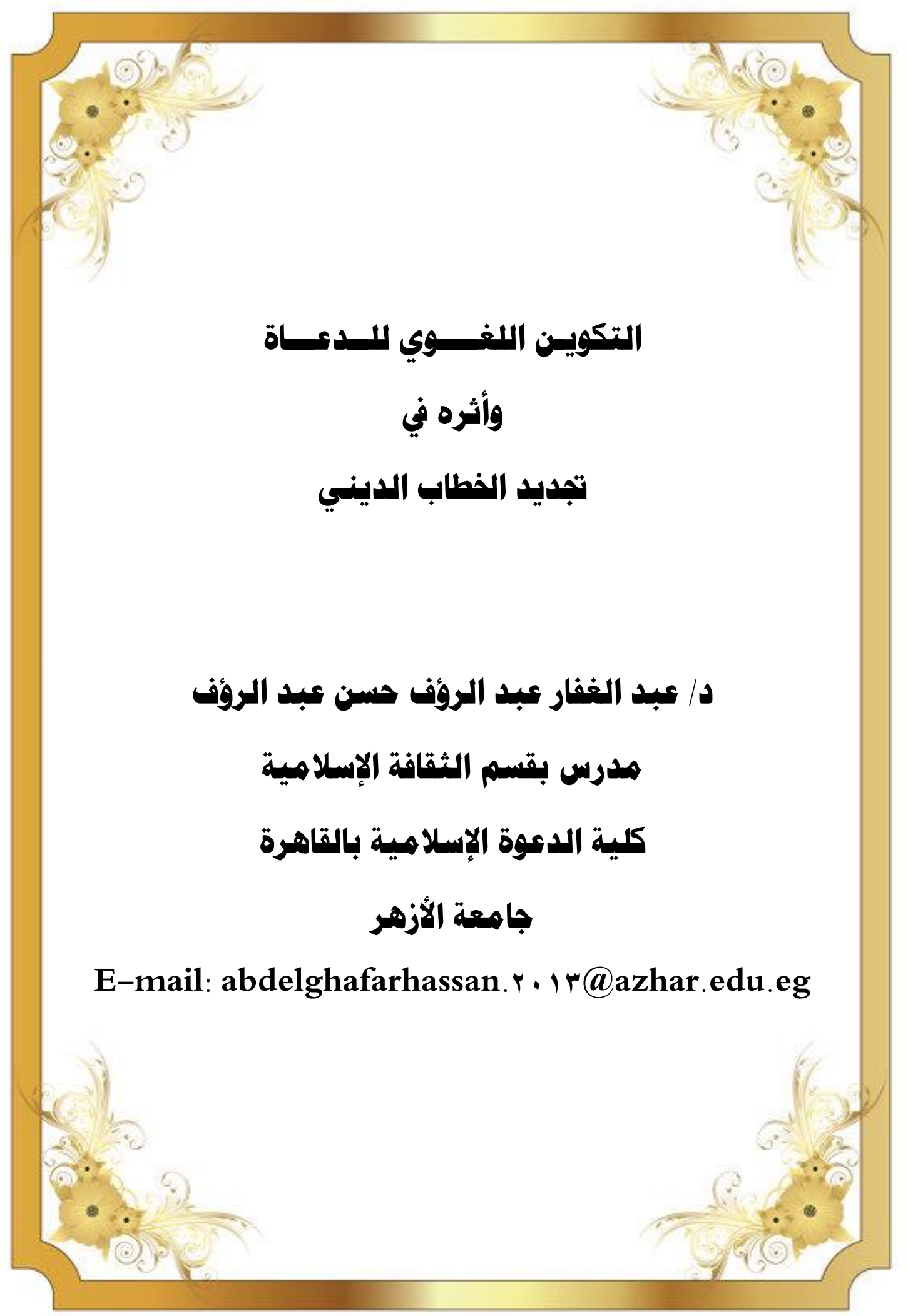


كer التكوين اللغوي للدعاة وأثره في تجديد الحطاب الديني

\section{التكوين اللغوي للدعاة وأثره في تبديد الغطاب الديني}

$$
\text { د. عبد الغفار عبد الرؤف حسن عبد الرؤف }
$$

مدرس بقسم الثقافة الإسلامية - كلية الدعوة الإسلامية بالقاهوة

$$
\text { جامعة الأزهر }
$$

البريد الإلكترولي: abdelghafarhassan.r.1\%@azhar.edu.eg

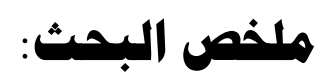

يعالج البحث بعض الإثكالات الدعوية، بتوجيهِ النظرِ إلى وجهٍ من وجوه الإعداد الثقافي الإِي

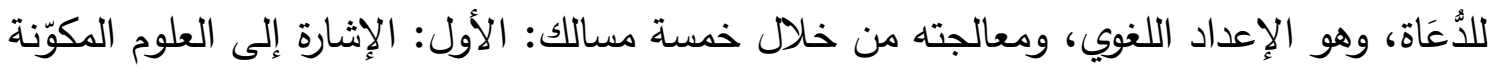
للعقلية الدعوية مع تِبْيَان العلوم اللغوية الاثني عشر وعلاقتها بالهُوية الإسلامية. الثاني: استقراء

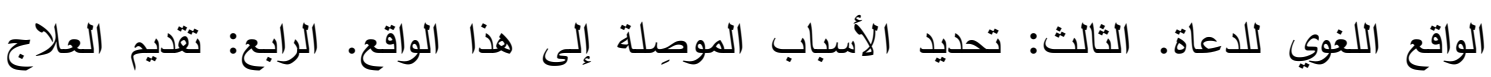
لمناهضة هذا الواقع المؤلم. الخامس: بيان أثر اللغة في تجديد الخطاب الديني. وتوصَّل البحث إلى أنَّ ضعْفَ بعضُ الدعاةِ في العلوم العربية يرجع إلى عدة أسباب،

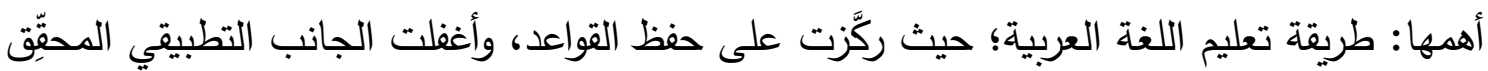

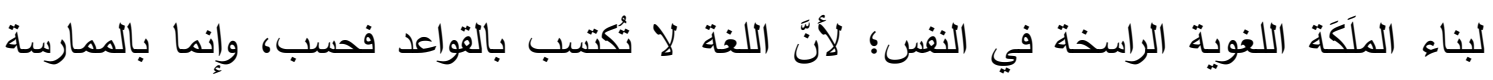
والتَّكْرار

وظهر أنَّ الجهل باللسان العربي يُوقِع الدعاة في استنطاق نصوص الوحي ما لا تحتمله

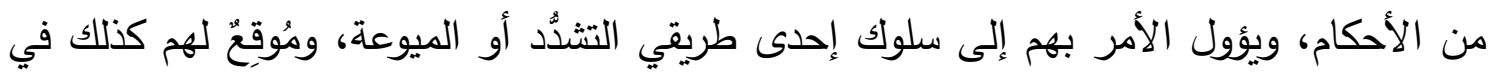

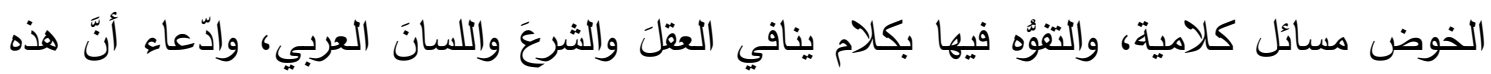
التناقضات مراد الثارع الحنيف. الكلمات المفتاحية: التكوين اللغوي - الدعاة - العلوم العربية - تجديد الخطاب الديني. 
كبع التكوين اللغوي للدعاة وأثره في تجديد الحطاب الديني

The linguistic Composition of the Preachers and Its Effect on the

\title{
Renewal of Religious Discourse
}

\author{
Dr. Abdel Ghaffar Abdel Raouf Hassan Abdel Raouf
}

Lecturer, Department of Islamic Culture, Faculty of Islamic Dawah in Cairo,

\section{Al-Azhar University}

\section{Search Summary:}

The research addresses some of the issues of propaganda, by drawing attention to one of the facets of the cultural numbers of the da'is, which is the language numbers, and addressing it through five questions: First, referring to the constituent sciences of the da'i mentality with the manifesto of the twelve linguistic sciences and their relation to Islamic identity. Second: To extrapolate the linguistic reality of the preachers. Third: Identifying the reasons for this reality. Fourth: To provide treatment against this painful reality. Fifth: Statement of the effect of language on the renewal of religious

discourse.

The research found that the weakness of some of the preachers in the Arab sciences is due to several reasons, the most important of which is the way the Arabic language is taught; It focused on maintaining the rules and overlooked the verified practical aspect of building a strong linguistic queen;

Language is acquired not only by norms, but by practice and repetition.

It appeared that ignorance of the Arabic tongue led the preachers to spread the texts of the revelation in the unthinkable judgments, and it led them to take one of the hard or coarse ways, and put them in speaking matters, and to speak in them in words that are contrary to the mind, the Sharia, and the Arab tongue, and claim that these contradictions are synonymous with the true street.

Key words: linguistic composition - preachers - Arab sciences renewal of religious discourse. 


\section{همقدهة}

لك الحمد يا مَن تقدَّست عن التشبيه والتمثيل، ويسَّرت لنا الوصول إلى حقيقة المعاني بأوضح مجاز وسبيل، والصلاة والسلام على نبيك المرسَل إلى الخلق بالهداية، سيدنا محمد الذي لئي

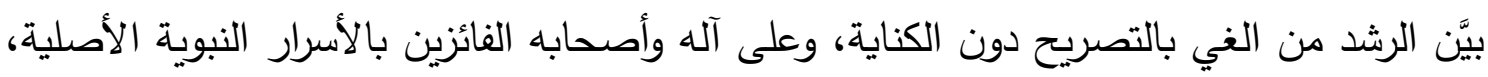

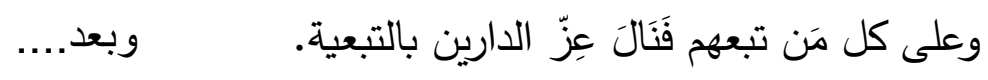

فإنَّ الدعوة الإسلامية تتعرَّض في هذه الآونة لسيل جارف من الثُّبَه والثَكوك المثارة حول

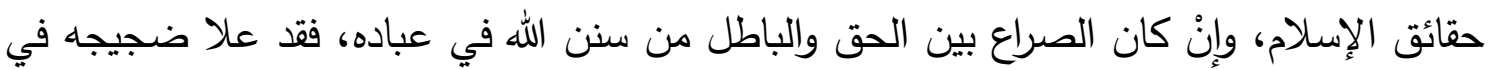
هذا الزمان، واشتدّ صخبه، وتلاطمت أمواجه، واختلطت مسالكه، فوقع العامَّة في حَيْرة وقلق،

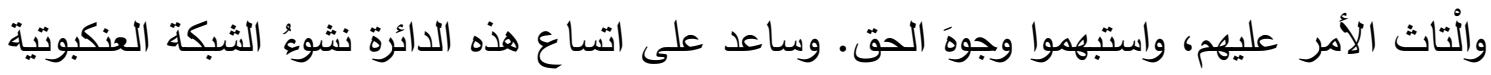

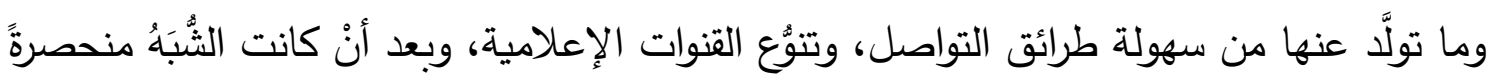
في دوائر بحثية غدت في كل بيت، بل في كل حجرة سوله

ومن الهموم الدعوية أنْ يكون تعائلَ الدعاة إزاء هذه السهام إما بالمجابهة اللسانية المجرَّدة

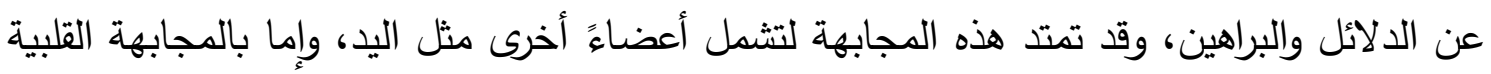

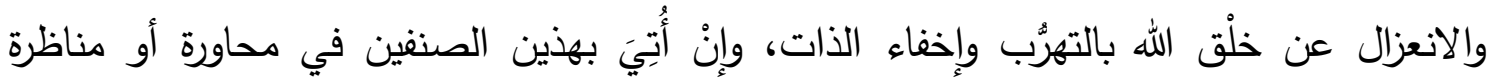

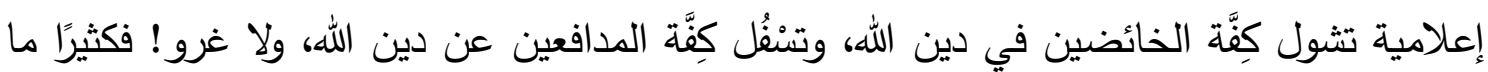
تسقط الحقوق لعجز أصحابها عن العَرْض والإثبات.

وإسقاط هذه الثُشَبه، وإزالة تلك الثكوك التي يتعرَّض لها الجهال أو المغرضون لا يقتصر

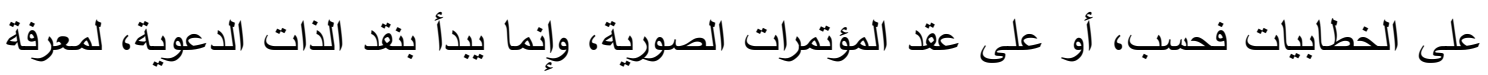

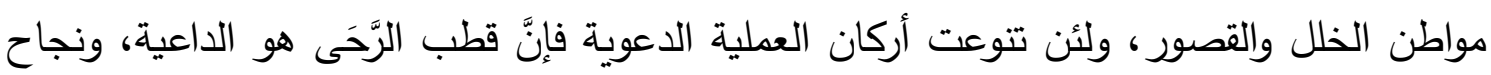
دعوته منوطُ بإعداده وتهيئته.

وهذا البحث يُعنى بوجهٍ من وجوه الإعداد الثقافي للداعية، وهو الإعداد اللغوي، وتظهر

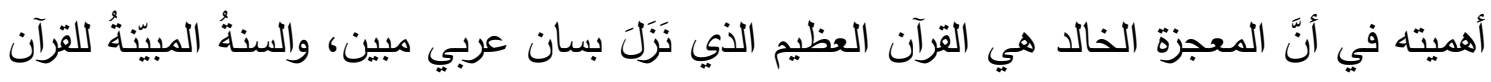
بلسان عربي كذلك، والقرآن والسنة مصدران من مصادر التشريع الإسلامي، فاستنباطُ الأحكامٍ الثرعية يتوقف على فهُم هذا اللسان العربي، ومعرفةِ معهود العرب الذين نزل علئه اليهم القرآن،

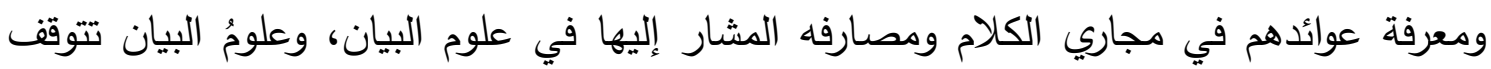

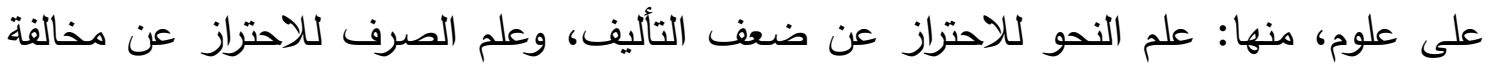

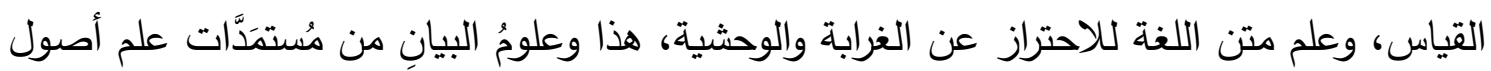




\section{حولية كلية الدعوة الإسلاهية بالقاهرة}

\section{كعبالتكوين اللغوي للدعاة وأثره في تجديد الحطاب الديني}

الفقه الذي يُعنى باعتصار الأحكام الشرعية من نصوص الوحي الشريف، ولك تلاحظ أنَّ علم أصول الفقه لغةٌ وزيادة، وأنَّ استخراج الأحكام الشرعية يخضع لمعياريَّة دقيقة تشتمل على جملة من العلوم مترابطة ومتكاملة، وأنَّ الفوضى الحاصلة الآن في إطلاق لسان بعض الدعاة لأحكام جزافية إنما ينتج عن الابتعاد عن تلك العلوم، والانصياع للأهواء والرغائب.

\section{أسباب الاختيار:}

( ) ) ضعْف المستوى اللغوي لبعض الاعاة.

r ) تصوُر بعض الاعاة أنَّ تحصيل اللغة العربية ينحصر في إقامة أواخر العَلم بالإعراب والبناء.

r) تأثير اللغة العربية في ضبط العقلية الاعوية في مجالَيْ الثرعيات والعقليات.

\section{أهداف البحث:}

1) تبيين العلوم المكوّنة للعقلية الدعوية على وجه العموم، والعلوم العربية المكوّنة لها على وجه الخصوص.

r) استقراء العوامل الصانِعة للضعف اللغوي عند الدعاة، والكشف عن العوامل المحقّة لارتقائهم اللغوي.

r) إظهار بعض ملامح التكامل المعرفي بين العلوم العربية والعلوم الثرعية والعقلية. ع) التليل على أثر العلوم العربية في استخراج الأحكام الثرعية من أدلتها التفصيلية.

\section{الدراسات السابقة:}

توجد دراسات تتعلق بشيء من جزئات هذا البحث، نحو: أثر الارس اللغوي في فهم النص الثرعي: أ.د// محمد المختار محمد المهدي، حولية كلية الدراسات الإسلامية والعربية بالقاهرة، العدد السابع عشر، 19 19 اهـ - 999 (ام، وهي تُعنى ببيان الأثر المعنوي لمعرفة كل من المعنى اللغوي، والمعني الصيغي، والموقع الإعرابي، والسياق.

\section{هنهمج البمث:}

\section{يقوم بينان البحث على منهجين:}

الأول: المنهج الاستقرائي: ويقوم على تصفُّح الجزئيات والوصول منها إلى حكم كلي. الثاني: المنهج التحليلي: ويقوم على تحليل عدد من الأمور تحليلً علميًا لاستخراج النتائج من 


\section{حولية كلية الدعهوة الإسلامية بالقاهرة}

كعالتكوين اللغوي للدعاة وأثره في تجديد الحطاب الديني

هطة البمث:

يَنْتَظٌُُ الكلام في تمهيد، وخمسة مباحث على النحو الآتي:

المبحث الأول: العلوم العربية وعلاقتها بالهوية الإسلامية.

المبحث الثاني: الواقع اللغوي للدعاة.

المبحث الثالث: مقوضات الازدهار اللغوي للدعاة.

المبحث الرابع: عوامل تنمية الملكة اللغوية للاعاة.

المبحث الخامس: آثار التمكُّن من العربية في تجديد الخطاب الديني. 


\section{تصرير هدلول بعض همطاحمات عنهان البحث}

تستتير في هذا التمهيد غوامض بعض المصطلحات الواردة في عنوان البحث؛ حيث يتضح مفهوم اللغة، ويتحرَّر محل النزاع في تعيين واضعها، ويظهر مدلول مصطلح (تجديد الخطاب الديني)، والقرق بينه وبين التغيير، وأخيرًا الإثشارة إلى علامات وات الخعات الخطاب الديني الرشيد.

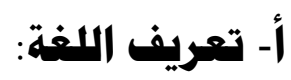

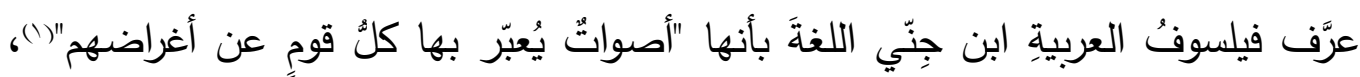

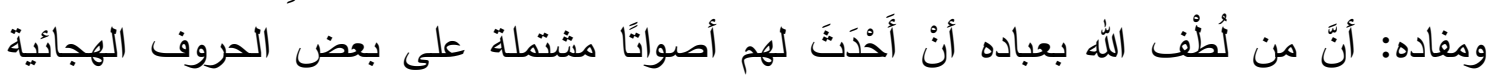

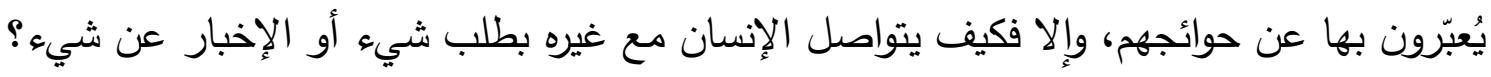
ولولا ذلك لكان الإنسان كالجماد بيد أنه يتحرَّك.

وتعريف ابن جني السابق من أفضل التعاريف؛ لاشتماله على عِدَّة لطائف، منها:

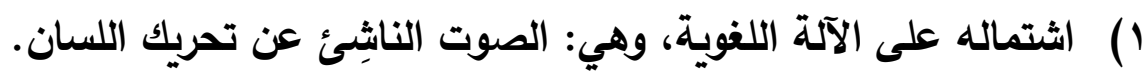

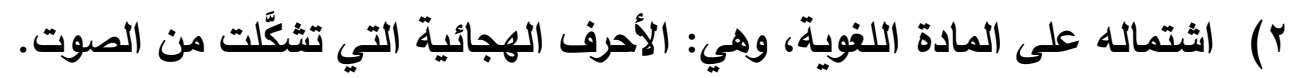

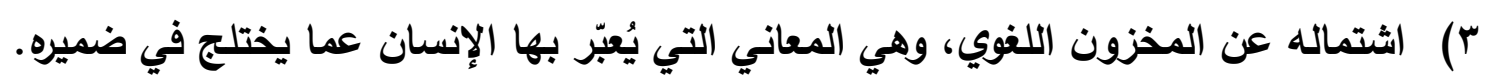
\&) اشتماله على الغائية اللغوية، وهي: التعبير عن الأغراض والحوائج. ب- واضع اللغة:

اختُلفَ في وضْع اللغة: أهو أمر توقيفي، أي: وضعه الله تعالى، أم أمر اصطلاحي، أي:

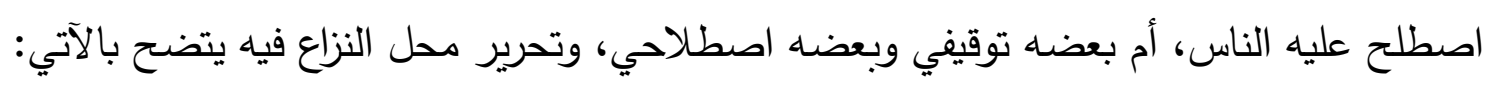
ا ـ أسماء الله والملائكة، واضعها الله اتفاقًا.

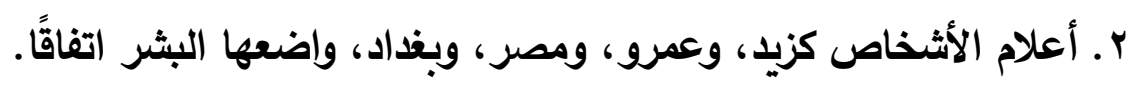

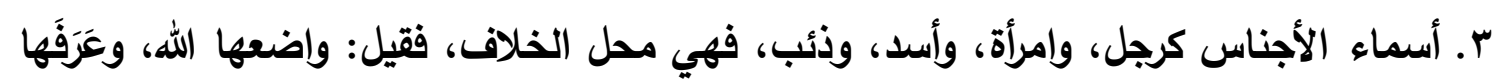

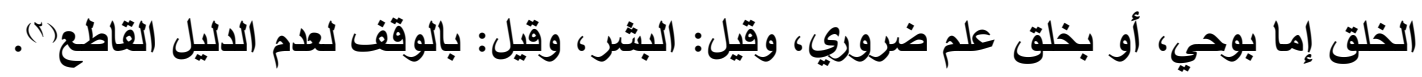

') الخصائص لابن جني، تحقيق: الأستاذ/ محد علي النجار، الككتبة العلمية عن طبعة دار الكتب الدصرية,

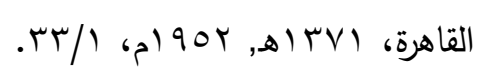

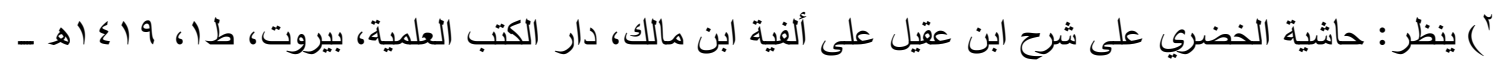

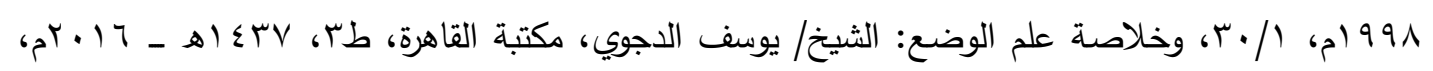




\section{جـ - هفهوم تجديد الغطاب الديني:}

يراد به كمركب لقبي: "إحياء ما اندرس من تعاليم الإسلام، واستثمار الآليات الحديثة في

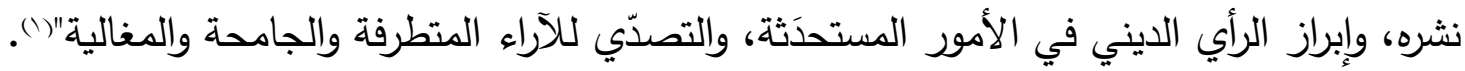

$$
\text { يفيد التعريف أنَّ محورية التجديد تتمثل في أمرين: }
$$

أولهما: المحافظة على أصول الدين بإحياء ما انطمس منها، وتخليصها مما زَاحَمَهَا من

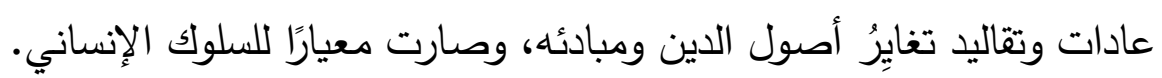

ثانيهما: تنويع طرق عَرْض الدين بحيث تناسب التطوُر الزماني، والتقدُّم التّقني، فيراعي

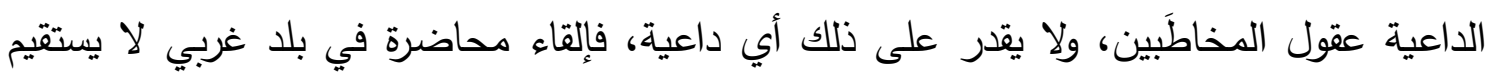

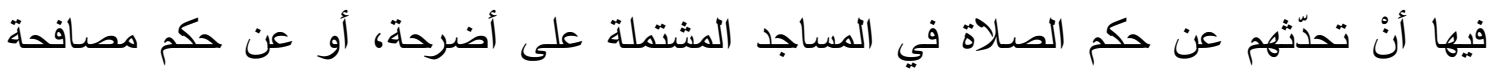

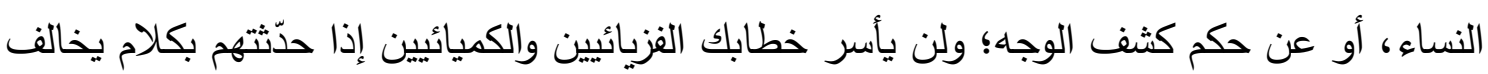

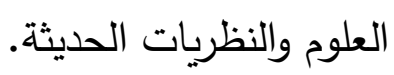

إن قوة الداعية ليس بمجرد حفظ خطب رنانة، أو التكلم بسجع بارد، أو التثدُّق بمله الفم

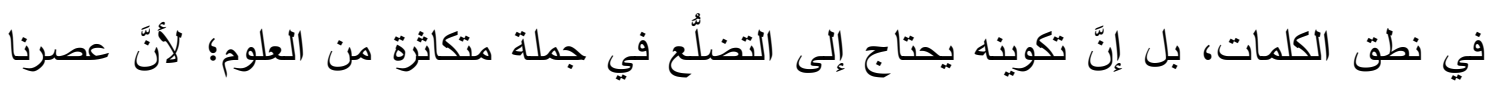

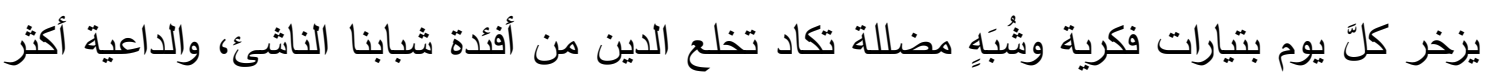
المعنيين بالشرع مخالَطةً للناس عامّهم وخاصّهم.

\section{د - الفرق بين التجديد والتغيير:}

يتلخص الفرق بينهما بأنَّ التجديدَ إحياءٌ للأصول، والتغيير مسخٌ للأصول وتشويهُ لها،

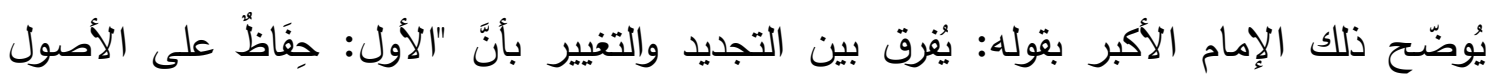

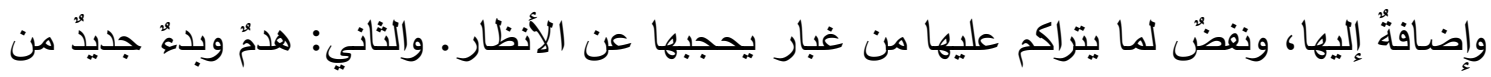

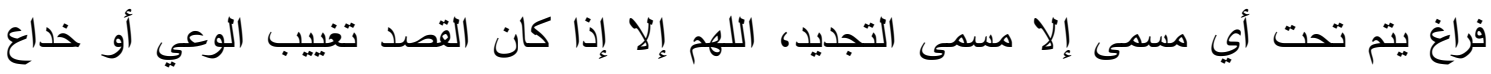

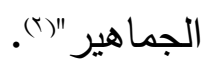

') من جهود الأزهر في التجديد: تقديم: أ.د/ عباس شومان، هدية مجلة الأزهر، عدد: رجب (اء؟ (هـ - مارس r.

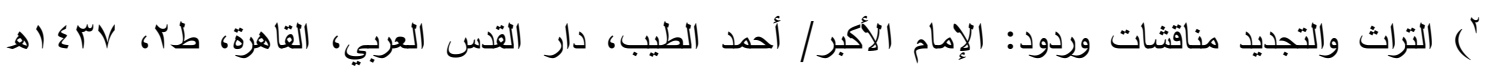
(1) 


\section{هـ - شروط التجديد الحقيقي:}

( ) أن ينشأ التجديد من داخل الثقافة المتكاملة المتماسكة الحيّة في أنفس أهلها، أي: الذاتية

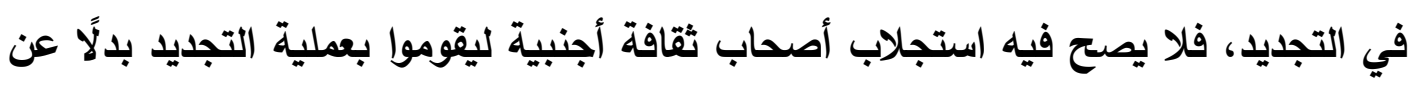
أصحاب الثقافة.

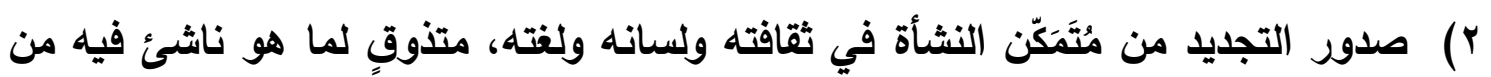

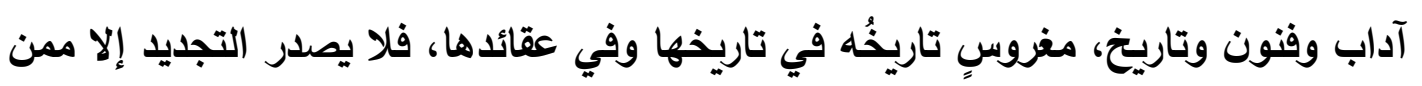

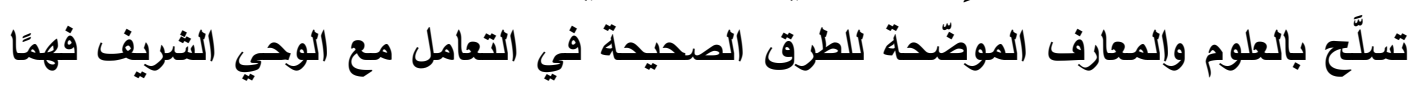
واستنباطًا وتوظيفًا.

r) الحوار الذكي بين التفاصيل الكثيرة المتثابكة المعقدة التي تنطوي عليها هذه الثقافة وبين

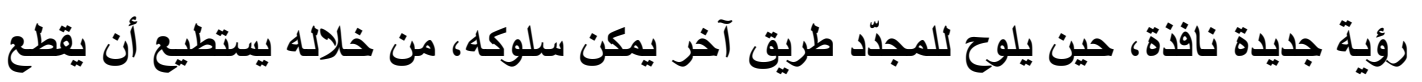

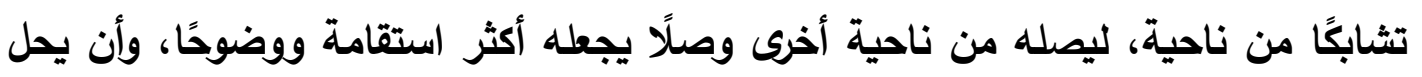

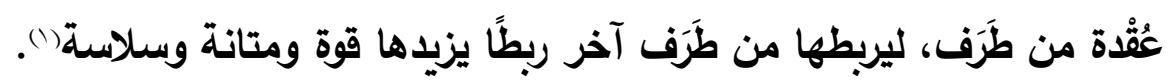

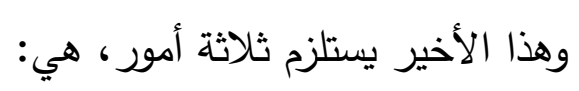

1) الثعور بالمسؤولية إزاء الحفاظ على الأوطان، والرغبة الحقيقية في إعلاء شأنها، التهاء والتصدّي لمحاولات هدمها أو زعزعتها.

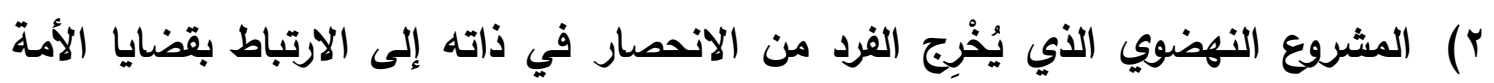
الإسلامية وهمومها.. r) رصد التعديات الاجتماعية السائد التي تواجه الأمة، وتحليلها، وتقديم العلاج الناجع لها على المستوى الفردي والجماعي). ويقابلُ التجديدَ الحقيقيَّ التجديدُ المزيفُ، ومن علائمه:

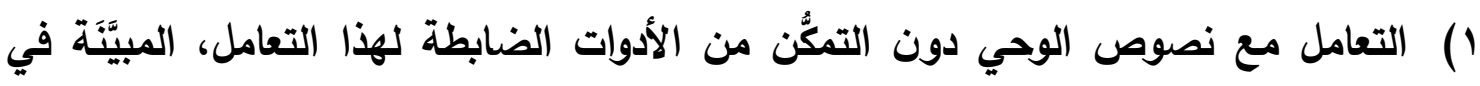

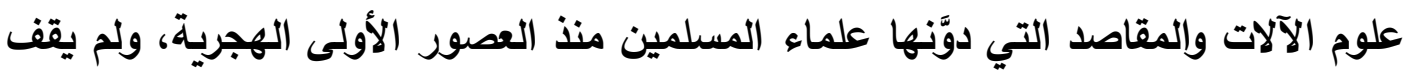

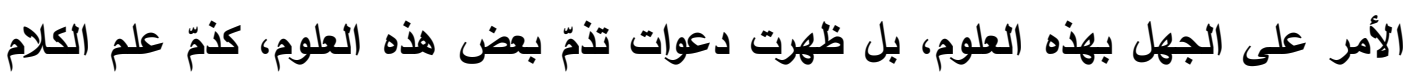

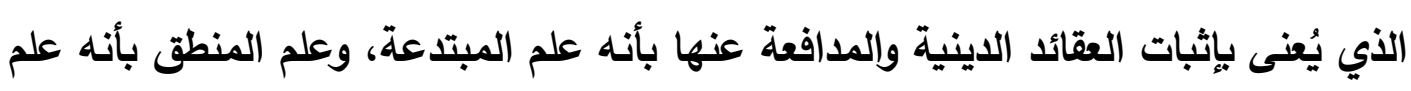
') أصل الشروط الثلاثة من كتاب: رسالة في الطريق إلى ثقافتتا: الأستاذ/ محمود محمد شاكر ، مكتبة الخانجي

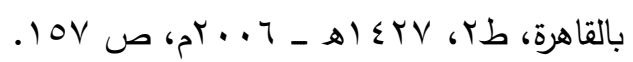

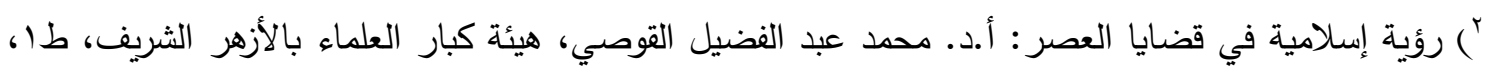

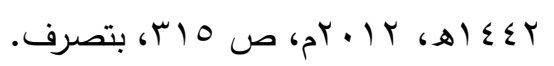




\section{حولية كلية الدعهوة الإسلاهية بالقاهرة}

كعبالتكوين اللغوي للدعاة وأثره في تجديد الخطاب الديني

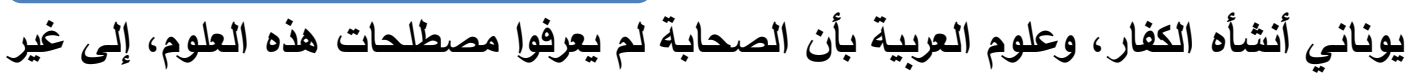
ذلك من هذه الأباطيل التي أشاعها الجهال، ومكَّنهم من إثاعتها أصحاب الأغراض والمصالح)' (1) (1) (1)

r) القطيعة مع الدولة، والأحادية في الحوار الإنساني، والعدائية والتصادمية لكل مَن يخالِف الرأي والفكر .

r) الاستعلاء، "فهو خطاب ينظر لغيره على أنهم أقزام، وهو وحده من بين الفرقاء العملاق الأوحد الأي ينفرد بمعرفة مراد الله تعالى ورسوله يَّلّ من نصوص الوحي... ومن شر ما ابتلي أصحاب الخطاب به: الانتفاخ العلمي الأجوف؛ إذ يتطاولون على المؤسسات العلمية ذات الأصالة والعراقة التي عاش الفكر ولا يزال يعيش في أحضانها"((). ء) الانعزال عن واقع المسلمين ومشكلاتهم، واصطناع مشكلات وهمية، نحو: إغضاء الطرف عن كل المشكلات الدعوية في مصرنا الحبيبة، والداعوة مثلًا إلى تحذير العوام من مخاطر الثيعة في مصر ! نعم إنها مضحكات مبكيات.

ولإعانة الدعاة على تجديد الخطاب الديني الذي يتفاعل مع الواقع كان هذا البحث المبيّن لجانب من جوانب الإعداد الثقافي ضمن منظومة المعارِف المشكّلة للعقلية الدعوية، إذ وهن الدعاة في هذه العلوم المكوّنة لهم يؤدّي إلى إرباك في المشهد الدعوي، وكلُّ دعوةٍ إلى التجديد وما يُضارِعه من مصطلحات إنْ لم تتطلق من البناء العلمي للدعاة أو العمل على ترميمه وتتميته،

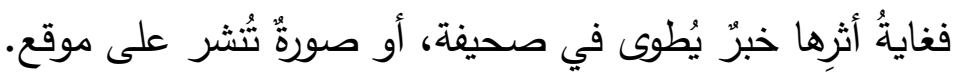

') ينظر : خلاصة القواعد المنطقية: د/ عبد الغفار عبد الرؤوف حسن، تقديم: أ.د/ صابر أحمد طه، أ.د/ محمد

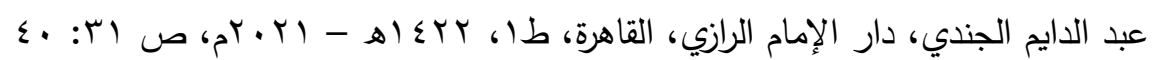

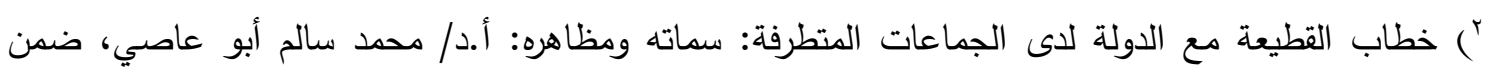

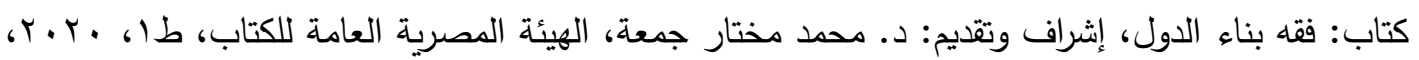




\section{المبحث الأول}

\section{العلوم العربية وعلاقتها بالهوية الإسلاهيية}

الكلام هنا عن أنواع المعارف في المنظومة المعرفية الأزهرية وموقع العربية منها، والعلاقة

الترابطية بين اللغة والهوية الإسلامية من خلال هذين المطلبين:

\section{المالب الأول}

\section{أنواع المعارف في المنظوهة المعرفية الأزهرية}

إنَّ المؤسسة المعنيّة بتخريج الدعاة الحاملين للرسالة الإسلامية والمدافعين عنها هي مؤسسة الأزهر العظيم، والعقلية العلمية فيها تتكون من أربعة أنواع من العلوم المتكاملة، هي: أولًا: العلوم النقلية، أي العلوم التي نشأت حول القرآن الكريم والسنة المطهرة من التفسير، وعلوم القرآن، والحديث، وعلومه، والفقه، وأصوله، وعلوم السيرة، وكليات العقيدة ومسائلها، وكل علم يكون النص فيه هو الموضوع الذي تدور عليه مسائل هذا العلم، ويستقل الدليل النقلي فيه بإثباتها والاحتجاج عليها.

ثانيًا: العلوم العقلية، ويقصد بها العلوم التي يكون مأخذ البرهنة فيها من بدهيات العقل أو نظرياته، وذلك مثل علم أصول الدين، وهو الذي يسمى بعلم الكلام أو علم التوحيد أو الفقه الأكبر، ومثل الفلسفة الإسلامية، ومثل المنطق اليوناني بعد أن طوره المسلمون وأضافوا إليه كثيرًا مما كان ينقصه في بيئته الإغريقية.

ثالثًا: العلوم الأوقية، والمقصود بها التصوف الإسلامي لكل مشاربه الذوقية، وتجاربها الروحية، وقد ذَكَرَ هذه الثلاثة الإمام الأكبر (1)، وأرى أنَّ هناك نوعًا رابعًا من مكوّنات العقلية الأزهرية، فتصير الأنواع أربعة:

لابعًا: العلوم التجريبية، وهي العلوم التي قوامها الملاحظة والتجربة، كالفيزياء والكمياء، "والعلم التجريبي يعرف الطبيعة التفاعلية والتحليلية للعناصر، ولا يعرف طبيعتها الميتافيزيقية التي هي العلة في الطبيعة التفاعلية والتحليلية"(؟)، أي: وظيفته التحليل والتفسير، لا التعليل والتسبيب، ') دليل معلمة المناهج الأزهرية (قائمة بالكتب المعتمدة في الأزهر الشريف)، تقديم: الإمام الأكبر/ أحمد الطيب،

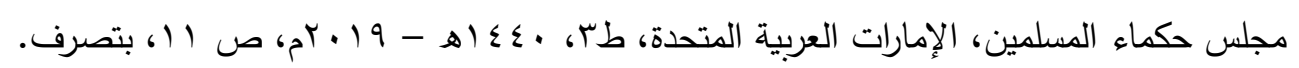

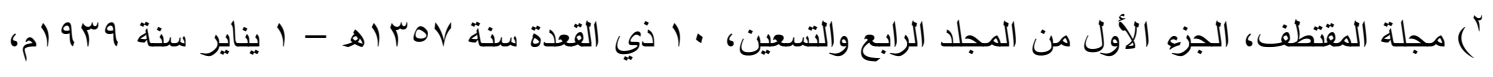

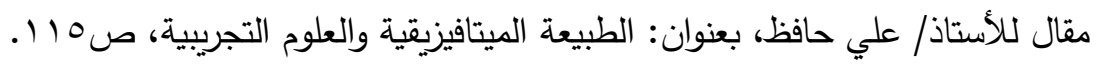




\section{حولية كلية الدعهوة الإسلاهية بالقاهرة}

كeي التكوين اللغوي للدعاة وأثره في تجديد الحطاب الديني

ولا غنى للعقلية الأزهرية عن الوقوف على مبادئ هذه العلوم التجريبية.

\section{هوقع العربية هن المنظوهة المعرفية الأزهرية:}

علم العربية - ويُسمَّى بعلم الأدب - من العلوم النقلية، وهو علمّ يُحترز به عن الخلل في

كلام العرب لفظًا وخطًا، أي: كتابة، وعدد علومه اثنا عشر علمًا (1)، وقد نُظِمَت في قول بعضهم:

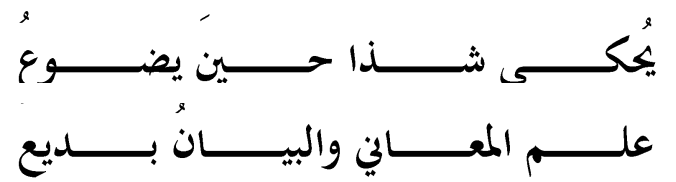

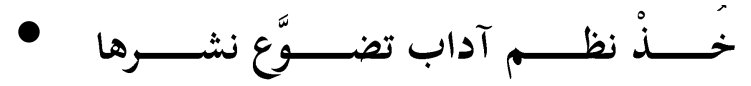

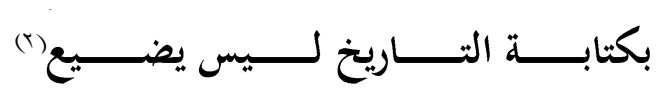

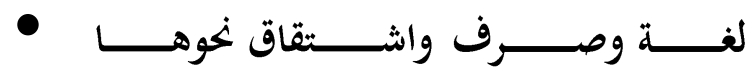

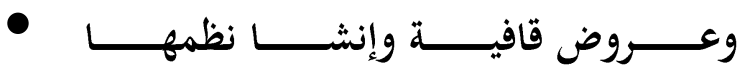

إلا أنَّ العطَّر نَظَمَهَا وجَعَلَ علم البديع تابعًا لعلمَي المعاني والبديع، ووضـع مكانه علم

قرض الشعر، قال: وقد يطلق علم العربية على مجموع اثني عشر، جمعتها في قولي:

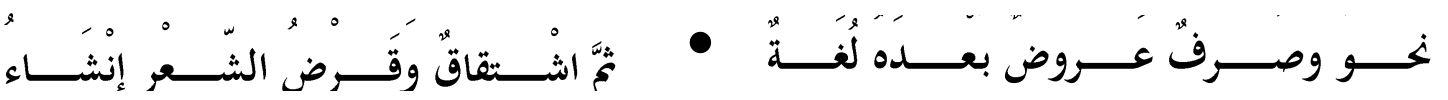

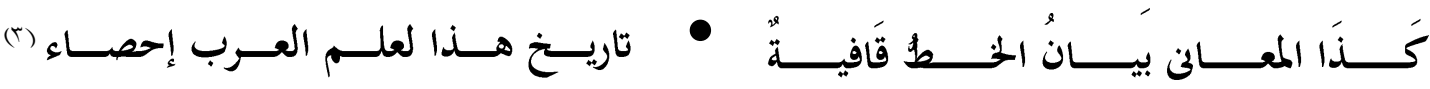

وعلى منوال العطار نسج السُّجاعي إلا أنه استبدل علم التاريخ بعلم المحاضرات، يقول:

(والعربية منسوبة للعرب، وهي علم يحترز به عن الخلل في كلام العرب، وهو بهذا المعنى يشمل اثني عشر علمًا، جمعها بعض أصحابنا في قوله:

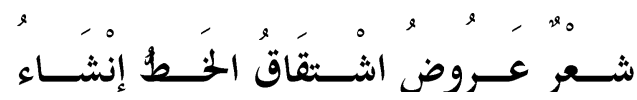

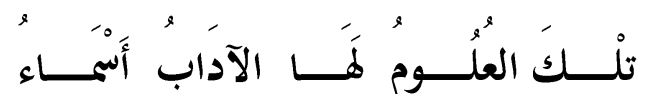

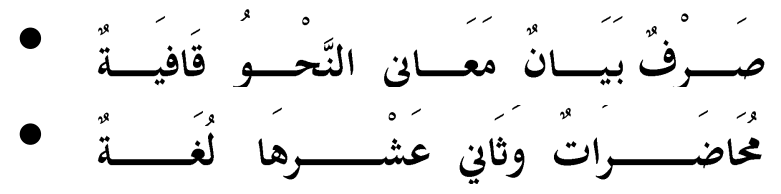

ثم صار ـ أي: علم العربية ــ علمًا بالغلبة على علم النحو)(ع).

وجه تقعيم هذه العلوم:

') ينظر : المواهب الفتحية في علوم اللغة العربية: الثيخ/ حمزة فتح الله، المطبعة الأميرية بمصر، طا، ب آساه، (اله $.11 / 1$

r) الوسيلة الأدبية إلى العلوم العربية: حسين المرصفي، تحقيق: د/ عبد العزيز الدسوقي، الهيئة الدصرية العامة

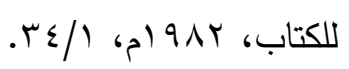

r

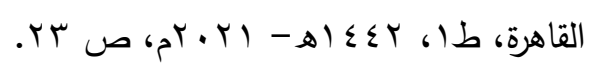

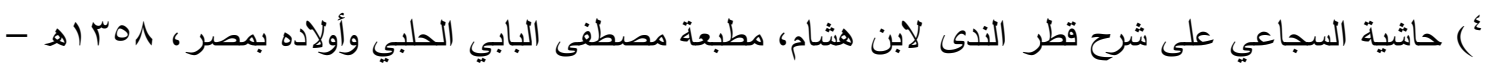
. $\vee$ ص م (9) 
كع التكوين اللغوي للدعاة وأثره في تجديد الخطاب الديني

نقل الشيخ محمد أبو عليان الثافعي عن السيرامي الوجه في تقسيم هذه العلوم بقوله: "الباحث عن حال جوهر اللفظ ومادته اللغة، وعن أصله وفرعه الاشتقاق، وعن هيئته التصريف، وعن حال آخره إعربًا وبناءً النحو، وعن حال مطابقته الحال المعاني، وعن اختلافه في التعبير به عن المعنى الواحد وضوحًا وخفاءً البيان، وعن محاسنه البديع، وعن وزنه العروض، وعن آخره الموزون

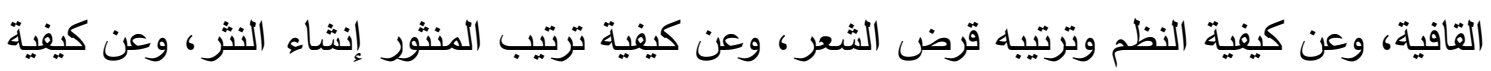
إيرادها في الكتابة علم الخط، والفرق بين العروض وقرض الشعر أنَّ العروض يتميز به الموزون من غيره، وقرض الشعر يعرف به كيفية إيراد الموزون والمقفى السالم من العيوب"((). وفيما يأتي تعريف موجز بجملة العلوم المتفق علي إدراجها في العربية والمختلف فيه:

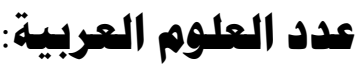

الأول: علم اللغة، ويُسمَّى بعلم متن اللغة، وهو العلم الذي يُعرف به أوضاع مفردات الكلام العربي من حيث موادها وجواهرها، وهي حروفها المخصوصة، "وغايته: الاحتراز عن الخطأ في فهم المعاني الوضعية،، والوقوف على ما يُفْهَمُ من كلام العرب"(؟)، ودواعي نشأته أنه لما فسدت وفي ملكة اللسان العربي في موضوعات الألفاظ "استُعمِل كثير من كلام العرب في غير موضوعه

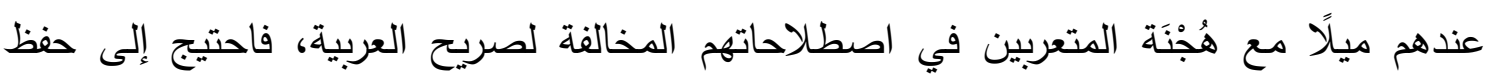
الموضوعات اللغوية بالكتاب والتدوين خشية الدُّروس وما ينشأ عنه من الجهل بالقرآن والحديث،

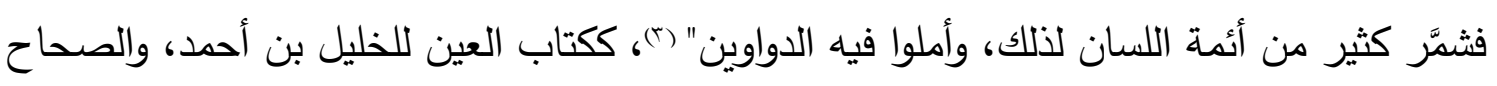
للجوهري، ولسان العرب لابن منظور .

الثاني: الصرف: ويقال له: علم التصريف، وهو: علم بأصول يعرف بها أحوال أبنية الكلمة التي ليست بإعراب ولا بناء، ومن فوائده: تحديد المعنى الصيغي للفظ، فإذا أردت أنْ تُحدّد معنى لفظ، تبحث عن معناه اللغوي في كتب الغريب والمعاجم، ثم عن معناه الصيغي في كتب الصرف؛ إذ لكل صيغة معنى يخصها، وكل حرف يُزاد على أصول الكلمة العربية لا بد أن يكون له معنى

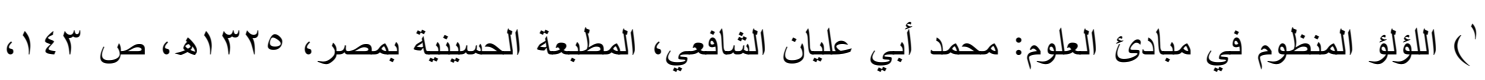

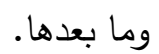

r مفتاح السعادة ومصباح السيادة في موضوعات العلم: أحمد بن مصطفى، الثهير بطاش كبري زاده، دار الكتب

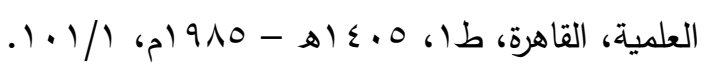

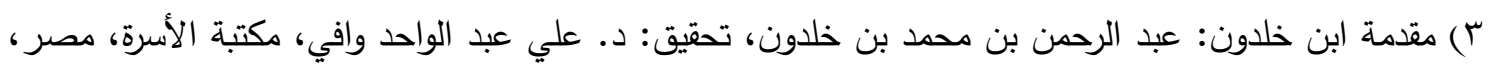

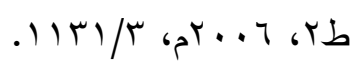


الثالث: الاثتقاق: علم بقواعد يعرف بها كيفية خروج الكلمات العربية بعضها من بعض لمناسبة بين المخرج والخارج بالأصالة والفرعية باعتبار جوهرها، وغايته: الاحتراز عن الخطأ في انتساب بعض الكلمات العربية إلى بعض، والفرق بينه وبين علمَي اللغة والتصريف أنَّ علم اللغة يبحث عن مدلولات جواهر الكلمات بخصوصها، وعلم الاشتقاق يبحث عن انتساب بعضها إلى بعض بحسب جواهرها، وعلم التصريف يبحث عن الانتساب بحسب هيئاتها، ويعلم من هذا الفرق بين هذه العلوم الثلاثة أن الاثتقاق كالبرزخ بين علمي اللغة والصرف، ولهذا استحسنوا تقديمه على الصرف، وتأخيره عن اللغة. وهذا العلم كثيرًا ما يذكر في كتب الصرف، وقلما يُدوّن مفردًا، إما لقلة قواعده، أو لاتصالهما في القواعد واشتراكهما في المبادي، حتى إن هذا من جملة البواعث على اتحادهما حيث لم يعرفوا أن الاتحاد في التدوين لا يستلزم الاتحاد في نفس الأمر، إذ كثيرًا ما يدون

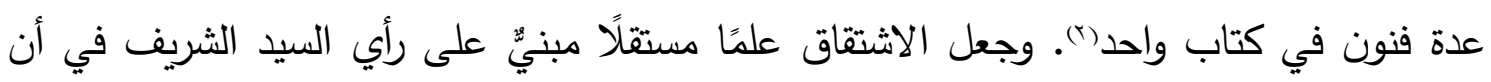
الاثتقاق علم مستقل بذاته، ويرى السعد أنه من تتمة علم الصرف، والحق مع السيد لتغاير موضوع كل منهما باعتبار الحيثية المعتبرة في موضوع كل منهما (ه). الرابع: النحو: علم بأصول تعرف به أحوال أواخر الكَلٍ إعرابًا وبناء، وفائدته: العصمة من

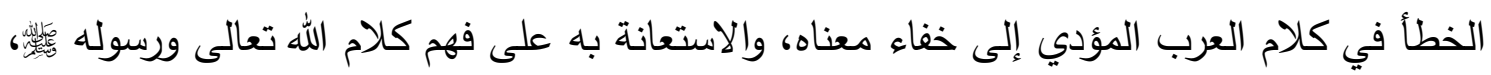
وعليه تتوقف صحة التركيب، وفهم أصل مراد المتكلم بخلاف غيره من علوم العربية(ع). الخامس: المعاني: علم يعرف به أحوال اللفظ العربي التي بها يطابق مقتضى الحال، وينحصر مقصوده في ثمانية أبواب: أحوال الإسناد الخبري، أحوال المسند إليه، أحوال المسند، أحوال متعلقات الفعل، القصر، الإنشاء، الفصل والوصل، الإيجاز والإطناب والمساواة، وفوائده كثيرة: منها: "معرفة دقائق العربية وأسرارها، وذلك أنَّ مَن تعلَّمه ثم سمع كلامًا من الكتاب والسنة

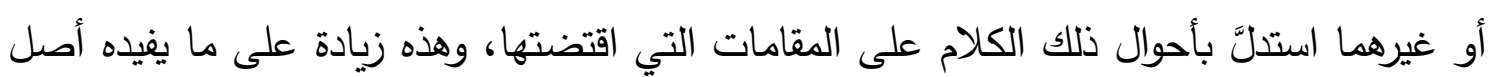
الكلام من ثبوت المسند للمسند إليه. ومنها: الاقتدار على إيراد الكلام مطابقًا لما يقتضيه المقام.

') ينظر: أثر الدرس اللغوي في فهم النص الثرعي: أ.د/ محمد المختار محمد المهدي، حولية كلية الدراسات

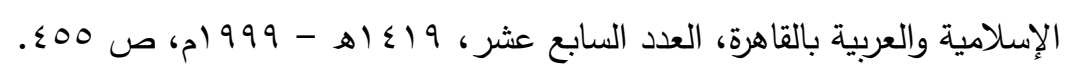

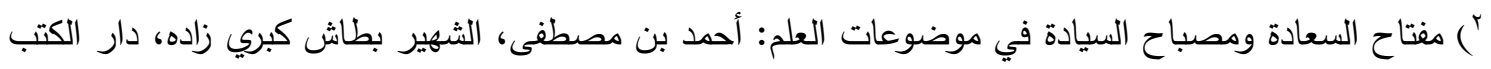

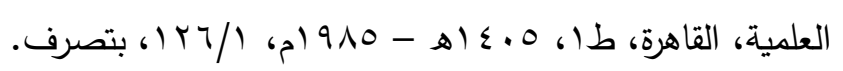

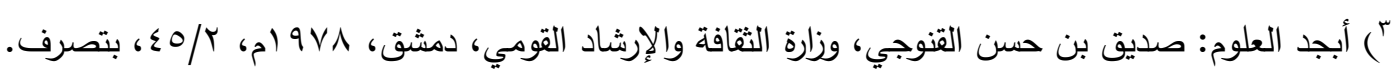

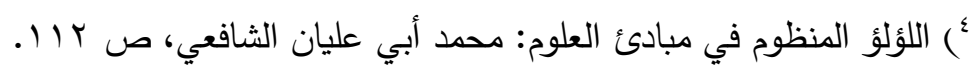




\section{حولية كلية الدعوة الإسلاهية بالقاهرة}

كعبالتكوين اللغوي للدعاة وأثره في تجديد الحطاب الديني

ومنها: معرفة الوجود التي نشأ عنها إعجاز القرآن للإنس والجان، وأن عجزهم عن معارضته لاشتماله على معاني ودقائق خارجة عن طاقة المخلوقات"( ().

وعلم المعاني شديد التداخل بعلم أصول الفقه، ينبه إلى ذلك بهاء الدين السبكي بقوله: "واعلم أن علمي أصول الفقه والمعاني في غاية التداخل؛ فإن الخبر والإنشاء اللذين يَتَكَلَُّ فيهما علم المعاني، هما موضوع غالب الأصول، وإن كان كل ما يتكلم عليه الأصولي من كون الأمر للوجوب، والنهي للتحريم، ومسائل الأخبار، والعموم والخصوص، والإطلاق والتقييد، والإجمال والتفصيل، والتراجيح، كلها ترجع إلى موضوع علم المعاني، وليس في أصول الفقه ما ينفرد به كلام الثارع عن غيره، إلا الحكم الثرعي والقياس وأشياء يسيرة"(().

السادس: البيان: علم يُعرَفُ به إيراد المعنى الواحد بطرق مختلفة في وضوح الدلالة عليه، أو يقال: هو علم يبحث فيه عن التشبيه والمجاز والكناية، "وفائدته منها: الاحتراز عن الخطأ في فهم المراد من الكلام حتى يتوصل بذلك إلى معرفة الأحكام الشرعية من كلام الله تعالى وكلام رسوله

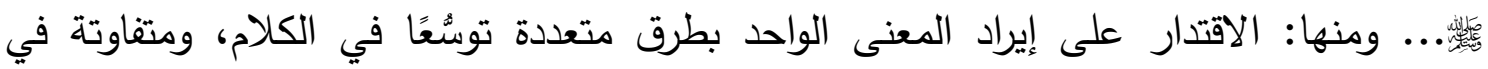
الوضوح؛ لأنه ربما يراد خطاب بعض السامعين بكلام لا يفهمه غيره، ولا يقتدر على ذلك كله إلا

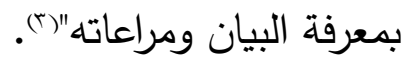

السابع: البليع: علم يُعْرَفُ به وجوه تحسين الكلام المطابق لمقتضى الحال، ولم يعد الزمخشري (علم البديع) علمًا مستقلً برأسه، بل جعله ذيلًا لعلمَي المعاني والبيان(ع)، والأوجه فيما يراه الدسوقي - أنْ يُعدَّ علمًا مستقلًا لتمايزه في موضوعه عن علمَي المعاني والبيان بالحيثية المعتبرة في موضوعات العلوم(0).

ويُطلق على جملة المعاني والبيان والبديع: علم البلاغة، ولها وظيفتان: معرفة دقائق العربية وأسرارها، والكشف عن وجوه الإعجاز النظمي للقرآن العظيم، فبها يُعرف أن القرآن

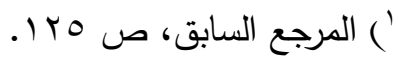

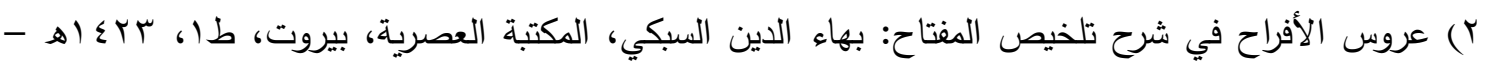
$. \Sigma V / 1,5 T \cdot T$

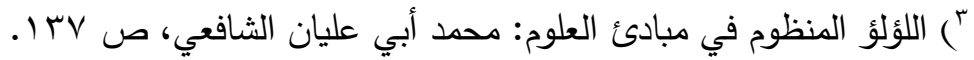
ع) ينظر : القسطاس في علم العروض: جار الله الزمخشري، تحقيق: د. فخر الدين قباوة، مكتبة المعارف، بيروت، طץ، · إ اهـ - 1919 (م، ص 17

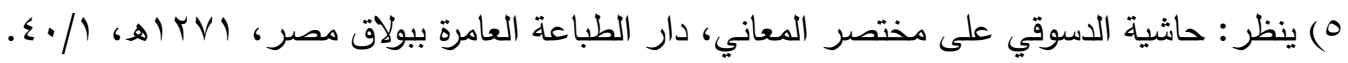




\section{حولية كلية الدعهوة الإسلاهية بالقاهرة}

كع التكوين اللغوي للدعاة وأثره في تجديد الخطاب الديني

مُعْجِزٌ (1)، ونبوةُ النبي إلا أن تلك المعجزات قامت في أوقات خاصة، وأحوال خاصة، وعلى أشخاص خاصـة، وبعضها نُقْلِ متواترًا، وبعضها نُقْلَ غير متواترِ، أما دلالة القرآن فهي عن معجزة عامة، عمت الثقلين، وبقيت بقاء العصرين(؟)

الثامن: العروض: وهو "علم يبحث فيه عن المركبات الموزونتة من حيث وزنها. واعلم أن أول من اخترع هذا الفن الإمام الخليل بن أحمد. ولا حاكم في هذه الصناعة إلا استقامة الطبع، وسلامة الذوق، فالذوق إن كان فطريًّا سليقيَّا فذالك، وإلا احتيج في اكتسابه إلى طول خدمة هذا الفن" (ه). التاسع: القوافي: "علم يبحث فيه عن تتاسب أعجاز الأبيات وعيوبها. وغرضه تحصيل ملكة إيراد الأبيات على أعجاز متناسبة، خالية عن العيوب التي يتنفر عنها الطبع السليم، على الوجه الذي اعتبره العرب، وغايته الاحتراز عن الخطأ فيه، ومباديه مقدمات حاصلة من تتبع أعجاز

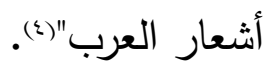

العاشر: الإنشاء: "علم يبحث فيه عن المنثور من حيث إنه بليغ وفصيح، ومشتمل على الآداب المعتبرة عندهم في العبارات المستحسنة، واللائقة بالمقام... ومباديه مأخوذة من تتبع الخطب والرسائل، بل لله استمداد من جميع العلوم، سيما الحكمة العملية، والعلوم الثرعية، وسير الكمل، ووصايا العقلاء، وغير ذلك من الأمور الغير المتناهية"(ه).

الحادي عشر: قرض الشعر، ويقال له: القريض، والنَّظٌْ، وهو "علم باحث عن أحوال الكلمات

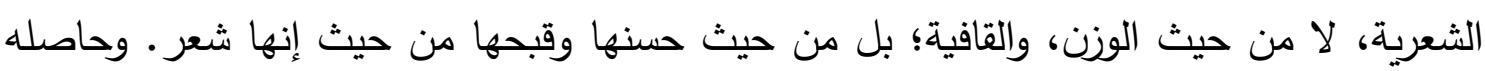
تتبع أحوال خاصة بالثعر من حيث الحسن والقبح، والجواز والامتتاع، وأمثالها" (ج).

() ينظر : تلخيص المفتاح: محمد بن عبد الرحمن القزويني، مكتبة البشرى، باكستان، طا، ابـ اهـ - . ( • بم، ص ص 0. r) إعجاز القرآن: القاضي أبو بكر الباقلاني، مطبعة مصطفى البابي الحلبي وأولاده بمصر، طا، 91 باهـ ـ

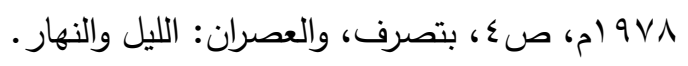
r كثف الظنون عن أسامي الكتب والفنون: حاجي خليفة مصطفى بن عبد الله، المشهور بكاتب جلبي، دار إحياء

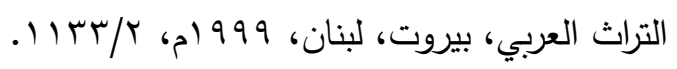

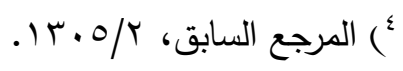

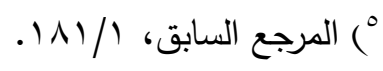

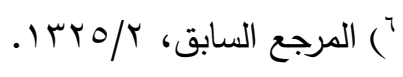




\section{حولية كلية الدعهوة الإسلاهية بالقاهرة}

كئالتكوين اللغوي للدعاة وأثره في تجديد الحطاب الديني

الثاني عشر: الخط: ويقال له: فن الرسم والخط، وإملاء الخط، والكتابة، وهو: "علم بكيفية تصوير الألفاظ بحروف الهجاء وبالأحوال التي تعرضها في الكتابة" (1)، "وهذا العلم من حيث نقش الحروف بالآلة من أنواع الخط، ومن حيث دلالتها على الألفاظ من فروع علم العربية"(؟). الثالث عشر: علم التاريخ: وهو علم يبين أسماء مشاهير الناس، وأزمنتهم، وأمكنتهج، وأعمارهم، وأعمالهم، ولعل للتاريخ الإسلامي خصوصية أوجبت عده من العلوم العربية، ولذلك أَبدله بعضهم بالمحاضرات(")، يقول العلامة الدسوقي عن كون علم التاريخ من العربية: "والحق أنه ليس منه؛ لأن التاريخ ليس خاصَّا بلغة العرب، فالأَولى إبداله بعلم التجويد"(().

الرابع عشر: علم المحاضرات: يعنى بالنوادر في الفنون المختلفة التي يحاضر بها بعض الناس بعضًا في مسامراتهم(ْ)، أو هو علم جُمِعَ فيه ما يطيب بذكره المجلس، ويتعجب منه الحاضرون بسبب ما فيه من الغرابة من جهة تركيبه أو من جهة معناه، أو بسبب كونه حكاية أمر غريب. ويكون بعض ما جمع فيه في العقايد، وبعضها في الأحكام العملية، وبعضها من المواعظ، وبعضها مُزَاحًا يضحك منه. ومن الكتب فيه: كتاب (ربيع الأبرار ونصوص الأخبار) للزمخشري، و كليلة ودمنة) لعبد الله بن المقفع(1).

أولًا: لعلم الأدب استعمالان: استعمال بالمعنى الأعم وهو المرادف للعلوم العربية، وبالمعنى الأخص ويراد به: "حفظ أشعار العرب وأخبارها، والأخذ من كل علم بطَرَف، أي الأخذ من علوم اللسان أو العلوم الثرعية من حيث متونها فقط، ويُقصد منه الإجادة في فني المنظوم والمنثور على أساليب اللسان العربي ومناحيهم، وأصول هذا الفن وأركانه أربعة دواوين، وهي: أدب الكاتب لابن قتيبة، وكتاب الكامل للمبرد، وكتاب البيان والتبيين للجاحظ، وكتاب النوادر لأبي علي القالي، وما

') دستور العلماء (جامع العلوم في اصطلاحات الفنون): القاضي عبد النبي بن عبد الرسول، عرب عباراته

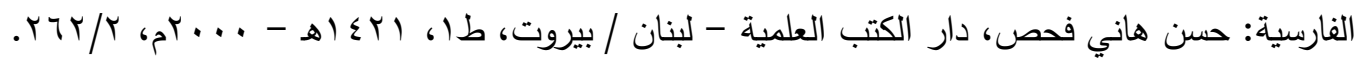

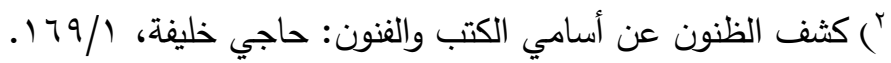

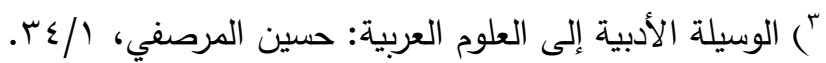

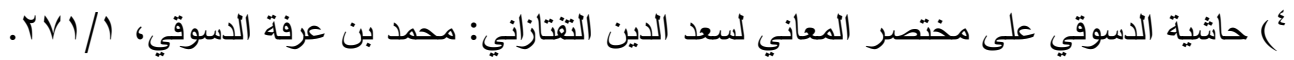

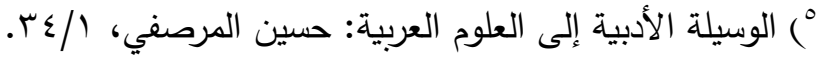
") ترتيب العلوم: محمد بن أبي بكر المرعشي، الثهير بساجقلي زاده، تحقيق: محمد بن إسماعيل، دار البثائر

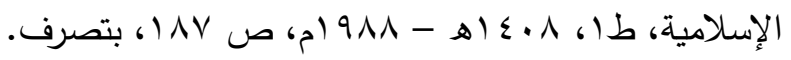




\section{حولية كلية الدعهوة الإسلاهية بالقاهرة}

\section{كعَالتكوين اللغوي للدعاة وأثره في تجديد الحطاب الديني}

$$
\text { سوى هذه الأربعة فتبعٌ لها وفروعٌ عنها" (1). }
$$

ثانيًا: إن قلت: أين كانت هذه العلوم في زمن الصحابة؟ أجيب بأنَّ الصحابة كانوا يعرفون العربية بالسليقة والممارسة، وما استُحْدِث إنما هو الاصطلاحات، والمصطلحات لا تدخلها البِدَع، يقول بهاء الدين السبكي في طالعة كتابه في البلاغة: "إن قلت: أين كان هذا العلم في زمن الصحابة الذين يعرفون أسرار العربية، وانكشف لهم أوجه الإعجاز؟ قلت: كان مركوزًا في

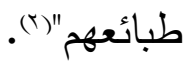

فالصحابة كانوا يمارسون العربية، ويتخرجون الأحكام من النصوص، غاية الأمر أن هذه الممارسات العملية من الصحاية وتابعيهم استقرأها العلماء ودوّنوها فكان تدوين العلوم، فهل قولنا:

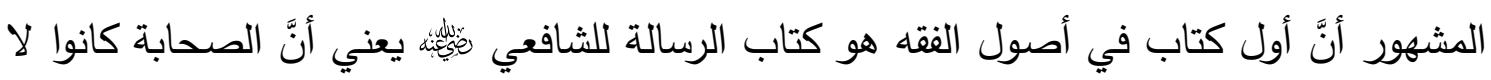
يعرفون دلائل ومضامين علم أصول الفقه؟ بالطبع لا، فالمستحدَث هو المصطلحات، والمصطلحات لا توصف بالبدع؛ لأنها ما وُضِعَت إلا لتذل على معنى خاص، إذ الاصطلاح إما لغوي أو عرفي، والعرفي إما عام أو خاص، وكلٌ هذا يدل على معانٍ معينة.

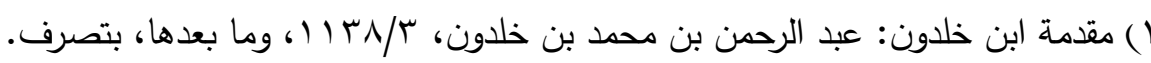

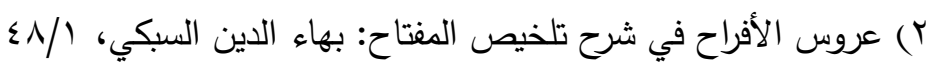




\section{الاطلب الثاني \\ الارتباط بين اللغة العربية والهوية الإسلاهية}

(اللفظ، والمعنى، والفكر، والدين) أربعة ألفاظ مترابطة، فالمعنى هو ما يُعنى ويُقصد من

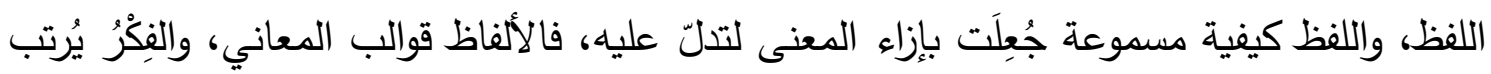

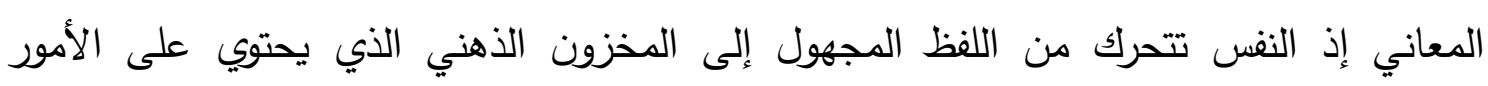

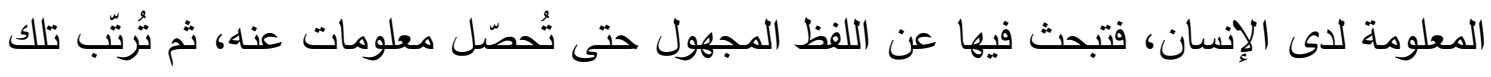

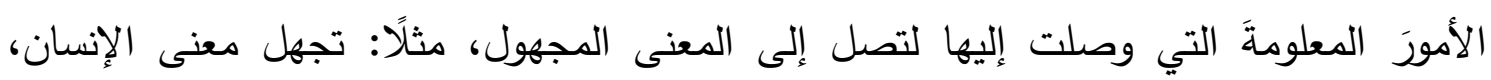

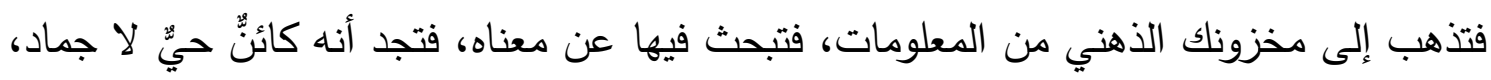

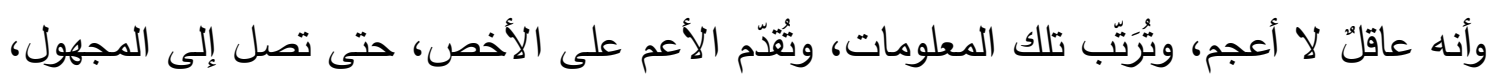

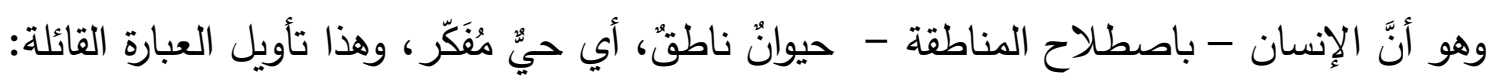

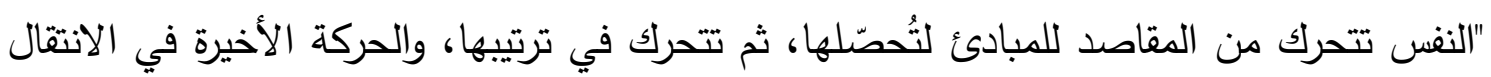

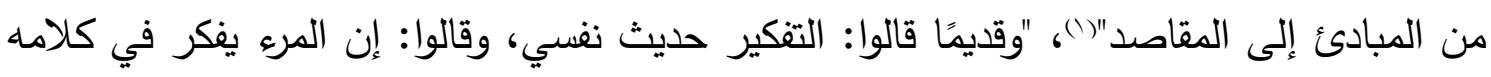

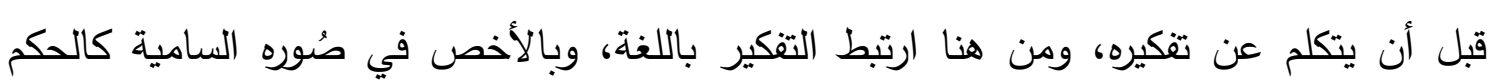

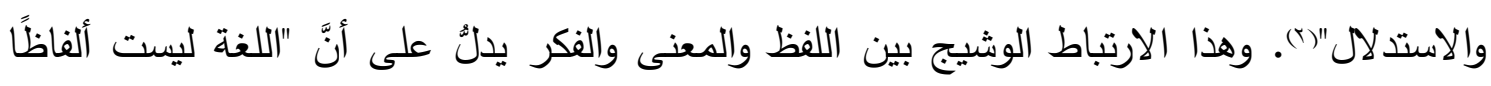

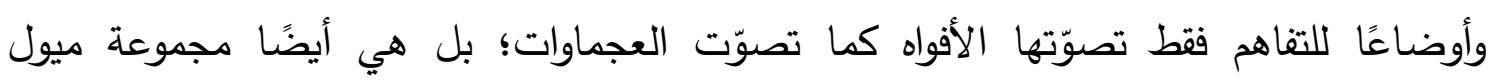

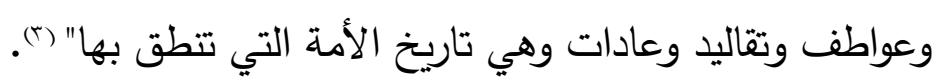

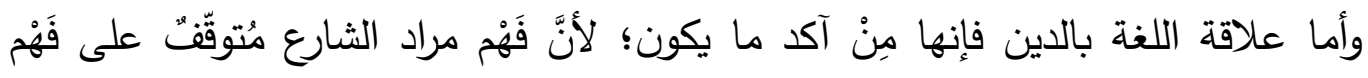

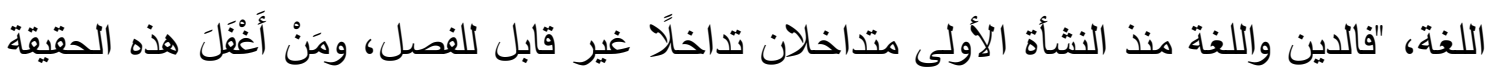

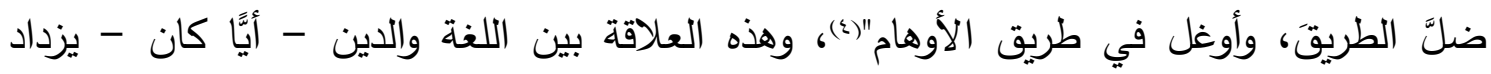
ترابطها في الدين الإسلامي؛ ذلك "أن القرآن نزل بلسان العرب على ولى الجملة، فَطَلَبُ فهمِه إنما يكون

') حاشية الأمير على شرح عبد السلام لجوهرة التوحيد للإمام اللقاني، مكتبة ذخائر الوراقين، القاهرة، طا،

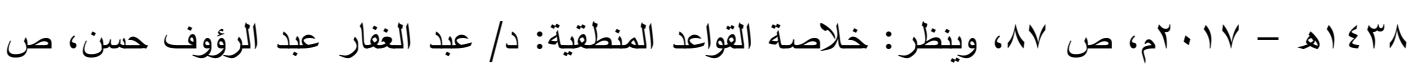

.7. 619

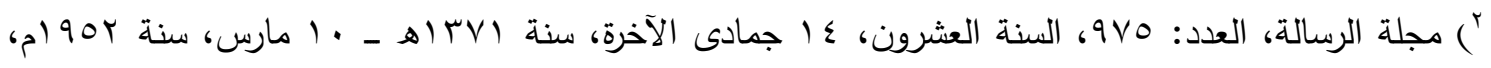

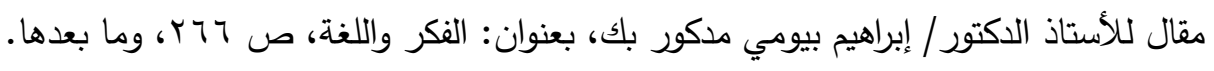

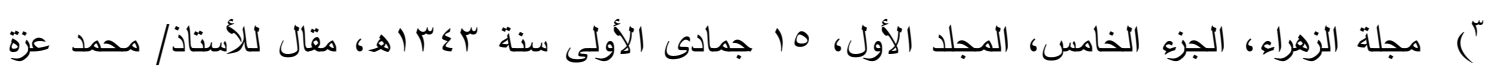

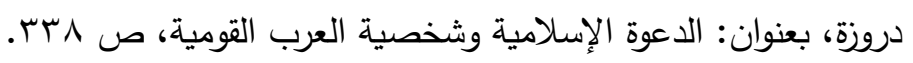

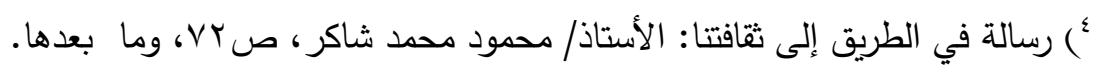




\section{حولية كلية الدعهوة الإسلاهية بالقاهرة}

كبع التكوين اللغوي للدعاة وأثره في تجديد الحطاب الديني

من هذا الطريق خاصة" (1)، ومن قواعد تفسير النصوص أنه "لا بد في فَهْم الشريعة من اتباع معهود الأُمّيني، وهم العرب الذين نزل القرآن بلسانهم، فإنْ كان للعرب في لسانهم عرف مستمر فلا يصح العدول عنه في فهم الثريعة، وإن لم يكن ثَّ عرف فلا يصح أنْ يجرى في فهمها على ما لا

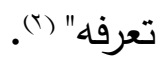

ولندرك العلاقة التأثُّرية بين اللغة والقرآن، وأيهما أثنَّ في الآخر : اللغة أثَّرت في القرآن أم

القرآن أثَّر في اللغة، ننظر إلى البيئة الجغرافية للغة العربية قبل الإسلام وبعده، "فاللغة العربية قبل القرآن والسنة لم تكن تدور إلا في نطاق محدود بين العراق والحجاز شرقًا وغربًا، وتخوم الروم وبلاد اليمن شمالًا وجنوبًا، فإنَّ تَنَقُّلَ العرب كان محدودًا بهذه الجزيرة العربية، ولم يكن لها أثر يذكر في البلاد المجاورة كالفرس والروم والأحباش، ولكن الوثبة الإسلامية ساقت هذه اللغة إلى بلاد الصين شرقًا، والمحيط الأطلسي غربًا، في مدة لا تتجاوز القرن الأول الهجري بمقتضى الفتوح والدعوة الإسلامية، وهو انتشار قوي في سرعته، لم يعهد له نظير في أي لغة أخرى، بالإضافة إلى لـى لإنى ظاهرة التأليف في العلوم المختلفة التي كانت عاملًا قويًا في انتشار اللغة العربية"(ه). فالإسلام هو الذي نشر العربية، ولولاه لانْدَرَت وانْمَحَتْ كما انمحى غيرها من لغات، إذ اللغةُ كائنٌ حيُّ، يعتريها ما يعتري الإنسان من ضعف وقوة، وذبول وفناء، إلا إذا وُجِدَ ما يمنع ذهابها، وهذا المانع توفّر للعربية، وعَصَمَها من الفناء وإنْ أصابها الوهن والخمول في عصور مختلفة، وهو القرآن الكريم، فَبِهِ بقيت اللغةُ العربيةُ قرونًا متعاقبة، وبهـ انتشرت في الآفاق، ومنهـ انطلقت الدعوة الإسلامية، وأثمَرَت اتساع أرض الإسلام بالفتوحات الإسلامية، ولأجله ظهر التأليف في العلوم المختلفة الذي بدأ أول ما بدأ لخدمة القرآن الكريم، والسنة المطهرة، وهو الجامع الذي الإسماني ينطوي تحت لوائه المسلمون، وبتعبير الأديب إيراهيم اليازجي: هو الجامعة الجنسية(؛)، ويؤكد ذلك الرافعي بقوله: "فلولا الترآن وأسراره البيانية ما اجتمع العرب على لغته، ولو لم يجتمعوا لتبرَّلت لغاتهم بالاختلاط الذي وقع ولم يكن منه بدُ، حتى تنتقض الفطرةُ وتختبل الطباع، ثم يكون مَصِيرُ هذه اللغات إلى العَفَاء لا محالة، إذ لا يخلُفهم عليها إلا من هو أشدُّ منهم اختلاطًا وأكثرُ فسادًا،

() الموافقات في أصول الشريعة: أبو إسحاق الثاطبي، علَّق عليه: محمد عبد الله دراز، مكتبة الأسرة، مصر،

$$
\begin{aligned}
& \text { طr، } 7 \text {. . Tr، }
\end{aligned}
$$

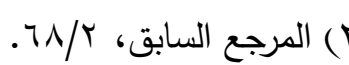

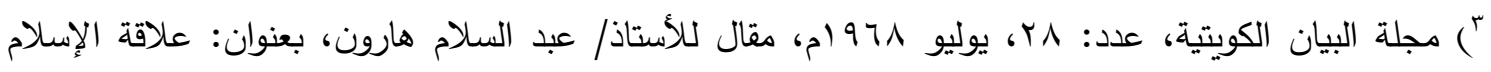

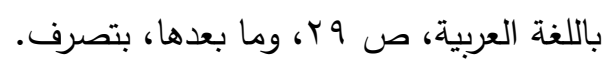

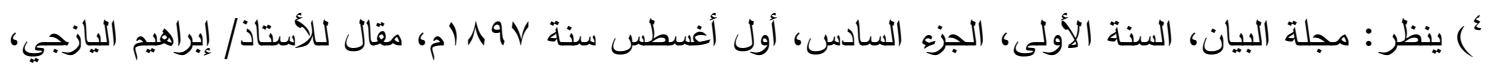
بعنوان: اللغة والعصر (تابع)، ص ror r. r. 


\section{حولية كلية الدعهوة الإسلاهية بالقاهرة}

كئالتكوين اللغوي للدعاة وأثره في تجديد الحطاب الديني

وهكذا يتسلسل الأمرُ حتى تَنْتَبْهِمَ العربيةُ فلا تُبِينُ وهي أفصحُ اللغات، إلا بضَرْبٍ من إشارة الآثار ، وتنزل منزلة هذا الهيرُغليف الذي قَبَرَهُ المصريون في الأحجار، وأحيتْهُ هذه الأحجار "(1). وتجاوَزَ أتثر الإسلامِ من كونه نَشَرَ العربية وزاد من زحفها إلى كونه أثَّرَ في غيرها من لغات إما بالقضاء عليها وإما بالاقتباس من لغته، "فلقد بلغ من السلطان الديني للإسلام أن يمحو اللغة القبطية في مصر، التي كانت تطورًا من اللغة المصرية القديمة الحضارة، في زمن وجيز، وأن يقضي كذلك على لغة القرطاجيين وغيرهم في شمالي أفريقية، وعلى لغة النَّبط في شمالي العراق، وأن يقلص ظل اللغة الرومية من الأطراف الثمالية لبلاد الثام، كما استطاع أن يغيرّ وجه اللغة الفارسية بمنحها أكثر من • r \% من ألفاظها، وكذلك أمكن هذا السلطان أن يترك في جنوبي إيطاليا وصقلية وفي تركيا وأسبانيا وجنوب فرنسا أثرًا ظاهرًا دامغًا تتفاوت درجاته في القلة

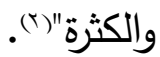

فإنْ قلت: القرآن مسبوقٌ بالعربية، فما الضير في القول بأنَّ العربية هي التي نشرت

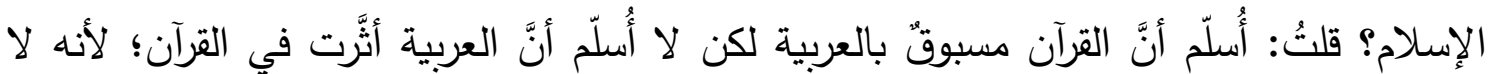
يلزم من قِدَم الثيء زمانيًا تأثيره في غيره، ولأنَّ القرآن وحيُّ من عند الله، فانتشاره وتأثيره في غيره من هذا القبيل، وفي ذلك يقول الأستاذ/ عبد السلام هارون: "أما القول بأن اللغة العربية كانت سببًا في انتشار الإسلام فقول يحيطه التحفظ، فالإسلام إنما انتشر بمبادئه وأصوله الفطرية السليمة، يدل على ذلك هذه الملايين المسلمة التي لا تعرف من العربية قليلً ولا كثيرًا، وهذه الآلاف التي تعتنق الدين الإسلامي من الأوروبيين والأمريكيين والإفريقيين والأسيويين لا عن وراثة ورثوها، ولا عن أمة وجدوا عليها آباءهم، بل بالقراءة والتدبر في لغاتهم الأجنبية التي يطلعون بها على مبادئ هذا الدين الحنيف، على حين لا نجد هذه الأعداد في المعاصرين من معتنقي الديانات الأخرى إلا بالإرغام السياسي أو التبشيري المتطرف"(ه).

وعلى الجملة، لو افترضنا عدم وجود القرآن: فما الحبل الذي يعتصم به العرب، وقد توفرت

لايهم دواعي الثقاق والافتراق؟! لا شيء سوى القرآن، فهو الرابطة الحقيقية التي ينضم تحت لوائها المسلمون، ولو افترضنا عدم وجود القرآن، أبقي للعربية وجود؟ كلا، بل لَحِقَها ما لَحِقَ اللغات

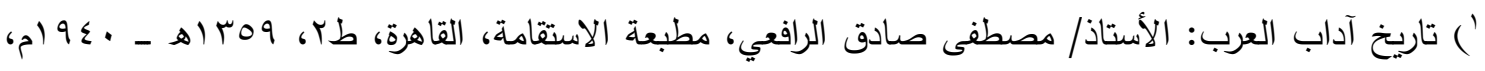
$.7 \mathrm{~V} / \mathrm{r}$

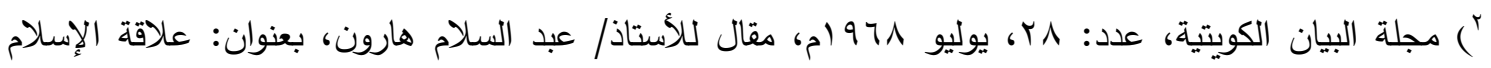

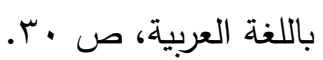

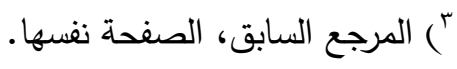




\section{حولية كلية الدعهوة الإسلاهية بالقاهرة}

كع التكوين اللغوي للدعاة وأثره في تجديد الخطاب الديني

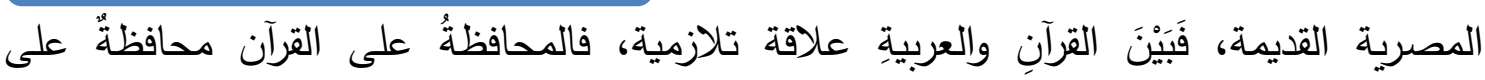
العربية، والمحافظةٌ على العربية محافظةٌ على القرآن، وبذلك تدرك أنَّ القضاء على القرآن لا يكون بِجَمْعِ المصاحف وإخفائها عن المسلمين، بل بصدّهم عن العربية، فالصَّادُّ عن العربية صادٌّ عن سبيل الله.

فإنْ قلت: اتضحت العلاقة بين اللغة والفكر والدين، لكن أهناك علاقة بين اللغة والثقافة؟ أجيب بجواب جملي وجواب تفصيلي: أما الأول فإنَّ اللغة هي وِعَاء المعارف جميعًا، والثقافة هي ثمرة المعارف جميًا. والثاني بأنَّ بين الدين واللغة والثقافة تداخلًا غير قابل للفصل؛ ذلك وأنَّ الثقافة تدل على طورين متكاملين: الطور الأول: إسار التسخير، وجِمَاعُه كل ما يتلقاه الإنسان عن أبويه وأهله ومُعلّميه حتى يصبح قادرًا على أنْ يستقل بنفسه.

الطور الثاني: طلاقة التفكير، وهو مُنْبَتِقُ عن الطور السابق، وذلك حين يبدأ العقل عمله في الاستقلال بنفسه، ويستبد بتقليب النظر والمباحثة وممارسة التفكير والتتقيب والفحص ومعالجة التعبير عن الرأي الذي هو نتاج مزاولة العقل لعمله، فعندئذ تتكون النواة الجديدة لما يمكن أنْ تيُسمَّى (ثقافةة).

والطريق إلى تحقيق ذلك هو اللغة والمعارف الأُوَل التي كانت في طورها الأول مصبوغة بصبغة الدين لا محالة، وعلى قدر شمول الدين لشؤون حياة الإنسان، وعلى قدر ما يُحصّل منه الناشِئ، يكون أثرُهُ بالِغَ العمق في لغته التي يفكّر بها، وفي معارفه التي ينبني عليها كل ما يوجبه عمل العقل من التفكير والنظر والاستدلال (1). بَانَنَ مما سبق، أنه لا يمكن الفصل بين اللغة والفكر والثقافة والدين، وأنَّ انبهارَ بعضِ المسلمين بالحضارة الغريبة، وتقديمَ لسانها على اللسان العربي، ليس إلا تعبيرًا عن انفصامٍ في

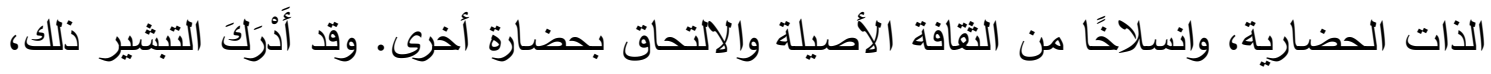

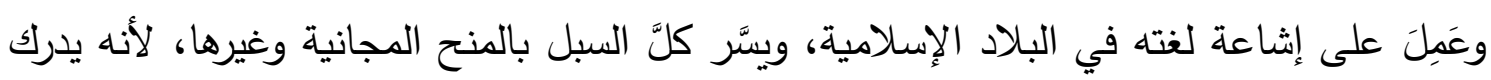

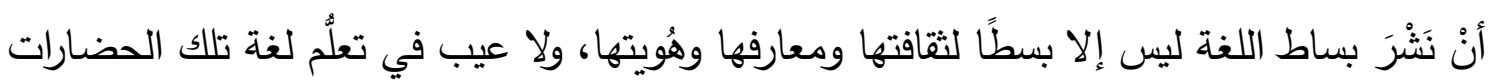
إنْ كنَّا نُرْرِكُ ما يُحاق بنا، ويُدبَّرَ لنا.

') رسالة في الطريق إلى ثقافتتا: الأستاذ/ محمود محمد شاكر ، ص بV، وما بعدها، ملخصًا. 


\section{المبمث الثاني}

\section{الواقع اللغوي للدعاة}

ثمة ارتباط بين الازدهار اللغوي والخطابي، فالعناية بالخطابة من ثمار العناية بالعربية،

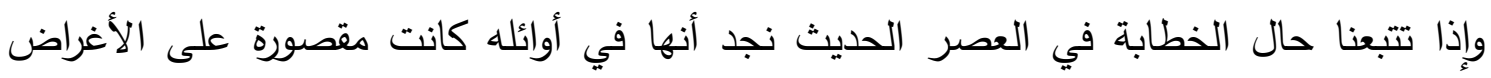

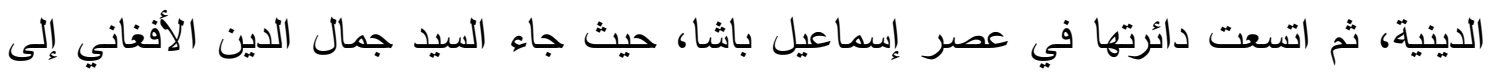

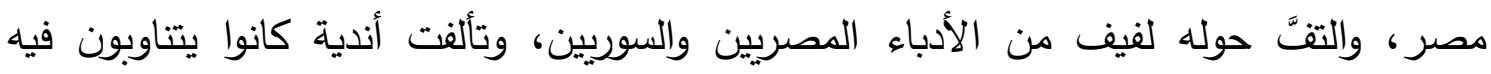

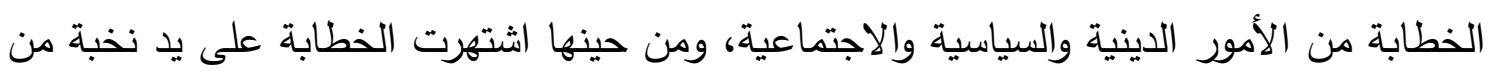

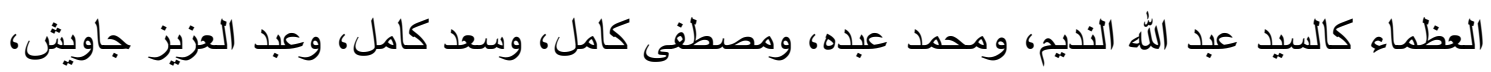

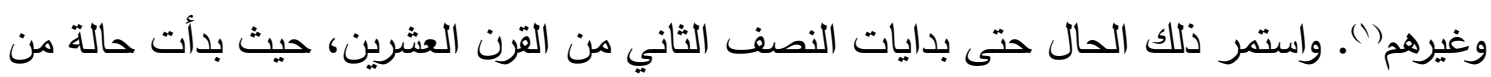
الضعف اللغوي والركود المعرفي، وتجلَّى ذلك في مظاهر مختلفة شملت الدعاة وغيرهم:

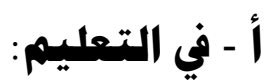

في الددارس والجامعات ـ وهي صفوة المجتمع ـ قلَّ من يتكلم الفصحى من المحاضرِين،

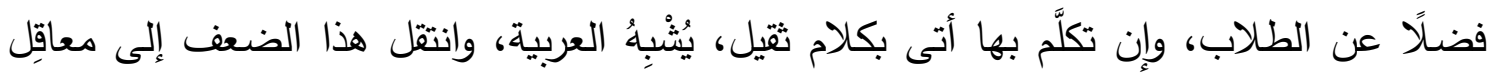

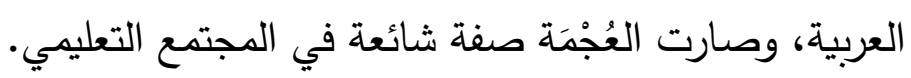

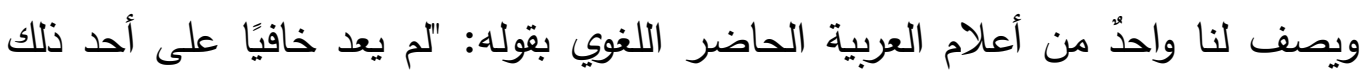

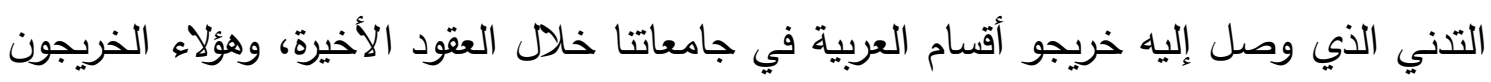

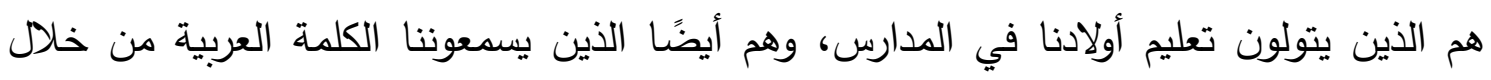

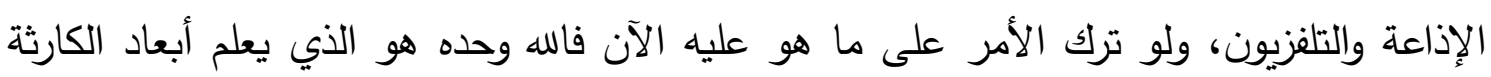

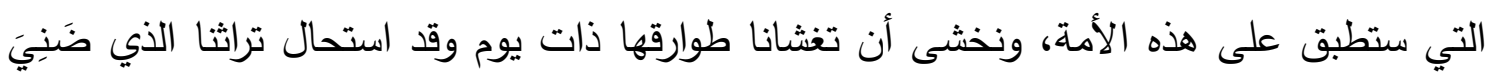

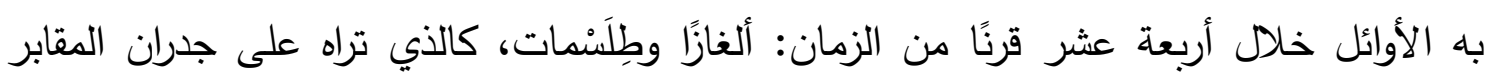
والمعابد ولفائف البردي، رموزًا قديمة تخفى على جمهرة الناس، ولا يعقلها إلا العالمون" (ه).

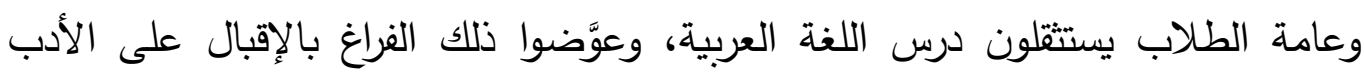

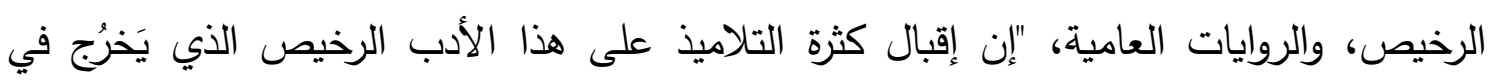

') ينظر : جواهر الأدب في أدبيات وإنثاء لغة العرب: السيد أحمد الهاشمي، مكتبة الثقافة الدينية، القاهرة، طلr،

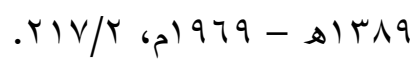

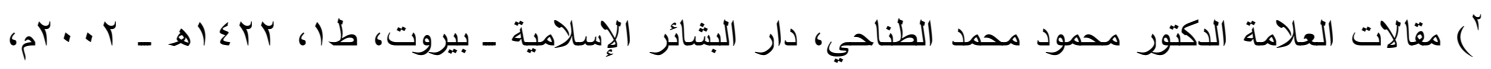

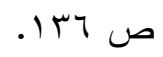


كأك التكوين اللغوي للدعاة وأثره في تجديد الخطاب الديني

العامية حينًا، وفي تلك العربية المنكَّرة الثائهة أحيانًا، وتهافتهم عليه، وافتنانهخ به، وأخذ الأقلام بمحاكاته وتَرسُمه، إنما هو أثنر من آثار ذلك البَرَم والاستثقال لدروس العربية وآدابها في معاهدنا

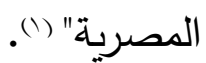

ب - في الإعلام:

تُستعمل الفصحى في بعض البرامج والنشرات الإخبارية، وبعض الأعمال الدينية والتاريخية، وعدا ذلك فباللهجة العامية، ولكل دولة لهجتها. ولم يقتصر الأمر على استعمال اللهجة العامية في الإعلام، بل صوَّرت بعضُ الأعمالِ الفنية اللغة العربية مُدرّسَ اللغة العربية في صورة رجل متخلف ظلامي، عاكف بين جدران متهدّمة، يُطالِع كتبًا متآكِلة، يقرأ فيها (إنَّ وأخواتها)،

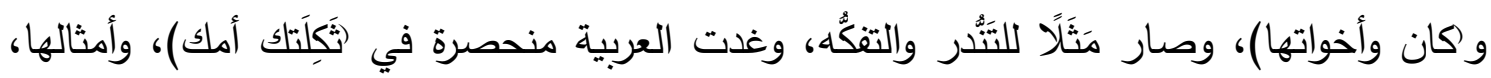

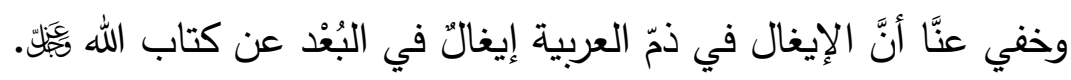

\section{الإظاهر العامهة للضعف اللغوي:}

من المظاهر العامة للضعف اللغوي:

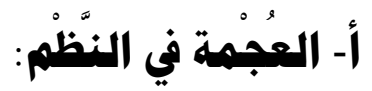

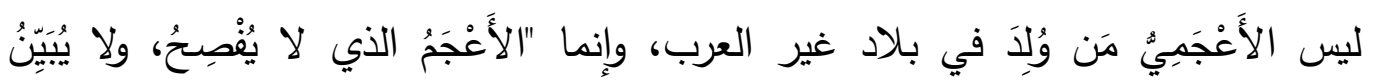
كلامَه، وإِنْ كان عَرَبَّ النَّسب"(ب)، والعربية لا تلحصر في أن تُخْرِج لسانك في حرف الثاء والذال والظاء، ولا في أنْ تلتزم بالمرفوعات والمنصوبات والمخفوضات، ولا في أنْ تلوي شِدْقَك للتَّفَصُح، نعم الالتزام بمخارج الحروف، والمعرَب والمبني من العربية، إلا أنه جزءٌ منها، وتضييعُ الأجزاءٍ الأخرى يُخْرِج الكلامَ عن معهود العرب في الخطاب، ومن معهودهم أنَّ البلاغة يُوصَفُ بها الكلام والمتكلم، فتقول: كلام بليخ، ومتكلم بليغ، ولا يُوصَفُ بها المفرد، فلا تقول: كلمة بليغة. ومفهوم ذلك أنَّ لِنَظَْ الكَلِم، وإقامة التراكيب طريقةً خاصَّةً عند العرب، ويظهر ذلك بالنظر إلى كلامنا في عصرنا الراهن: تراكيب غير معهودة، ولا مستعمَلة عند العرب، كلامٌ قَذَفَهُ اللسان دون رابط ولا جامِع ولا فكر .

أما النَّظْ عند العرب فمأخوذ من نظم حبات اللؤلؤُ في العِقْد، وهو الخيط الذي يُنْظِم فيه الخرز، فكما أنَّ كل حبة بجوار أختها في تراصٍٍ وتتاسب، فكذا الكلام حيث "تؤلف كلماته مرتبة المعاني، متتاسقة الدلالات، على حسب ما يقتضيه العقل، لا تواليها في النطق، وضمّ بعضها إلى

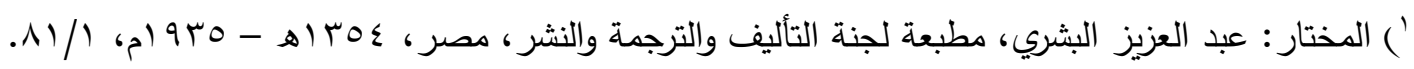

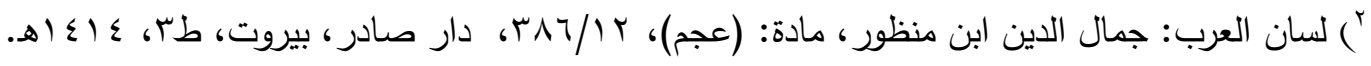




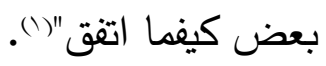

ولافتقاد ذاك المسلك، يقول الدكتور/ عبد الله الطيب: "وقد كادت اللغة العربية نفسها تذهب الآن، وهذه الأشياء التي يزعم لها أنها لغة عربية فصيحة، إنما هي أمشاج مختلفة لا تمت إليها بصلة واشجة وثيقة، ولا تصلح وسيلة لدرس ميراثنا من الحضارة الإسلامية العظيم، ولا تصلح وسيلة لدرس القرآن، ومعرفة معجزته وعلومه، والانتفاع بموعظته وهداه والثفاء الذي فيه، ولدرس السنة وما معها من أصول وفقه وتوحيد وبركة ونور"(().

\section{ب- استبلاب الشرف بالاغغات الأجنبية:}

شاع في المجتمع العربي أنَّ التكلم بالعربية دليلُ على الجمود والتخلُف، وأنَّ تضمين المتكلم بعض الكلمات الأجنبية أمارة على التتوير والتقدُّم، مع أنه قد لا يحسن من الإنجليزية سوى بضع كلمات! والخطر في ذلك هو الانهزام اللغوي، والشعور بأن لغته غير جديرة في التخاطب والتحادث، ويدفعه هذا الشعور إلى التظلُّل بلغة أجنبية، والاستلحاق بها، وإنْ انساق وراء شعوره فيسعى للحصول على درجة علمية من دولة أجنبية، حتى في لغته وعقيدته، ويعود إلى وطنه رافعًا هامته، مُصَعِّاً خده، ويقول: لقد حصلت على الدكتوراه في اللغة العربية؟ فتسأله: من أين حصلت عليها؟ فيجيك: من أمريكا، ويجيب آخر: من بريطانيا! وهذا الثعور موجود من سنوات منصرمة، ولكنه في تصاعد مَخُوف، "وإذا كان الذين يتكلمون بهذه اللغة أشتانًا متفرقين بين أمم سبقتهم في حلبة تنازع البقاء، كما هو ثابت بالعيان، فلا بدع إن كان مصير هذه اللغة إلى ما نراهُ من الانحطاط حتى صار أهلها يستكفون من التكلم بها، ولا يعولون في قراءة العلوم التي نبغ فيها أسلافهم إلا على لغة أجنبية، فالذي يؤثر التععق في علم الثربعة مثًاً لا يُعدّ بارعًا مستحقًّا للشهادة إلا متى درس هذا العلم في اللغة الفرنسوية، وكفى بذلك برهانًا على انحطاط الأمة العربية في هذا العصر "(r).

\section{جـ - الاستهانة بالآثار الأدبية:}

ينكر أستاذ العربية محمود شاكر على العرب تقصيرهم في حق لغتهم، مؤكدًا أنهم تفردوا من بين جميع الأمم المتعلمة بِِِمَةٍ ميزتهم عن غيرهم، وهي أنهح الأمة التي تسيء إلى لغتها، ولا

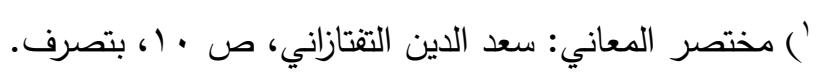

ץ) مجلة الدوحة، عدد: • 1، (191/م، ، مقالة للدكتور/ عبد الله الطيب، بعنوان: ضرورة الرجوع إلى القرآن الكريم

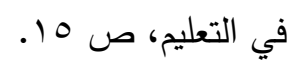

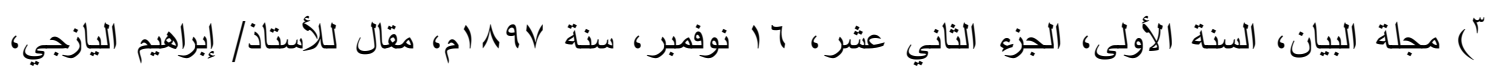

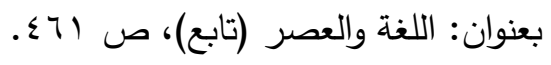




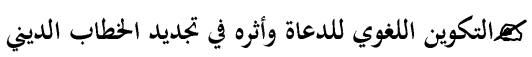

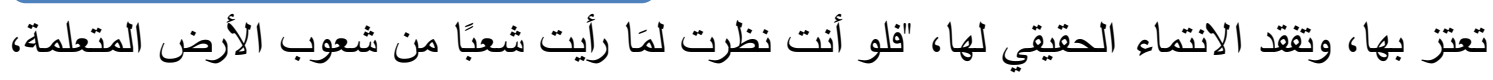
يفعل بلغته ما نفعل نحن من التجاهل للآثار الأدبية وقلة الاحتفال بتزويد الناشئ بمادتها التي تحفظها لتكون أبدًا على مدّ الذاكرة وفي طلب اللسان، ولو أنت سألت أي متعلم من أهل الأمم الأخرى أن يُسمِكك من روائع شعر أمته ونثرها وحديث بلغائها لاحتفل لك بالكثير الذي تظن معهد أنه إنما أعدَّ لك الجواب لعلمِه أنك قد أعددت له السؤال، فلو أنت جئت بعد ذلك إلى أحد المثقفين المكثرين المتنفّخين من المتعمين عندنا وسألته مثل ذلك لنَحا إليك بصره، فأتأر (1) النظر ، فابتسم، فضحك، فاستهزأ بك، فولاك ظهره، فمضى يعجب من غفلتك وحماقتك، وقلة عقلك "(r). وأجاد الأستاذ شاكر في وصف موقف المثقف المتنفخ، وصوَّر بدقة بالغة ردّ فعل ذلك المثقف إزاء مَنْ يتكلم بالعربية الفصحى الذي ينتهي إلى استحقار كلّ مَنْ يتكلم بالفصحى، ورميه بالقِدَم والتخلُّف، وليس ذلك إلا لأن اللغة العربية تتحدر إلى زمن غابر متطاول القِدَد، وكأن قِدَم

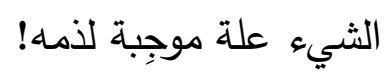

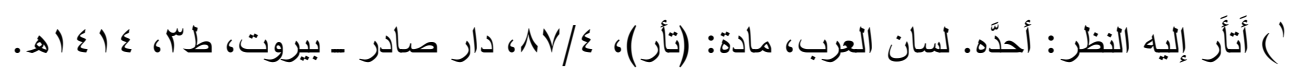

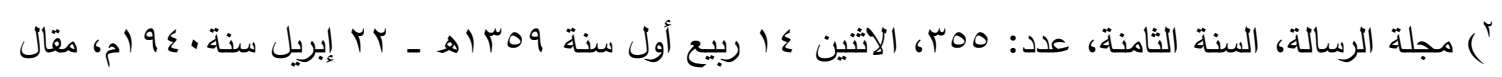

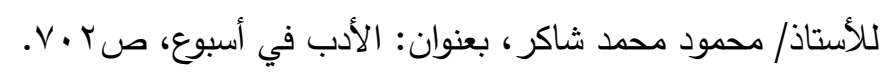


المبحث الثالث

\section{هموضات الازدهار اللغوي للادعاة}

دراسة أسباب الثيء من أوائل طرق معالجته، ودقةُ تثخيصِ المرض مؤثّر في علاجه،

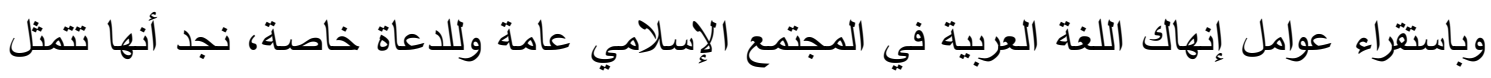
في عوامل داخلية، وأخرى خارجية:

\section{المطاب الأول \\ العواهل الخارجية}

تتمثل في الاستشراق، والتبثير، والاستعمار، وهذه الثلاثة فئات متكاملة: فالاستثراق

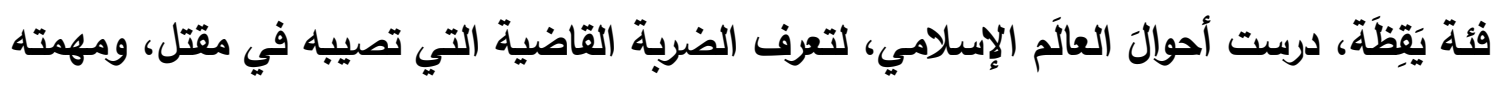

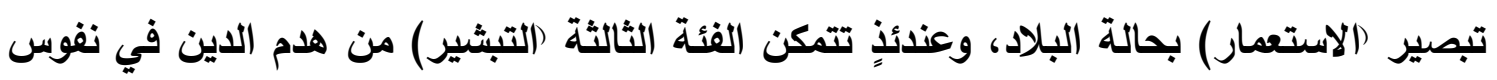

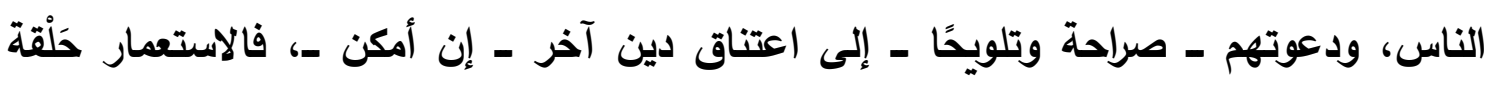

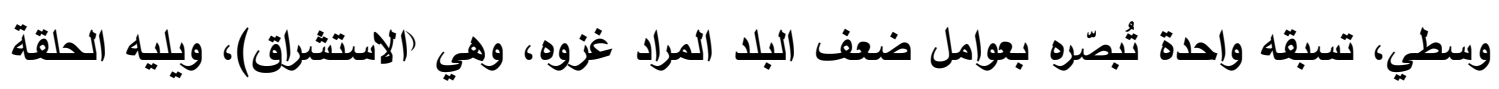

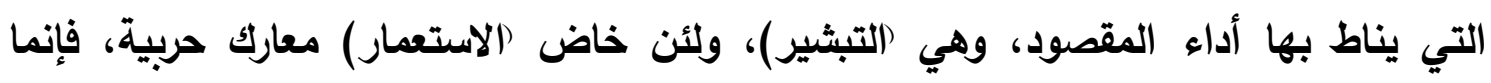
يخوضها ليتمكن (التبشير) من مزاولة عمله(1).

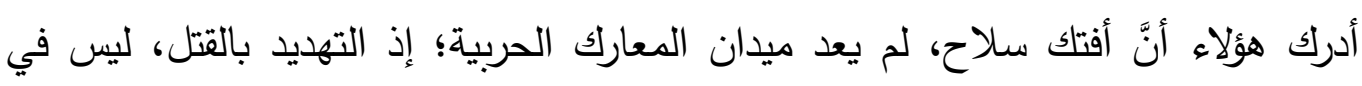

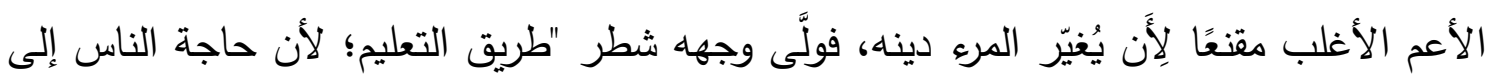

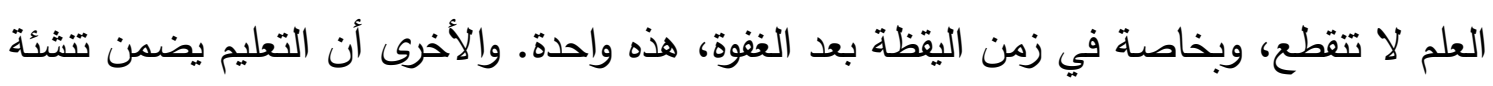

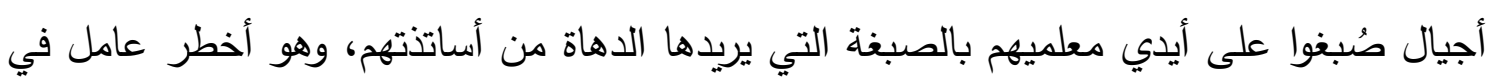

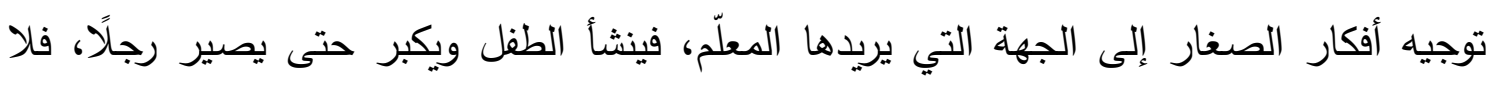

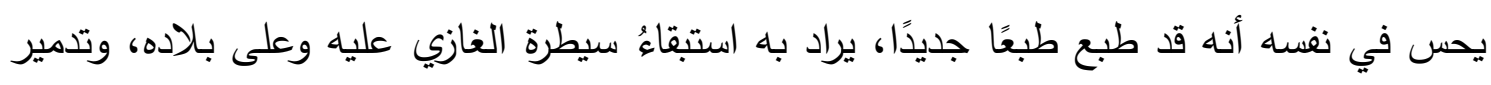

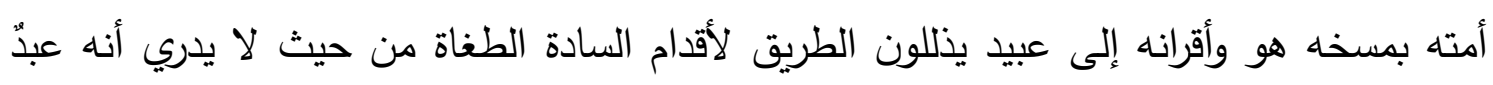



') ينظر : المساجلات النكرية بين الأستاذ محمود شاكر ومعاصريه: د. عبد الغفار عبد الرؤف حسن، الدكتبة

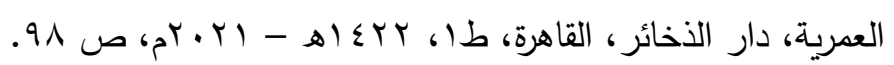

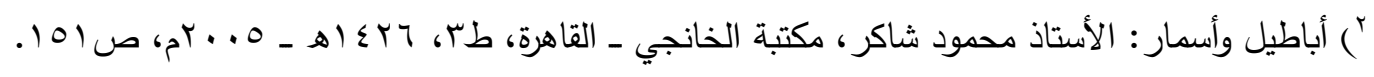




\section{حولية كلية الدعوة الإسلاهية بالقاهرة}

\section{كعبالتكوين اللغوي للدعاة وأثره في تجديد الحطاب الديني}

من الحتم المقطوع به أن تكون سياسة الغزو الأوربي موجهة إلى مصر قبل كل مكان في هذا

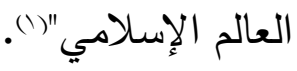

وبعد أن أيقن الاستشراق أن الوسيلة الأسرع للقضاء على العالم الإسلامي واختراق ثقافته،

هي تغريب تعليمه، وأن المكان الأمثل لانطلاقهم هو مصر، بحكم أنها للعالم الإسلامي منبِت التعليم وعَلَمه "عَمِلَ في إصرار على إضعاف اللغة العربية، والتهوين من أمرها، وتحقير شأن القائمين عليها، وأثار حولها الزوابع والأعاصير ، بأنها لغة معقدة، عقبة في طريق رقي مصر ، وأن من الخير أن يتخذوا العامية لسانًا، ولم يقل لنا أي عامية نتكلم ... وهي دعوة سار على خطاها قلة من المثقفين، بعضهم مخدوع، والآخرون رأوا أنَّ السير وراء المستعمر ينتهي بصاحبه في نهاية المطاف إلى وظيفة مريحة أو منصب مرموق"(1).

فإنْ قلتَ: ذَهَبَ الاستعمار عنَّا بجيشه، فمن الكسل والخُنُوع نسبة تقصيرنا إليه. قلتُ ا ـ أُسلّم بأننا مقصّرون في حق لغتنا، وأننا لو كنا في حالة قوةٍ معرفيةٍ ولغويةٍ ما كان للاستعمار أثر، إلا أنَّا نعيش في حالة مرضية، وهو ما أَسْمَاهُ مالك بن نبي بالقابلية لكلاستعمار .

r. القوة اللغوية تستدعي العمل على جبهتين، جبهة داخلية بنشر اللغة، وجبهة خارجية عن طريق رصد المحاولات الخارجية التي تريد اختراق لغتنا، وصدّها، والتحذير منها، والتقصير

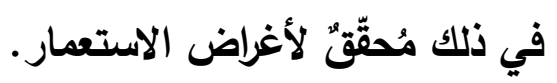

r. الاستعمار وإن رحل عنا بجيشه لكن له ذيول وأتباع، يعمل بعضها معه، وبعضها الآخر لا يعمل معه غير أنه متفق معه في غايته وأفكاره، فالمنحرِف قد يتفق معه غيره، ويعمل مثل عمله، وإن لم يحدث بينها تلاقٍ وتشاهد. ع ـ الضعف الداخلي وفقدان المناعة الذاتية مجلبة ومكثرة لعوامل الضعف، والضعف الاخلي لا ينافي وجود عوامل خارجية تعمل على إضعاف اللغة العربية. آثار الاستعمار في حاضر اللغة العربية: رحل الاستعمار عن البلاد الإسلامية بجيشه، لا بفكره، وفيما يلي أذكر بعض آثاره في اللغة

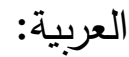

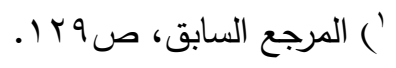
ץ مجلة أدب ونقد، العدد الثاني، السنة الأولى، فبراير عـ9 (ام، مقال للدكتور / الطاهر أحمد مكي، بعنوان: مقالات الاستعمار والتخريب الثقافي، ص ب؟ب، وما بعدها. 
ا - انتشار المدارس الأجنبية في البلاد الإسلاهية:

يتسارع بعض الأغنياء والطامحين إلى إلحاق أولادهم بالمدارس والجامعات الأجنبية في

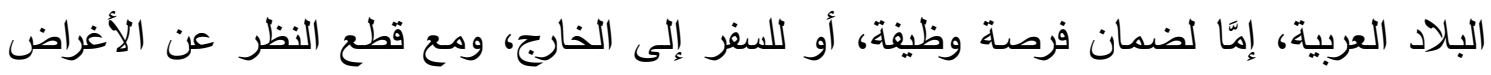

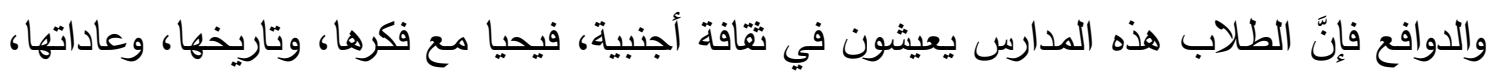

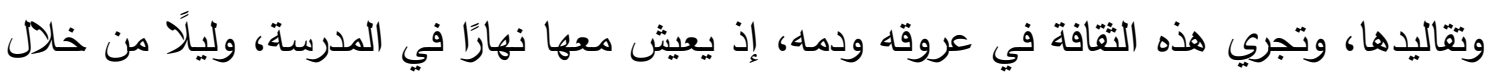

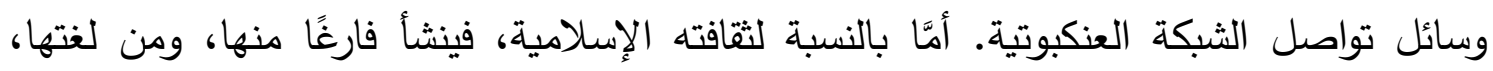

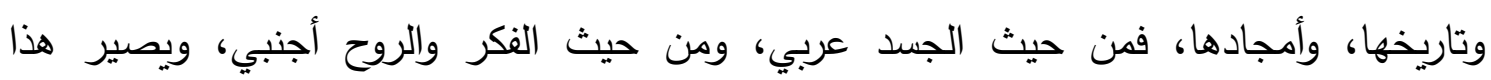

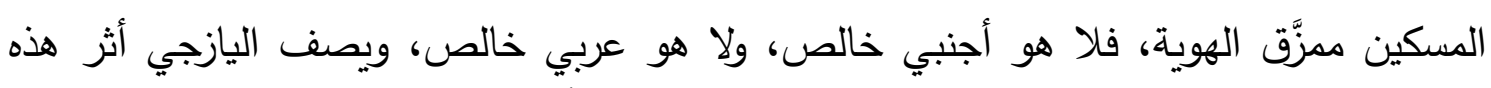

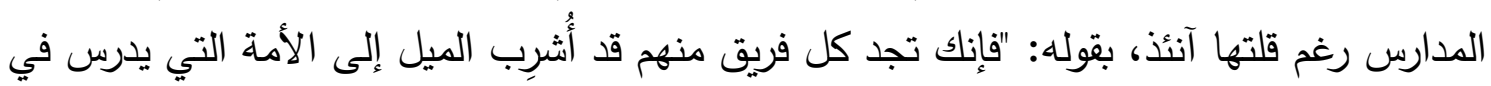

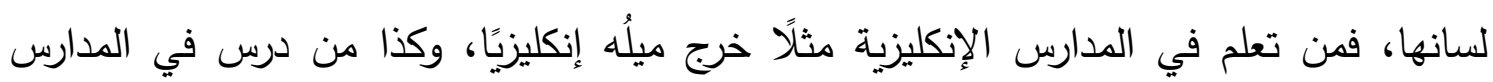
الفرنسوية أو الطليانية أو غيرها، حتى تراهُ يباهي برجال تلك الأمة، ويتجح بأخبار ملوكها وكبرائها

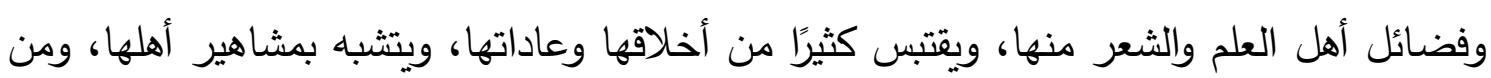

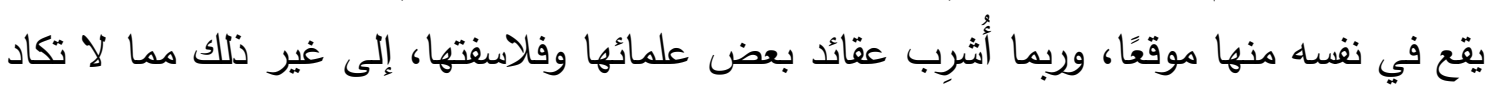

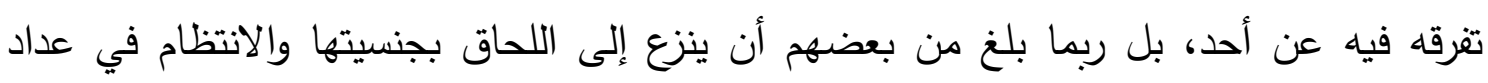

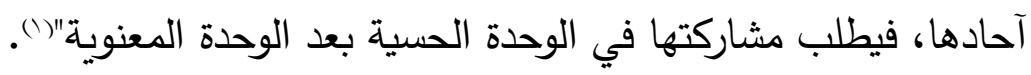

ولا نُمانِع من تعلُّم اللغات الأجنبية، واكتساب معارفها، ولكنَّا ضد تدمير الهُوية الإسلامية

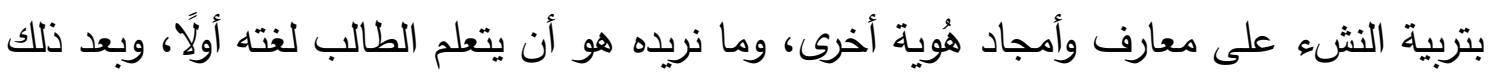
يتعلَّم ما شاء من لغات أخرى.

\section{r - بهور دعوات هدأهة لأتباعه:}

وجَّه بعضُ أنصارِ الاستعمار ومُحبِّه اتهامات للغة العربية، كاتِهامها بأنها لغة دينية

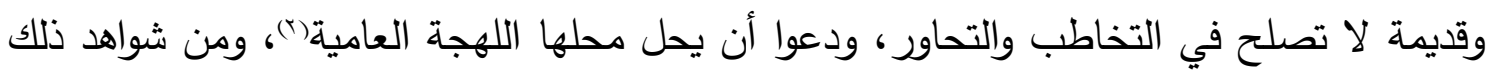

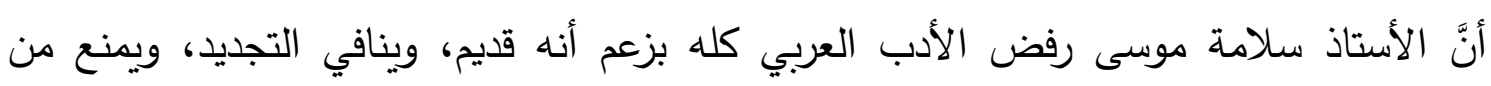

') مجلة البيان، أول أغسطس سنة و9 (1م، مقال للأستاذ/ إبراهيم اليازجي، بعنوان: اللغة والعصر (تابع)، ص ror

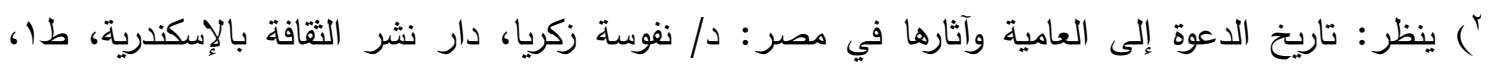

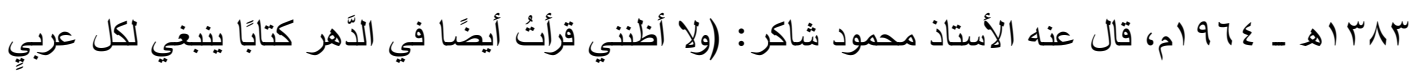
وكل مسلحٍ أن يقرأه من ألفه إلى يائه يُضارِعُ هذا الكتاب). 


\section{هولية كلية الدعموة الإسلاهية بالقاهرة}

كبع التكوين اللغوي للدعاة وأثره في تجديد الحطاب الديني

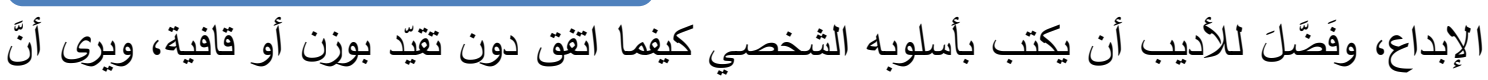

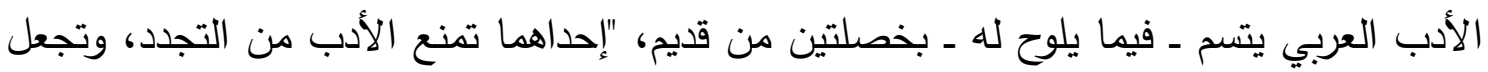

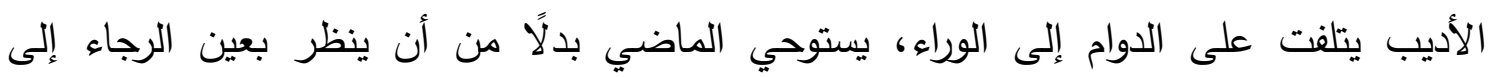

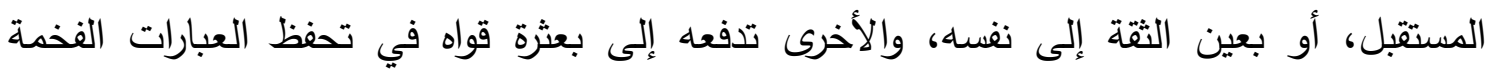

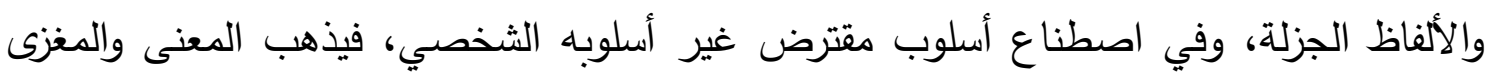
فذاء لبهرجة سخيفة توذي القارئ والكاتب معًا" (1).

وهذا الكلام أقامه الأستاذ سلامة موسى على مغالطة كبرى، وهي القِدَم والجِدَّة، فَذَّم القديمَ؛

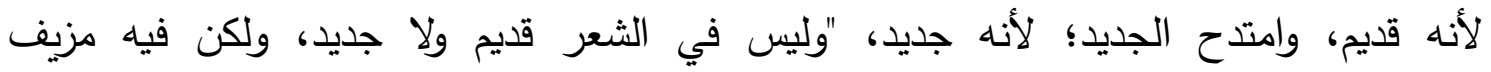

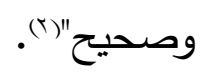

وقد لاحظ أديب العربية/ مصطفى صادق الرافعي أنَّ تلك الفئة التي سافرت إلى فرنسا

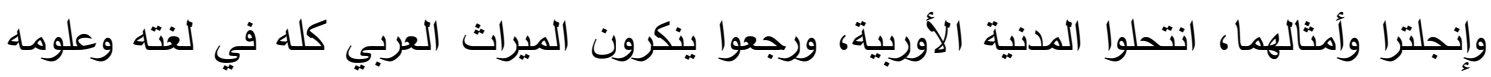

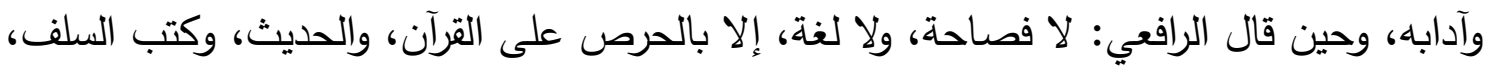

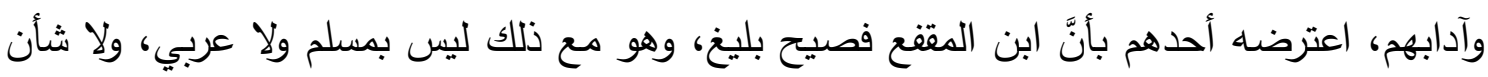
له بالحديث، ولا بالقرآن، ولا بالدين، فعلق الرافعي بقوله: "ولا أدري والله كيف يفهم هذا لها وأمثاله؟!

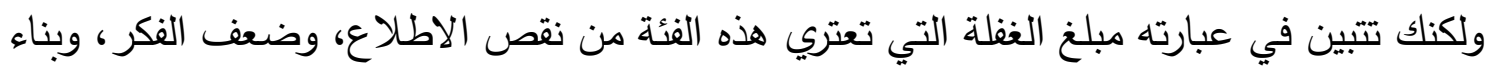

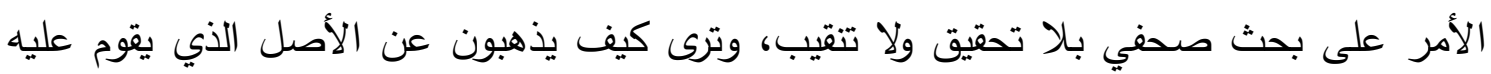

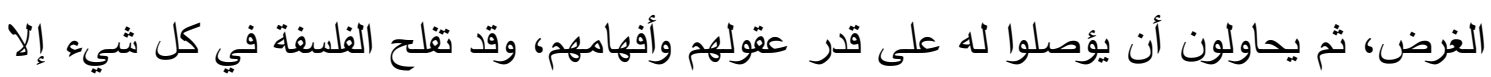

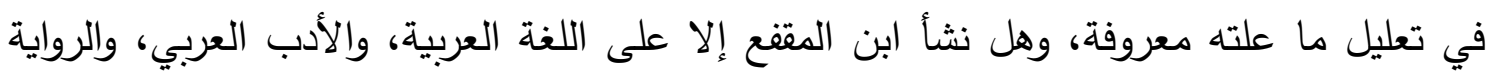

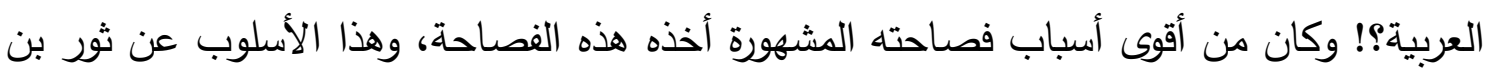

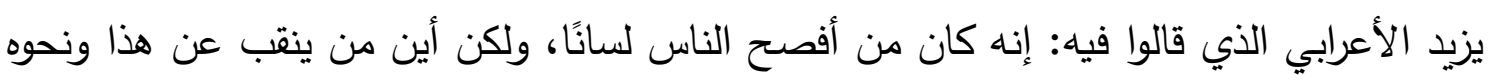
في تلك الجماعة، أو يتوهمه فيقف على حدّه" (ن).

ولو تفحَّصت حال هؤلاء الذََّّين للعربية لوجدت ميراث أغلبهح من العربية التي يرمونها

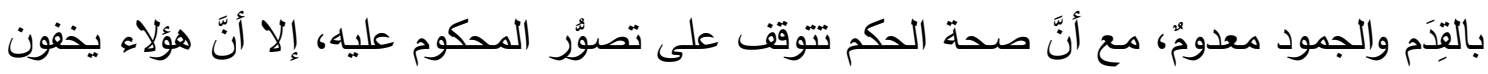

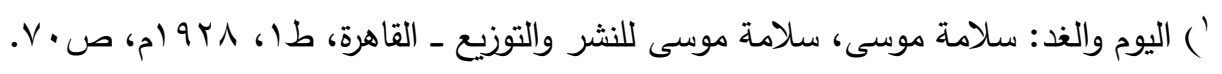

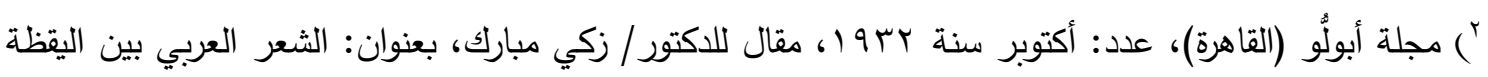

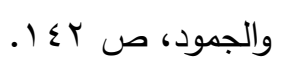

"ام تحت راية القرآن: الأستاذ/ مصطفى صادق الرافعي، صحح أصوله تلميذه الأستاذ/ محدد سعيد العريان، دار

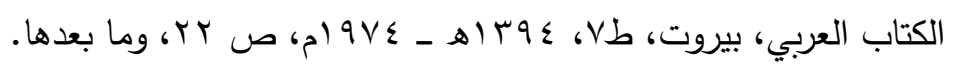


كع التكوين اللغوي للدعاة وأثره في تجديد الخطاب الديني

فراغهح بمصطلحات التجديد، والإبداع، والحداثة، وأمثال هذه الغوامض، يقول الرافعي: "وأشهد ما لماين

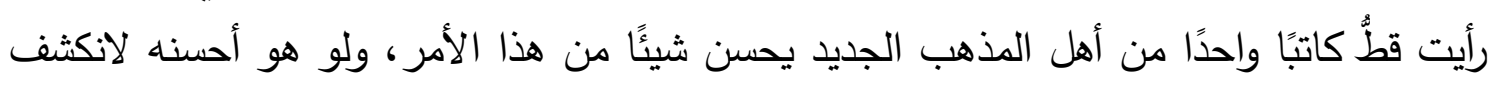
له من إحسانه ما لا يُبقي عنده شكًا في إبطال هذا المذهب وتوهيته، ولذا تراهم يعتلون لمذهبهم الجديد بالفن والمنطق والفكر وبكل شيء إلا الفصاحة، وإذا فصُحُوا جاءوا بالكلام الفج الثقيل، والمجازات المستوخِمة، والاستعارات الباردة، والتشبيهات المجنونة، والعبارات الطويلة المضطربة التي تقع من النفس كما تقع الكرة المنفوخة من الأرض لا تزال تتبو عن موضع إلى موضع حتى

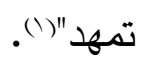

والحاصل أنَّ الاستعمار استبدل الحروب العسكرية بالحروب الثقافية، وعمادُ الثقافةِ اللغة،

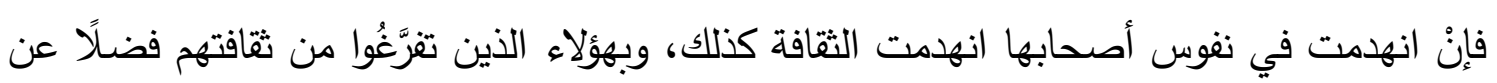
لغتهم حارب الاستعمار الثقافة الإسلامية ولغتها. 


\section{الاملب الثاني}

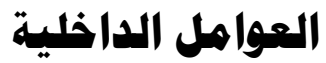

وتتمثل في العوامل التي ارتكبها أبناء العربية المسؤولون عن تعليمها، والحفاظ على سلامتها، ومن أهم تلك العوامل: العل

\section{ا - إهمال التوجه العام للغة العربية:}

يُنظر إلى التوجُهه العام باعتبارين:

الأول: على مستوى الأمم: فقد قرَّر ابن خلدون أنَّ المغلوب مُولعٌ أبدًا بقليد الغالب، وذلك

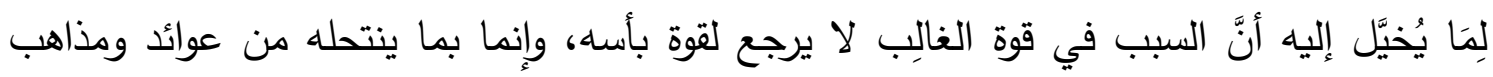

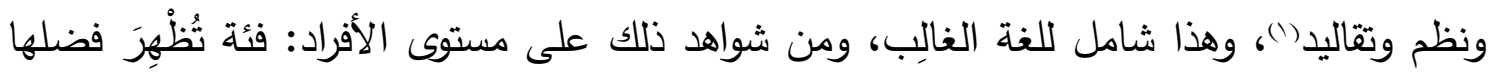

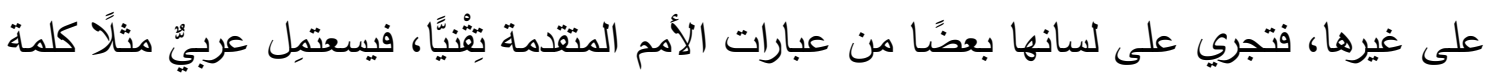

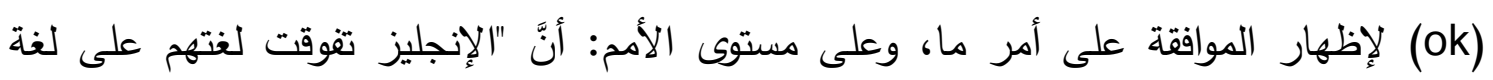

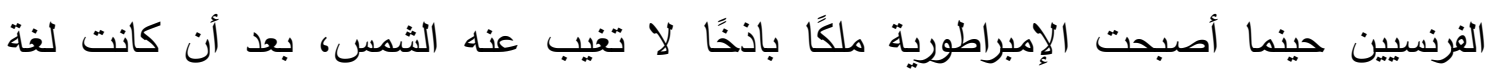

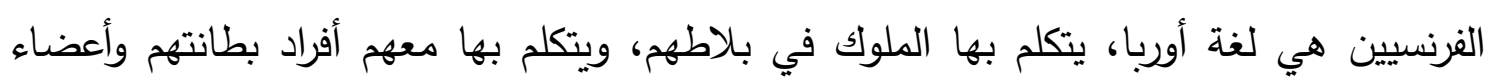

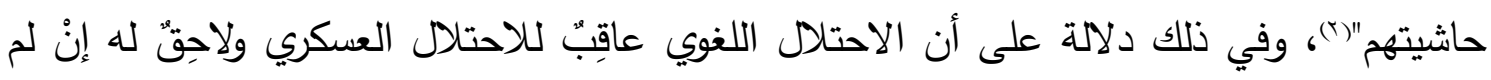

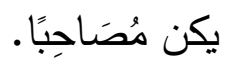

الثاني: على مستوى الأمة الواحدة: قاضي العيان يحكم بأنَّ قائد الدولة، أيَّا كانت، متى

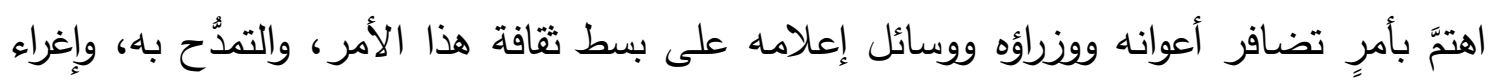

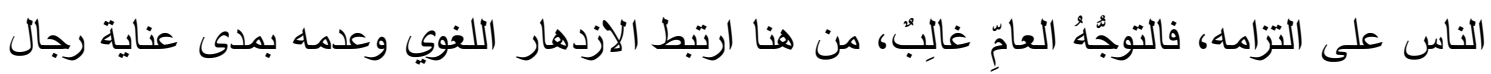

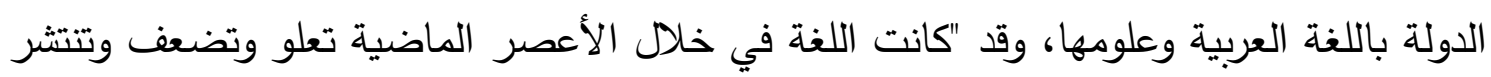

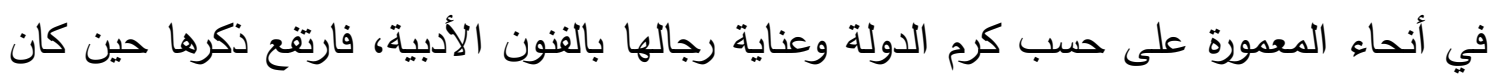

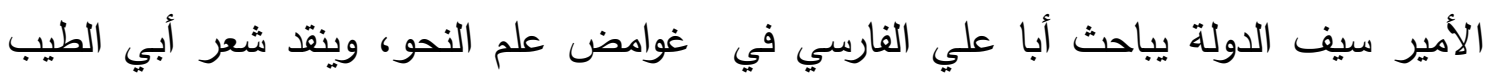

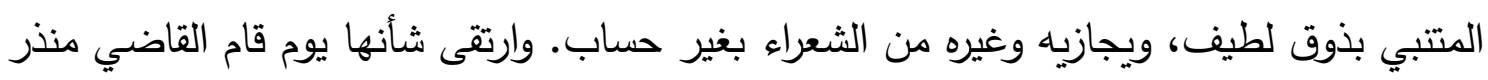

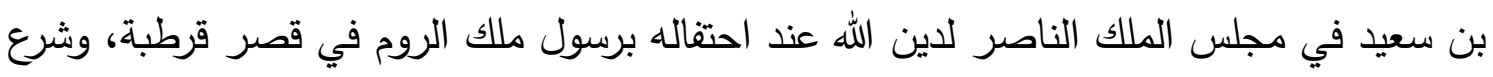

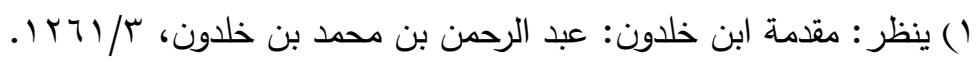

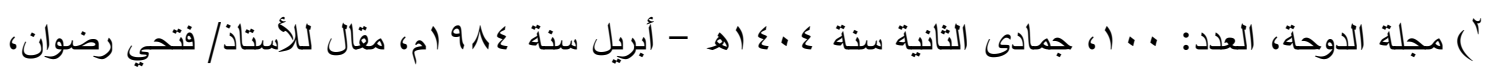

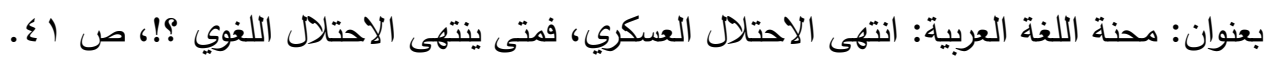


كع التكوين اللغوي للدعاة وأثره في تجديد الخطاب الديني

يخطب من حيث وقف أبو علي البغدادي، وانقطع به القول، فوصل منذر افتتاح أبي علي بكلام عجيب، وأطال النفس في خطبة مرتجلة، فخرج الناس يتحدثون ببديهيته المعجزة، وارتواء لسانه من (اللغة الفصحى" (1) - (2)

فلولا سيف الدولة ما كان المتنبي، ولانْدَثَرَ كما تتدثر مواهب كثيرة في مطاوي الزمن ومجاهيله، أما الاهتمام بالعلوم فإنه مثوى لتصيُّ المواهب المغمورة، وإزكاءٌ للمواهب المشهورة .

\section{r - تدنّي هستوى قَبُول الطلاب في الكليات العربية والشرعية:}

يتوجَّه حَاصِلو أعلى الدرجات من الطلاب في بعض المجتمعات العربية إلى كليات الطب والصيدلة والهندسة واللغات وأمثالها، وما بقي من الطلاب أو لم يُُْرِكِ طموحَه قَفَفَهُ مجموعُ درجاتِه إلىى الكليات العربية أو الشرعية، وترسَّخ في ذهن بعض العامة ما يُسمَّى بكليات القِمّة، وما عداها من كليات فينظرون إليها على أنها مثوى الضعفاء. ودافع هذه التصوُّر هو تعلُّق الآمال بالالتحاق

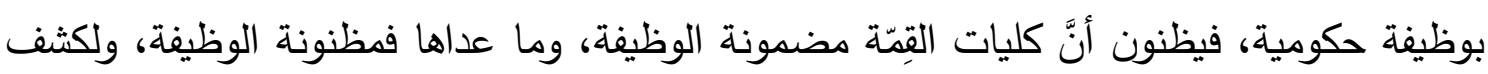
أسباب هذا محله(r)، وما يعنينا هنا هو أن لهذا التصور أثرًا في ضعف العربية. ولو نظرنا إلى الوراء قليلًا لوجدنا أنه "قِقْمَا كان الإقبال على درس العربية وعلومها وعلوم الدين عظيمًا؛ لأن ذلك كان سبيل التفوق في المجتمع، وقد خلف ذلك الإقبال القديم إقبال عصري جديد على الطب والهندسة والتقنيات الحديثة، فأقبل طالبو التفوق على هذه الأبواب من الدرس ولن والتمهيد المهني، وانصرفوا عن فقه اللغة، وملأ الفراغ الذي تركوه أصناف من الطلاب أكثرهم ضعاف الذكاء والتحصيل، وهؤلاء عُهَِ إلى عدد كبير منهم بتعليم العربية، وتخريج أبناء قوميتها

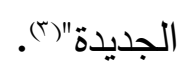

\section{r- التركيز على القواعد وإهـمال الاكات:}

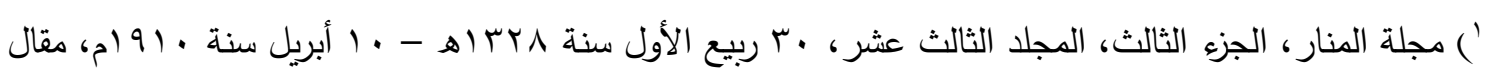

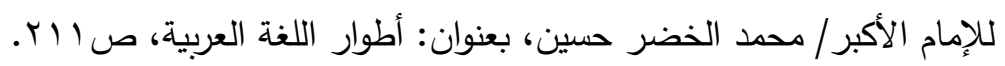

r) ارتباط التعليم بالوظائف نشأ على يد (دنلوب) الذي تولى مقاليد التعليم بمصر إبان الاحتلال البريطاني، وكان

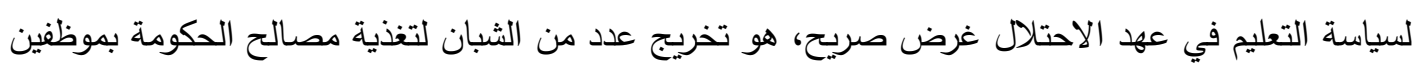

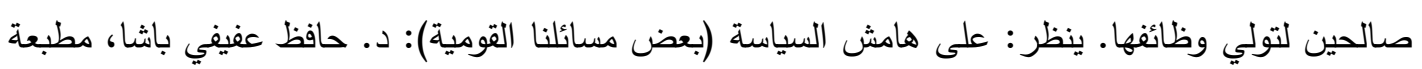

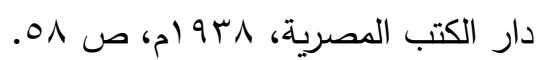

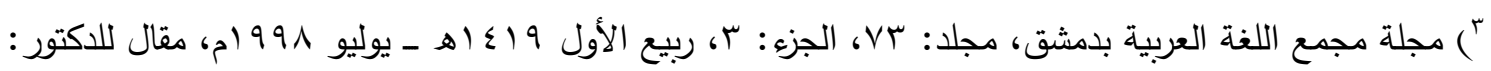

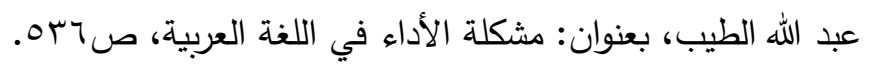




\section{حولية كلية الدعهوة الإسلاهية بالقاهرة}

كes التكوين اللغوي للدعاة وأثره في تجديد الحطاب الديني

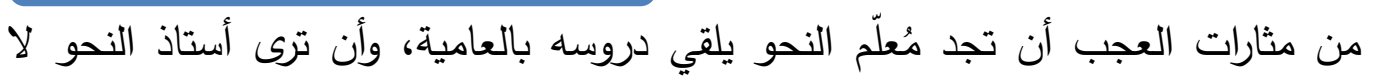

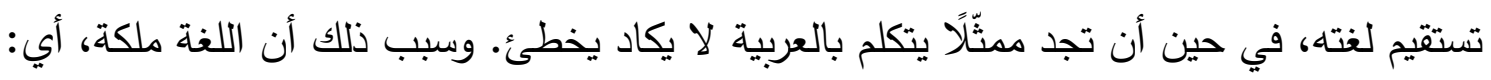

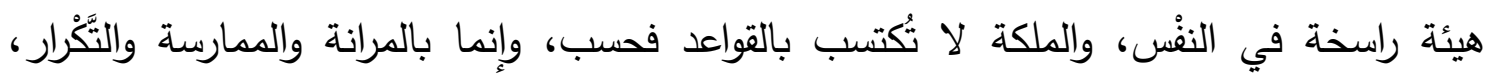
والممثّل قد زاول اللغة وحفظ أدواره فاكتسب الملكة، خلاف مَن حفظ القواعد ولم يزاول اللغة.

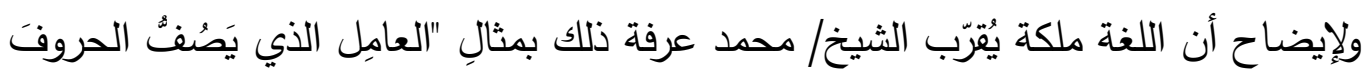

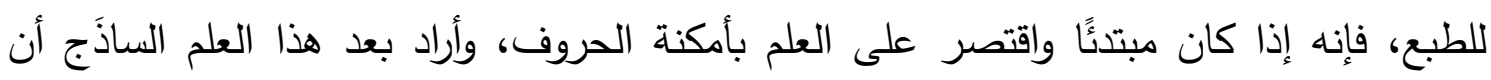

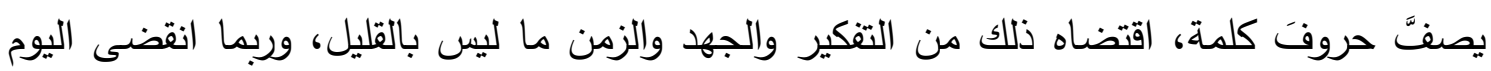

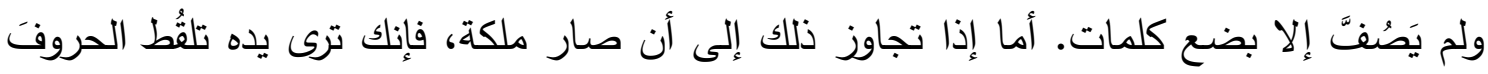

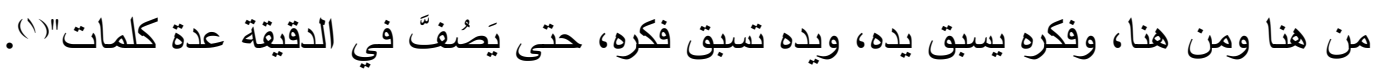
وبذلك ندرك سرَّ نفور بعض الطلاب من العربية، وثِقَّلها عليهم، وبُغْضهم لها وربما لأساتنتها، وهو قيام تعليم العربية على القواعد الجافة، فيحفظ الطالب قواعد لا يرى لهاب لهاب أثرًا في

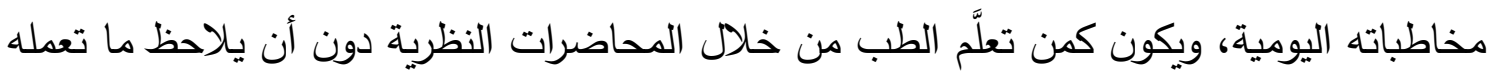

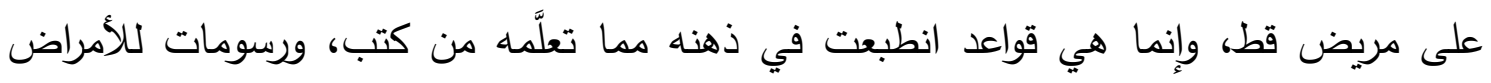
وأعراضها صُوّرت في تلك الكتب.

ولا يَرِدُ على ما سبق هجُرُ القواعد، فغاية ما نريده هو أن تكون عنايتنا بحفظ كلام فصحاء

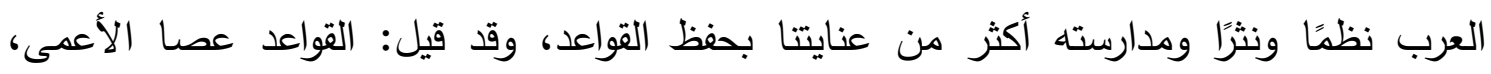

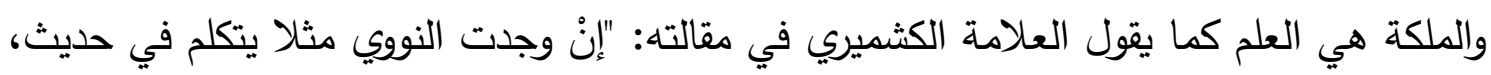

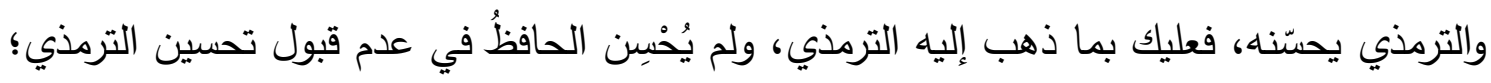

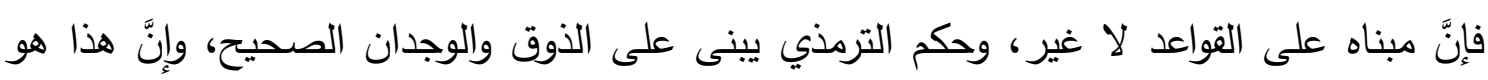

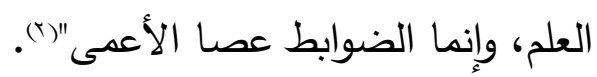

§- إهمال الكتب الصانعة للهلكات:

نشأ الضعف اللغوي في عصرنا الحديث يوم أنْ هُجِرَت الكتب الصانعة للمَعْرِة، وبدأ

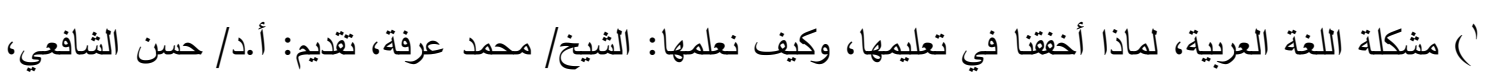

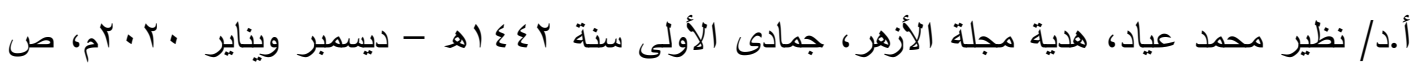

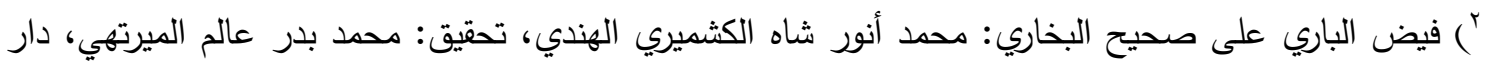

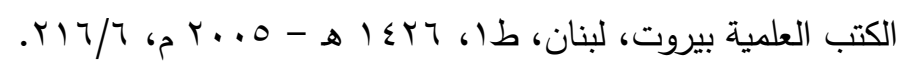




\section{حولية كلية الدعهوة الإسلامية بالقاهرة}

كع التكوين اللغوي للدعاة وأثره في تجديد الخطاب الديني

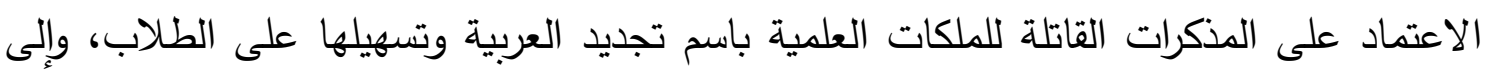

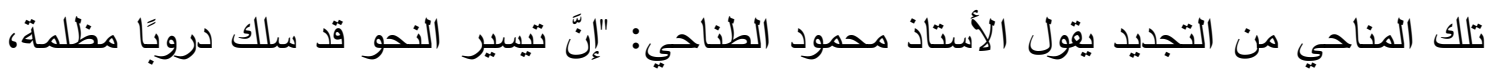

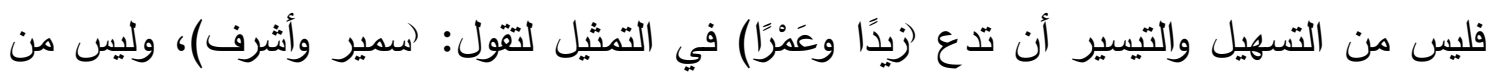
التسهيل أن تترك التمثيل على القاهدة النحوية بالثاهد القرآني والحديثي وأثعار العرب وأمثالها

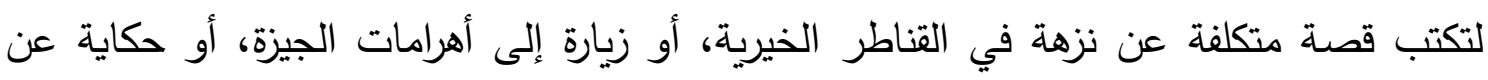
فلاح في الحقل، لتستخرج من كل ذلك شواهد على القواعد النحوية والصرفية" (1).

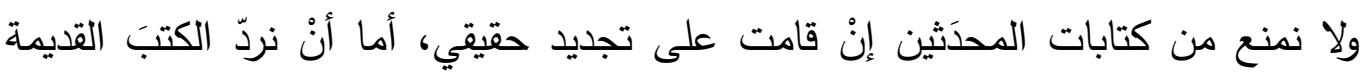
المؤسّة للعلوم، ونستعيض عنها بمذكرات مشوهة، كل ما فيها من جديد هو تغييرٌ في الأمثلة، أو توني

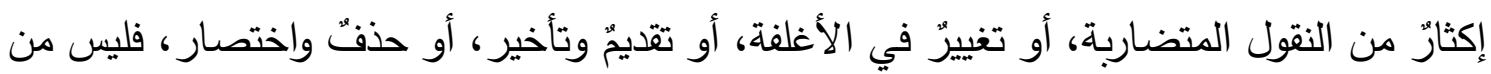

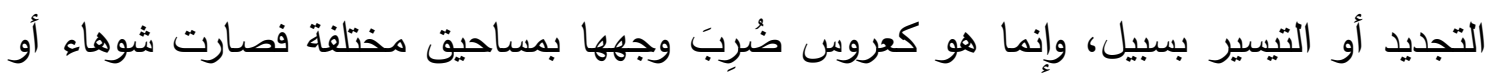

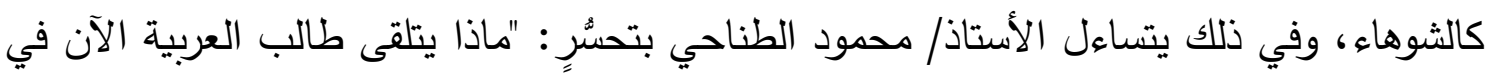

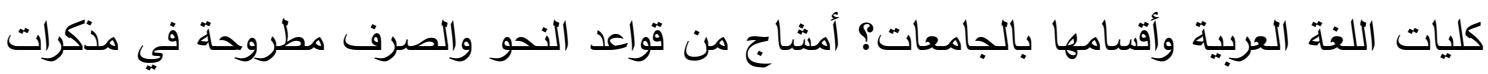

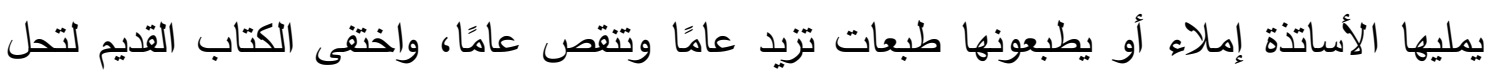

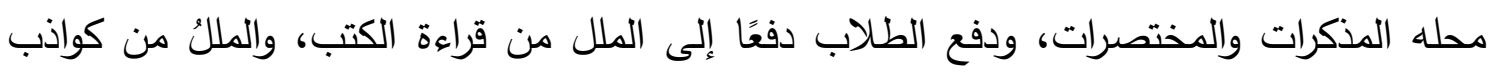
الأخلاق، كما قال عمرو بن العاص رضي الله عنه"(().

ه- ضعف النظام التعليمي:

إنْ قلت: تُعنى العملية التعليمية في الجانب اللغوي بعدة أمور، أهمها: اللغة، والطالب،

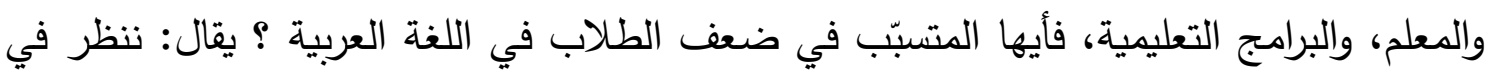

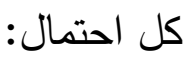

أمَّا اللغة، فبلغ من اهتمام العلماء بها أنْ جعلوها اثني عشر علمًا كما مرَّ، وجعلوا

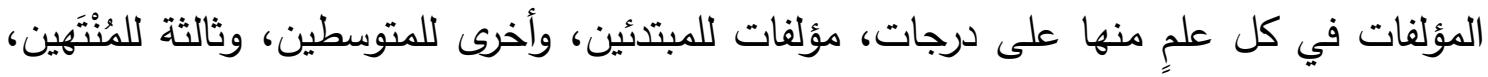

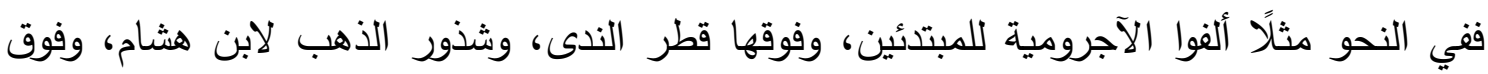

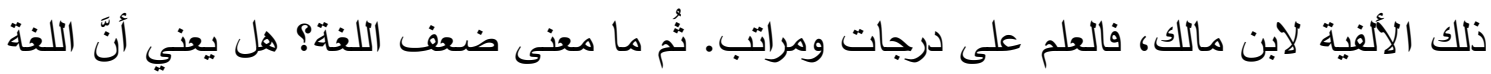

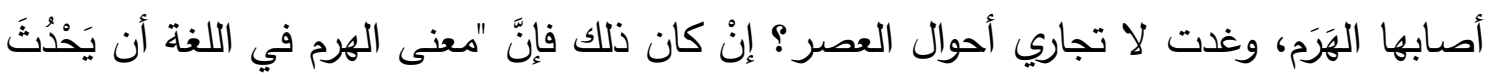

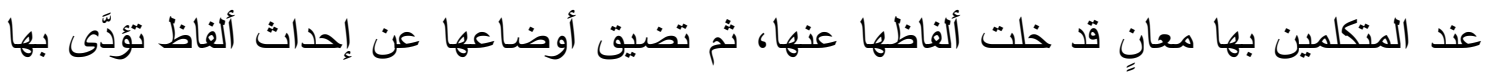

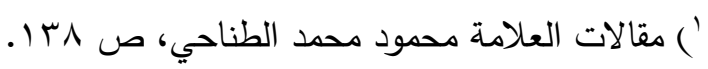
r) المرجع السابق، الصفحة ذاتها. 


\section{حولية كلية الدعهوة الإسلاهية بالقاهرة}

كبع التكوين اللغوي للدعاة وأثره في تجديد الحطاب الديني

تلك المعاني، فيطرأ على اللغة النقص حينًا بعد حين، إلى أن تعجز عن أداء أغراض أهلها، ولا تبقي صالحة للاستعمال، وحينئذٍ فلا يبقى إلا أن يُلْقَى حبلها غلى غاربها، أو يستعان بغيرها على سدّ ما عرض فيها من الخلل بما يغيّر من ديباجتها، وينكّر أسلوب وضعها حتى تتبدل هيئاتها على الزمن، وتصير على الجملة لغةً أخرى"(1).

واللغة العربية ليست بهذه الحال؛ لاشتمالها على الاشتقاق وغيره من طرق الوضع، مما يجعلها قادرة على تحمّل المعاني المستحدَثة، وإذا وَسِعَتْ العربيةُ كتابَ اللهِه أَتَعْجِزُ عن سَعَةِ غيره؟! وفي ذلك يقول حافظ إبراهيم على لسان اللغة العربية(ج):

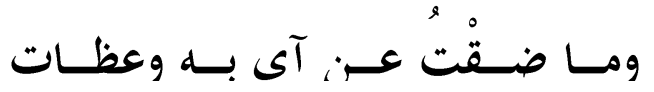
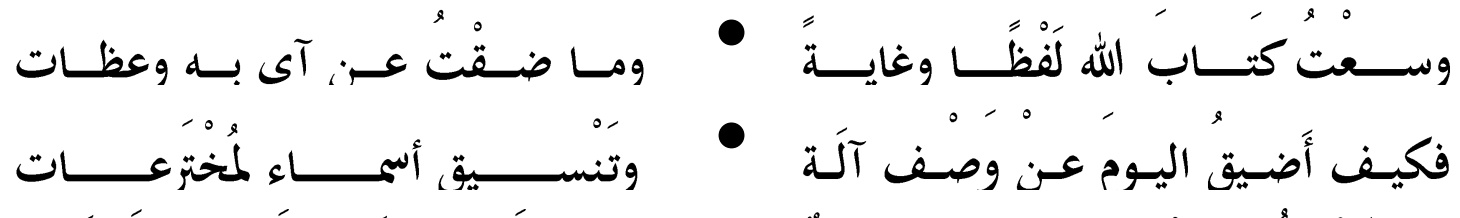
فهـلـل ســأَلوا الغــوَّاص عــن صــدفاتي

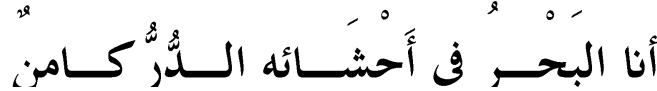

وأمَّا الاحتمال الثاني، وهو الطالب، فإنه ثمرة للتعليم، فالطالب الجيد ثمرة للتعليم الجيد، والطالب الضعيف ثمرة للتعليم الضعيف، وشاهذُ الحس يحكم بضعف غالب الطلاب في العربية، وفي هذا دلالة على أنَّ التعليم الذي قُّْم لهم يشوبه ضعف، وحينئذٍ "فلا يجب أن نقسو كثيرًا على الثباب، فَهُم البذور التي ألقيت، والتعليم الذي أعطي لهج، ومجالات الثقافة التي تلقوها"(ب). وأمَّا الاحتمال الثالث، وهو المعلّم، فأقُرّر ثلاثة أمور : الأول: للمعلّم أثرّز خطيرٌ في قوة الطلاب أو ضعفهم. الثاني: المعلّم الضعيف لا يُنتجج إلا ضعفاء، طبقًا للقاعدة المنطقية القائلة: متي كانت إحدى المقدمتين سالبة كانت النتيجة سالبة. الثالث: المعلّم الجيد يُخرّج طلابًا أقوياء في الغالب؛ لأنه لا يلزم من قوته قوة الطلاب؛ فقد يُلْزَم المعلّم بتدريس كتاب لا يناسب مستوى الطلاب، أو بكتاب لا يصنع فيهم الملكة العلمية، وقد يُغَلٌْ بمنهج لا يتسع لله الوقت المحدد لتدريس المادة، فقوةُ المعلّم وحدها لا تكفي لإنتاج طلاب

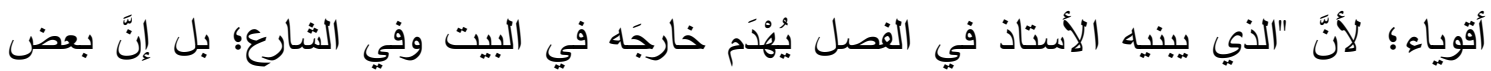
') مجلة البيان، السنة الأولى، الجزء الرابع، أول يونيو سنة 19 ام، ، مقال للأستاذ/ إبراهيم اليازجي، بعنوان: اللغة والعصر ، ص V \& ا ، وما بعدها.

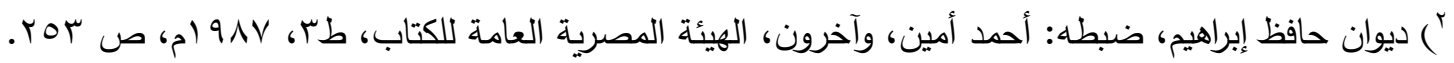

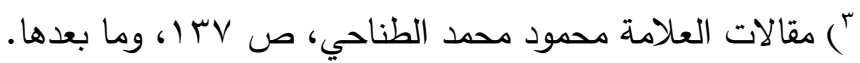


كأبك التكوين اللغوي للدعاة وأثره في تجديد الخطاب الديني

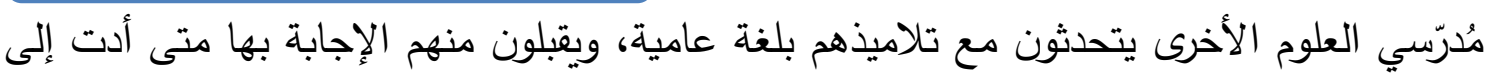
المطلوب، وينشأ من ذلك ما تراه من استهانة التلاميذ بلغتهم الأصلية، ولا يتعودون التجويد، ولا العناية متى كان دون ذلك يُقبل منهم، وما حيلة أساتذة اللغة العربية وحدهم، وهم يبنون وغيرهم (1)" (1) (1)

ومتى فسد احتمال ضعف اللغة والطالب والمعلّم، تعيَّن الاحتمال الأخير، وهو البرنامج التعليمي، فإليه يُسنَدُ الضعف؛ لأنه المحدّد للمُدرّس، والكِتابٍ، وطريقِة تدريس الكتاب، فضعفُ الطالبٍ والأستاذ بعضُ من جزئيات أمر كلي، وهذا الأمر الكلي هو البرنامج التعليمي. لئ. ولما أََْنَذَ أحدُ الكُتَّبَ الضعف في اللغة إلىى الطالب والمعلّم، نَقَدَهُ الأستاذ محمود محمد شاكر مُبينّا أنَّ "أسباب ضعف النشه في العربية ليس يُردُّ إلى المعلم والكتاب، بل مرده إلى المنهج الذي يُقيّد المعلم بقيود كثيرة ترفع عنه التبعة في نتيجة التعليم، ويقيد الكتاب بمثلها، ويُعطى النشء يُّاء ما لا يَصلُح عليه لسان ولا يستقيم به تعليم لغة"(().

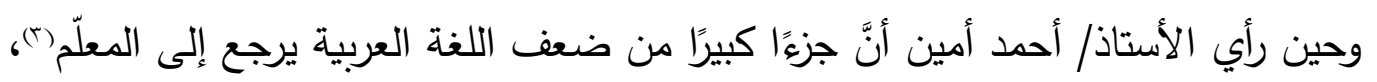
تعقَّبه الأستاذ محمد سعيد العريان، بقوله: "أراني أشارك الأستاذ في قوله: (إن معلّم اللغة العربية في المدارس على اختلاف أنواعها عليه أكبر واجب وأخطر تبعة، وبمقدار قوته أو ضعفه تتكون - إلى حد كبير - عقلية الأمة)، ولكني مع ذلك لا أشاطره الرأي بأن جزءًا كبيرًا من ضعف اللغة يرجع إلى المعلمين، فما المعلمون في مدارسنا، إلا أدوات عاملة بغير إرادة: ليس لهم حرية في العمل، لهاء ولا خيرة في الطريقة، ولا فكرة في التنفيذ؛ وإنما يشرع لهم الثارع في وزارة المعارف، وعليهم الطاعة العمياء، والإرادة الخرساء، قد يكون عيبًا في المعلم أن ينزل عن رأيه بهذا الهوان؛ ولكنه يريد أن

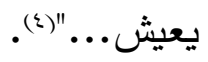
والحاصل أنَّه قد يوجد في المعلّم بعض القصور، وقد يوجد في الكتب الدراسية مثل ذلك، ولكن السبب الأُم في الضعف اللغوي هو منهج السياسة التعليمية:

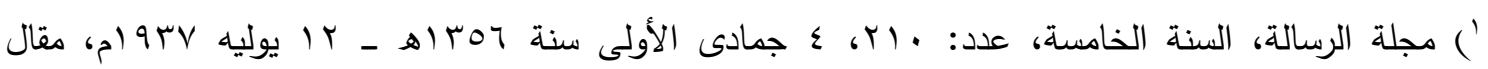

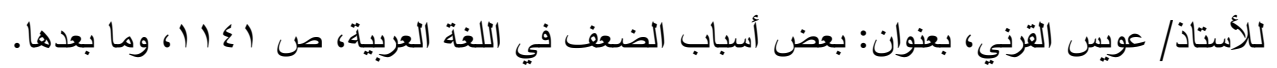

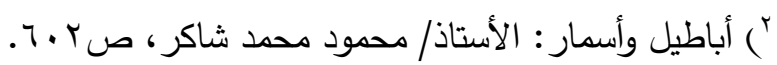

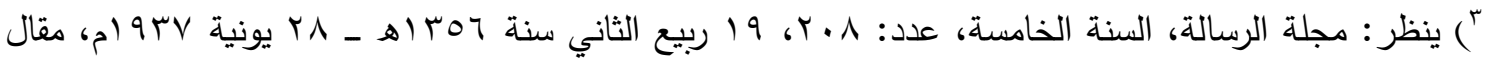

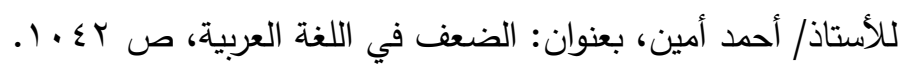

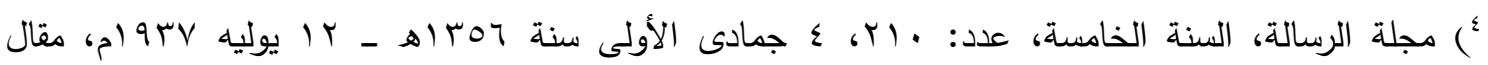

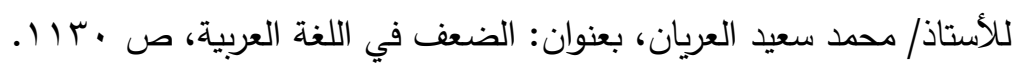




\section{حولية كلية الدعهوة الإسلاهية بالقاهرة}

كئالتكوين اللغوي للدعاة وأثره في تجديد الحطاب الديني

1. فضعفُ المدرّسين، مسؤولٌٌ عنه النظام التعليمي؛ لأنه هو الذي ضمَّهم إلى هيئته التدريسية.

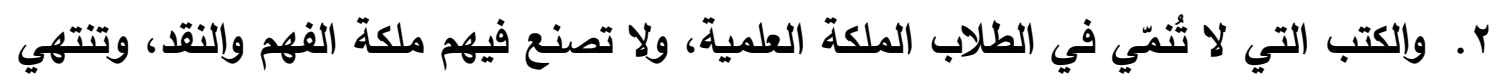
فائدتها إلى شحن عقولهم بمعلومات متنائرة، مسؤولٌ عنها النظام التعليمي.

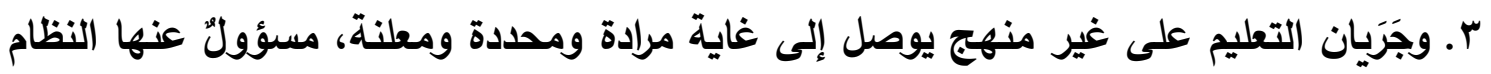

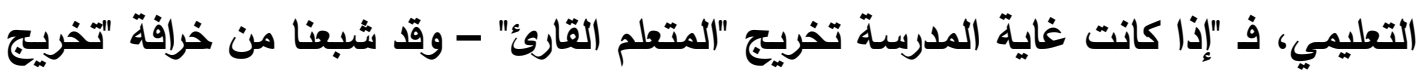

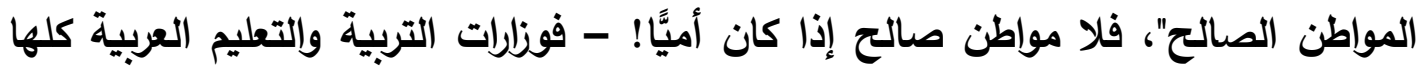

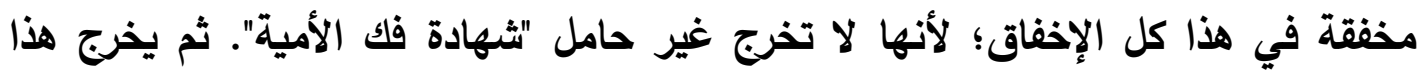

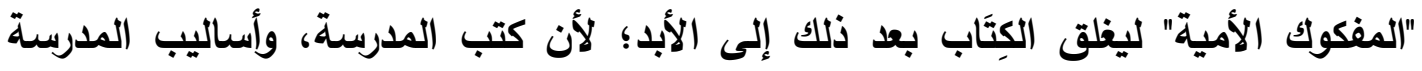

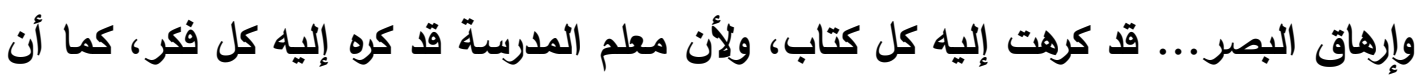

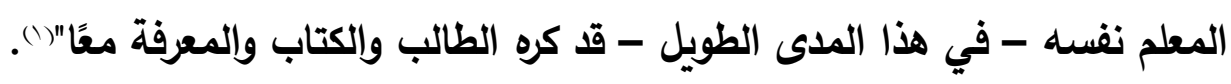
؛ ـ وإهمال الجانب التطبيقي مسؤول عنه النظام التعليمي.

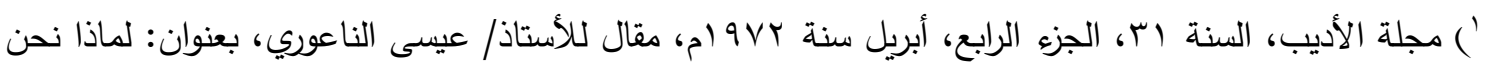
شعب لا يقرأ؟، ص ع. 


\section{المبحث الرابع}

\section{عواهل تنمية الماكة اللغوية للادعاة}

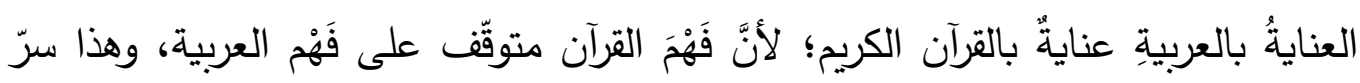

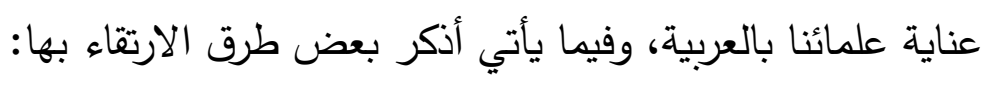

ا - العودة إلى الكتب الصانعة للملكات:

$$
\text { لا بل من معرفة أمرين: }
$$

أولهما: كَتَبَ عُلماؤنا العِلم على ثلاثة مستويات أساسية: المستوى الأول للمبتدئين، والثاني

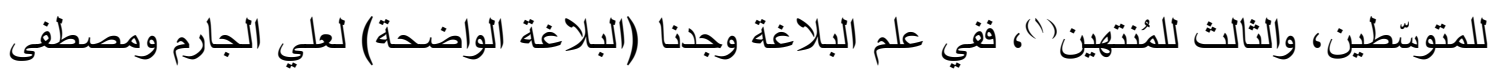

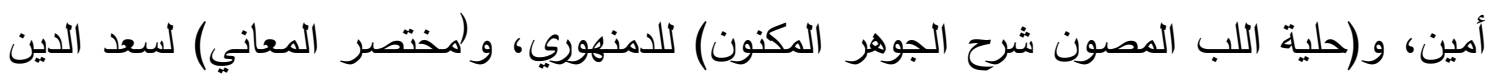

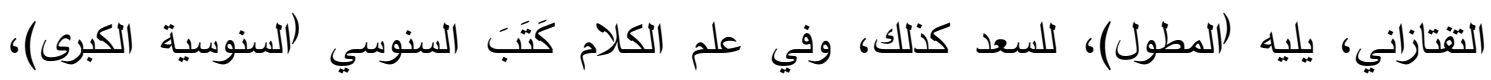

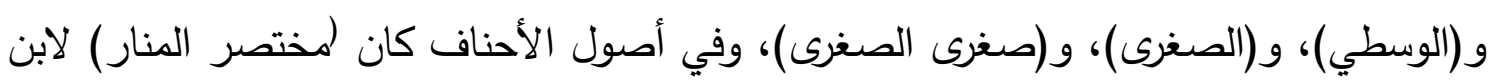

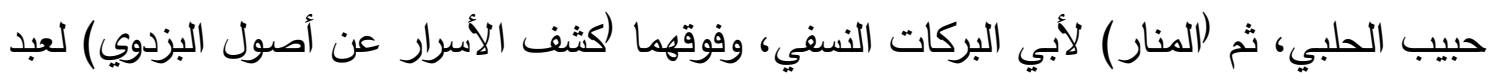

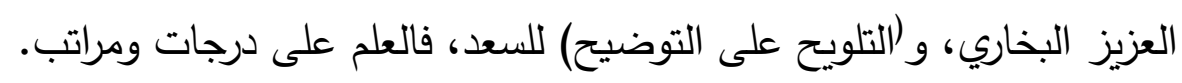

ثانيهما: اعتمد علماؤنا في كل فن كتبًا معينة، وغرضهم من ذلك بناء ملكة علمية راسخة

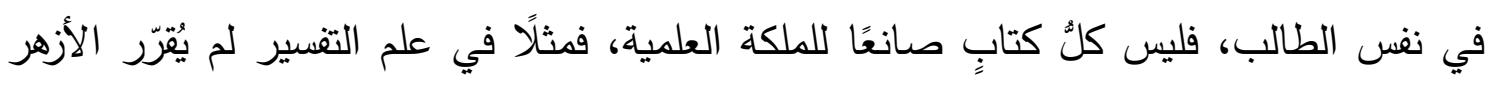

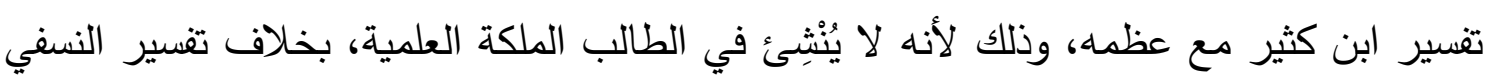

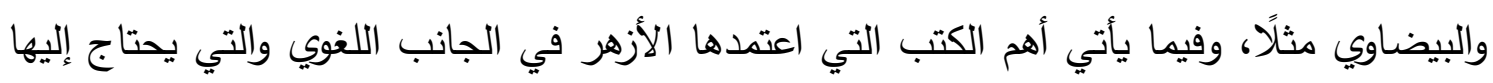

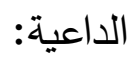

\section{أولاً: علم النهو:}

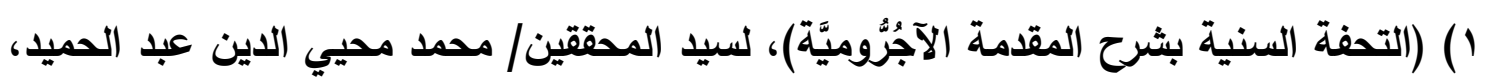

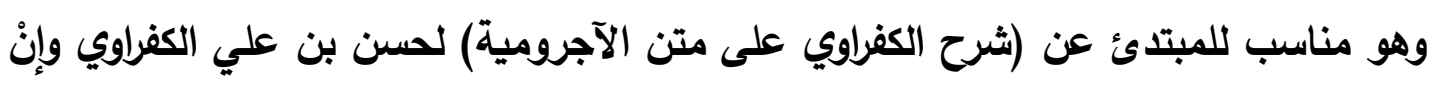

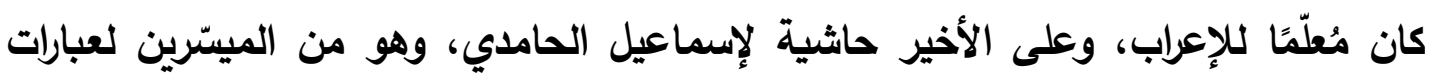

العلماء.

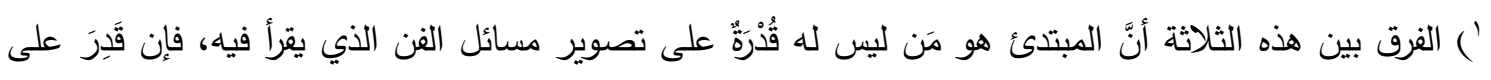

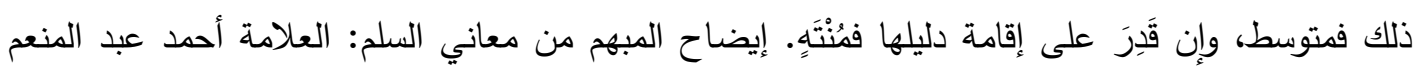

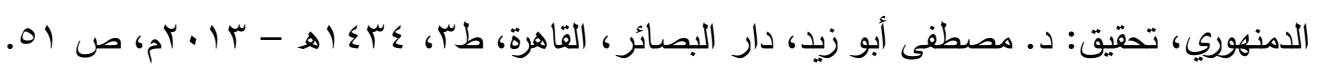




\section{حولية كلية الدعوة الإسلاهية بالقاهرة}

كes التكوين اللغوي للدعاة وأثره في تجديد الحطاب الديني

r) (شرح الأزهرية)، لخالد الأزهري، وعليه: (تنقيح الأزهربة)، لمحمد محيي الدين عبد الحميد، و(شرح الأزهريـة الجديد)، تأليف الأساتذة: عبد اللطيف خليف، وإبراهيم عبد الوهاب، ومحمد محمد عباسي، وعلي علي كرسون، وللثيخ خالد كذلك (المقدمة الأزهرية)، و(التصريح بمضون التوضيح). r) (شرح قطر الندى)، و(شرح شذور الذهب)، كلاهما لابن هثام. ع) (الخلاصة في علم النحو) - ألفية ابن مالك -، ومن أشهر شروحها: (شرح (بن عقيل)، و(أوضح المسائك إلى ألفية ابن مالك) لابن هثام.

•) (الاقتراح في علم أصول النحو) لجلال الدين السيوطي، و(همع الهوامع شرح جمع الجوامع) له كذلك، وجمع الجوامع السابق خلاف جمع الحوامع لتاج الدين السبكي في علم أصول

$$
\begin{aligned}
& \text { ؟) (مغني اللبيب عن كتب الأعاربب) لابن هثام، و(الكتاب) لسيبويـه. } \\
& \text { ثانياً: علم الصرف: }
\end{aligned}
$$

1) (عنوان الظرف في فن الصرف)، لهارون عبد الرازق، و(دروس التصريف) لمحمد محيي الدين عبد الحميد، و(الجامعة الصرفية) لمحمد خليل الخطيب، و(المغني في تصريف الأفعال)، و(اللباب في تصريف الأفعال)، كلاهما لمحمد عبد الخالق عُضَيمة. r) (شرح تصريف العِّي) للشريف الجرجاني، وشرحه سعد الاين التفتازاني، و(شرح شافية ابن الحاجب) لرضي الاين محمد بن الحسن، المعروف بالرضي.

ثالثا: علم البلاغة:

(1) (دروس البلاغة)، لحفني ناصف، ومحمد دياب، وسلطان محمد، ومصطفى طموم، أو (علوم البلاغة)، أحمد مصطفى المراغي، أو (الجوهر المكنون) لعبد الرحمن الأخضري، ومن

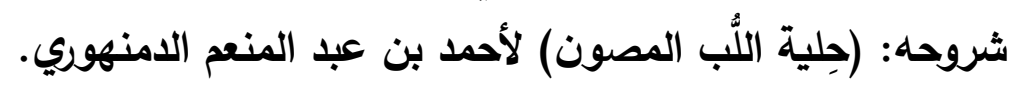
ץ) (أسرار البلاغة)، و(دلائل الإعجاز)، كلاهما لأبي بكر عبد القاهر الجرجاني، طُبِّا بتحقيق:محمد رشيا رضا، وبتحقيق: محمود محمد شاكر، وبتحقيق: محمد عبد المنعم خفاجى. وقيل عن هذين الكتابين: (بَحْرَان تنشعب منهما العيون) (1). r) (مفتاح العلوم) لأبي يعقوب يوسف السكاكي، في النحو والصرف والبلاغة، وقد أحدث السكاكي منعطفًا في علم البلاغة؛ حيث اعتنى بتهذيب العلم وترتيب مسائله، فاهتم

$$
\text { ') أبجد العلوم: صديق بن حسن القنوجي، r/ آب ا. }
$$




\section{حولية كلية الدعهوة الإسلامية بالقاهرة}

كبع التكوين اللغوي للدعاة وأثره في تجديد الحطاب الديني

المتأخرون بجزء البلاغة من كتاب المفتاح، وأفردوه بالتأليف، ومن أشهر ملخصاته:

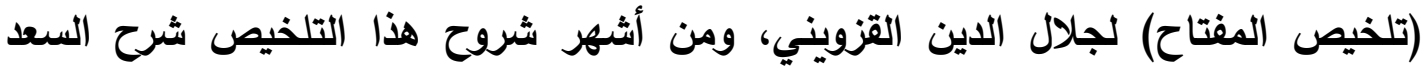
التفتازاني المعروف بـ (المطول شرح تلخيص مفتاح العلوم)، ثم اختصر السعد هذا المطول

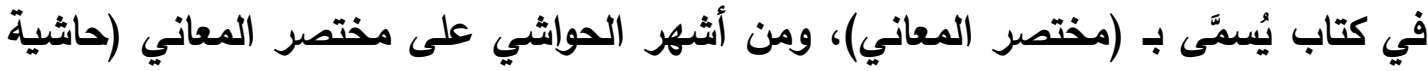

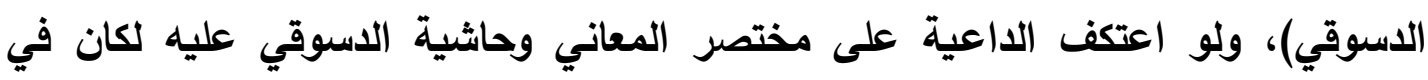
العربية والأصول عظيمًا.

؛) (الرسالة السمرقندية في الاستعارات)، لأبي القاسم بن أبي بكر الليثي السمرقندي، وعليها

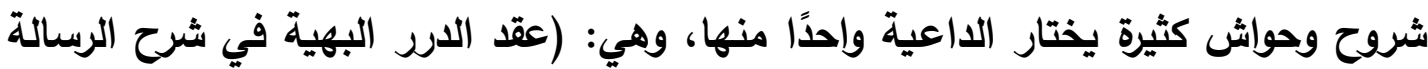

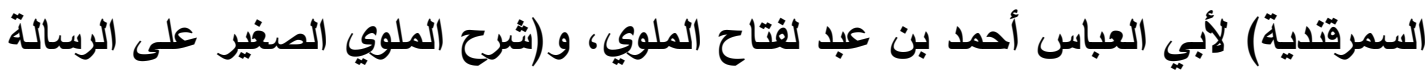

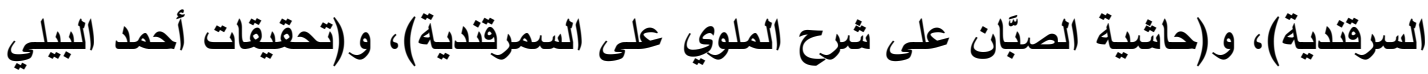

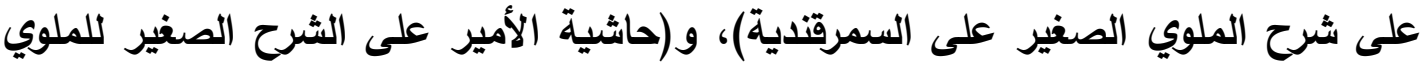

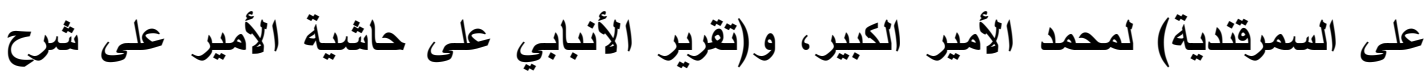

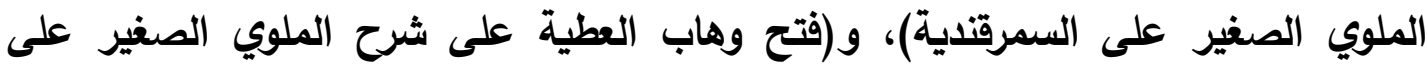

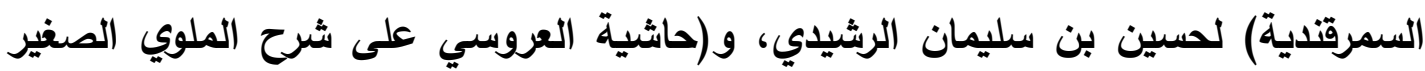

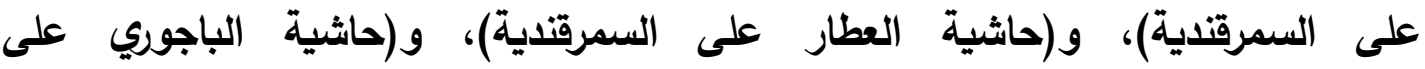
السمرقندية)، و(لقط الجواهر السنية على الرسالة السمرقندية) لمحمد الدمنهوري.

\section{رابعا: علم هتن اللغة:}

1) (مختار الصحاح) لمحمد بين أبي بكر اللرازي، اختصره من كتاب (تاج اللغة وصحاح العربية) للجوهري، ولا غنى للاعية عن هذا المختصَر. r (معجم مقاييس) (اللغة لأبي حسين أحمد بن فارس. r) (لسان العرب) لابن منظور، جمعه من خمسة مصادر أساسية، وهي: (تهذيب اللغة) لأبي

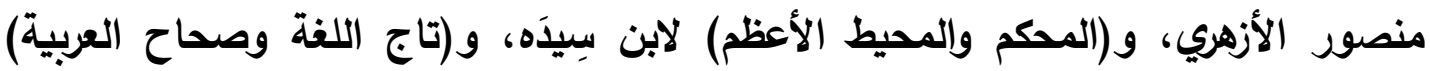
للجوهري، و(حواثي (بن بري على صحاح الجوهري)، و(النهاية في غريب الحديث والأثر) لعز الاين ابن الأثير. ؛) (القاموس المحيط) لمحمد بن يعقوب الفيروزآبادي، و(تاج العروس من جواهر القاموس)، لمحمد مرتضى الزبيلي. خامسًا: علم الإملاء (الخط): 


\section{حولية كلية الدعهوة الإسلاهية بالقاهرة}

كع النكوين اللغوي للدعاة وأثره في تجديد الخطاب الديني

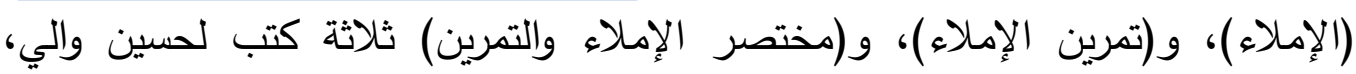

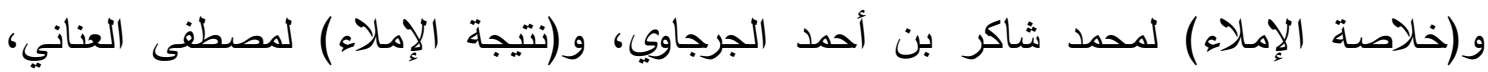

$$
\text { و(قواعد الإملاء وعلامات الترقيم) لعبد السلام هارون. }
$$

سادسًا: عِلم الثعر، والعروض، وإلقافية، والإنشاء:

1) (القسطاس في علم العروض) لمحمود بن عمر الزخشري، و(المرشد الوافي في العروض والأفاء :

والقوافي) للاكتور محمد حسن عثمان.

r) المعلقات العشر وشروحها كثرح الزوزني، ودواوين فحول الشعراء كالمتنبي والمعري والبحتري وأبي نواس وأبي فراس.

r) (البيان وإلتبيين) لأبي عثمان عمرو بن بحر الجاحظ، و(رسائل الجاحظ) أخرجها عبد السلام

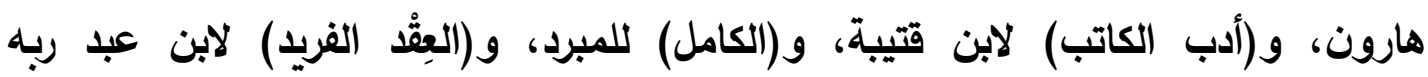

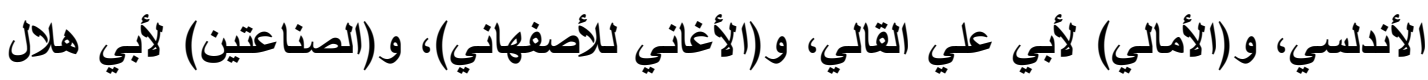

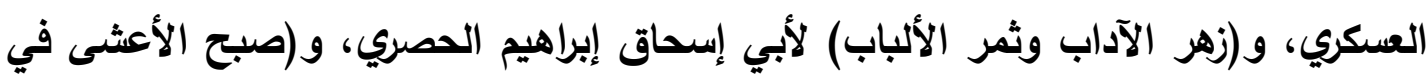

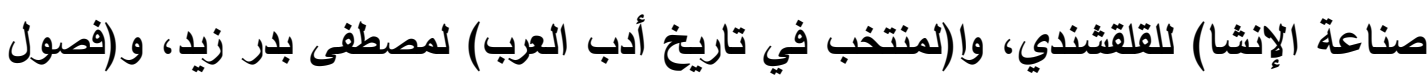

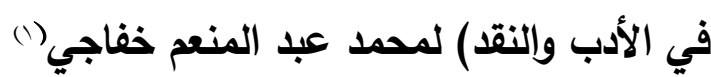

فإنْ قلتَ: اقتنيتُ شرح قطر الندى، وتعسَّر عليّ، أو قرأت للأعشى ولامرئ القيس،

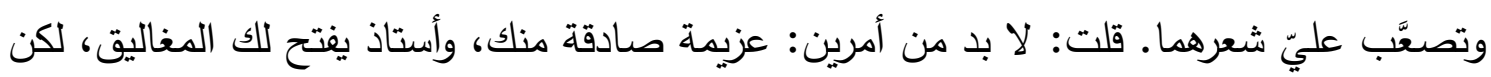

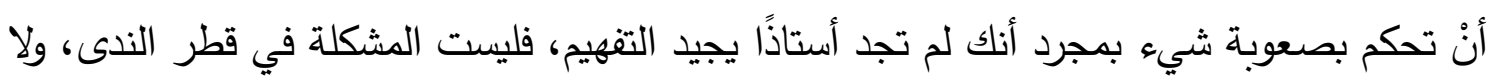

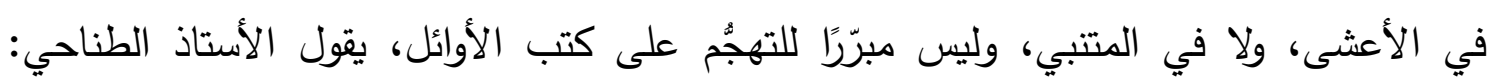

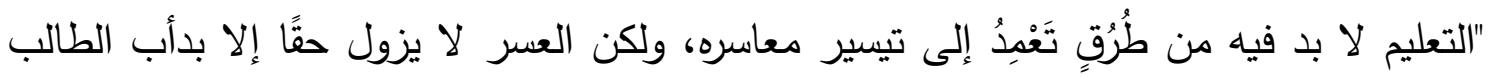

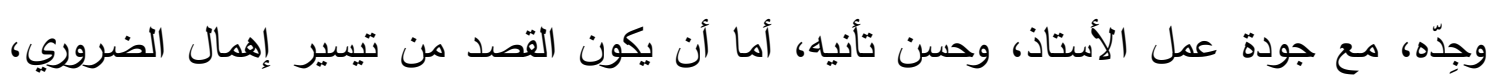

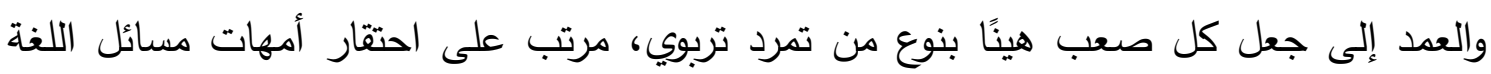

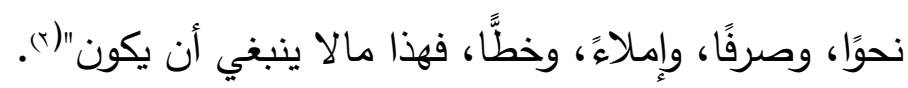

\section{r- تدريس العربية برؤية تكاهلية تطبيقية:}

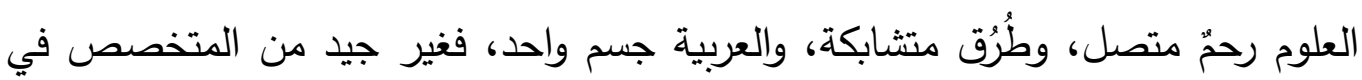

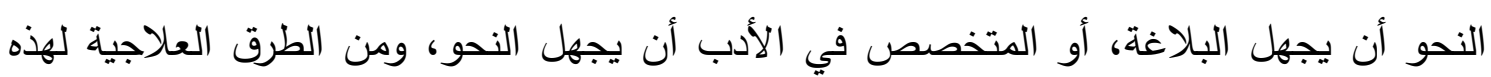

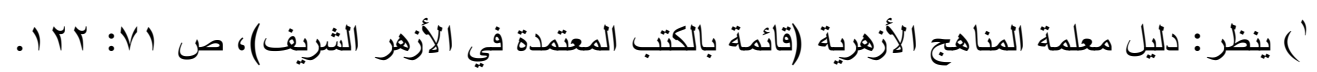

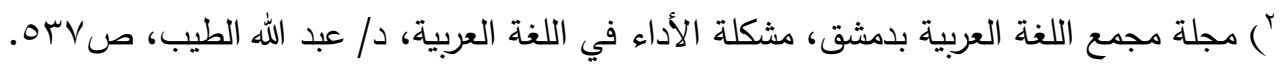


كع التكوين اللغوي للدعاة وأثره في تجديد الخطاب الديني

الحالة " أنْ نخصص في كل سنة ساعتين أسبوعيَّا للتدريب على علوم اللغة العربية مجتمعة، وتدريس أساليب العرب من خلال نصوص، لا ندرسها فنيًّا أو جماليّا على نحو ما نفعل في دروس التحليل الأدبي، ولكننا ندرسها من خلال علوم العربية كلها، فندرس مع طلابنا حروفها، وأصواتها، ومخارجها، وتآلفها، وتتافرها، وندرس ألفاظها باشتقاقها، وأبنيتها، وإعرابها، وتطور معانيها، ومواضعها التي جاءت فيها، ومقتضيات وضعها ذلك الوضع الذي جاءت عليه من التركيب اللغوي، وندرس أساليبها المختلفة، ودواعي تنوعها، إنه الدرس الذي يقود الطالب إلى حسن استثمار ما تعلمه نظريًا في علوم العربية كلها ليستقر في نفسه أنها علوم متكاملة تسعى إلى هدف واحد، ودي،

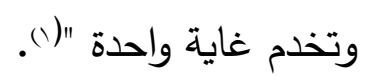

فنقرأ نصوصًا نستخرج منها النحو، والصرف، والبيان، والمعاني، والبديع، والعروض، ومتن اللغة، فيتعود الطالب على ربط العلوم بعضها ببعض، ويتقوَى فيما يظهر فيه ضعفه. وهنا أمر دقيق أشار الأستاذ محمد سعيد العريان، وهو أننا نتعلم العربية بطريقة معكوسة، فنعطي للطالب قواعد العربية، وإذا قرأ لم يقدر على تطبيق ما حفظه من قواعد، والطريقة المثلى التي يراها الأستاذ محمد سعيد العريان، هو أن نبدأ بتقديم نماذج من منثور العرب وأشعارهم؛ لأن ممارسة كلام العرب، والتمعُن في أشعارهم ودواوينهم يصنع الملكة اللغوية، وتكون القواعد مرحلة لاحِقة، يقول: "إن الآفة والعلة والداء ليست في قواعد البلاغة، ومصطلحات النحو، وفصول الأدب... ولكن العلة والآفة والداء أننا نُعلّم التلميذ قواعد اللغة قبل أن يعرف شيئًا من اللغة، أو يقرأ منها قدرًا صالحًا ليعينه على الفهم والمحاكاة، وأننا نُدرّس له البلاغة قبل أن نُقدّم له النماذج الكثيرة من الكلام البليغ التي تتبه فيه ملكة النقد قبل أن نعطيه قواعد النقد ومقاييس البيان الرفيع، وأننا نجرّعه مصطلحات الأدب وفنونه قبل أن يتذوق الأدب نفسه، من هنا العلة فلنلتمس لها الدواء قبل أن نفكر في حلاوته أو مرارته "(().

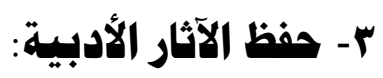

أشار ابن خَلدون إلى أنَّ حصول الملكة اللغوية يكون بكثرة حفظ كلام العرب، وجودة هذه الملكة يكون بجودة المحفوظ؛ لأنه "بارتقاء المحفوظ في طبقته من الكلام ترتقي الملكة الحاصلة؛

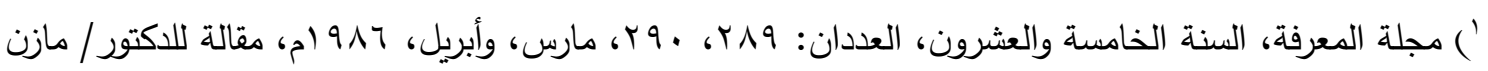

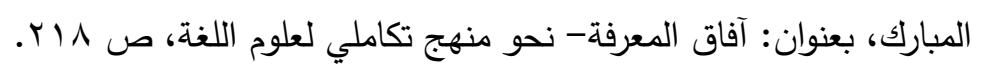

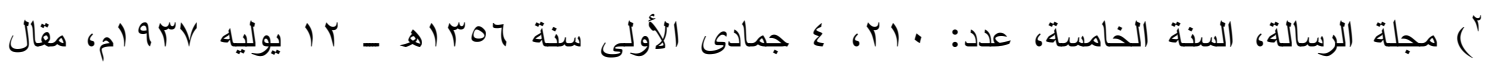

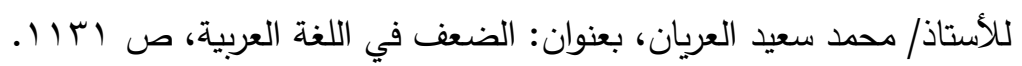




\section{حولية كلية الدعهوة الإسلاهية بالقاهرة}

كهي التكوين اللغوي للدعاة وأثره في تجديد الخطاب الديني

لأن الطبع إنما ينسج على منوالها، وتتمو قوة الملكة بتغذيتها"(()

ومن هذا الطريق، نصَّ الرافعي على أنه لا فصاحة، ولا لغة، إلا بالحرص على القرآن،

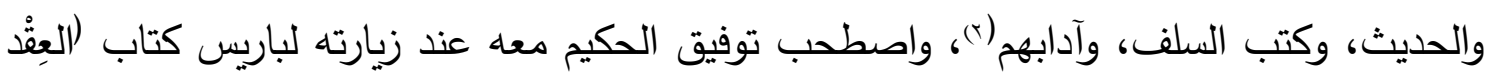

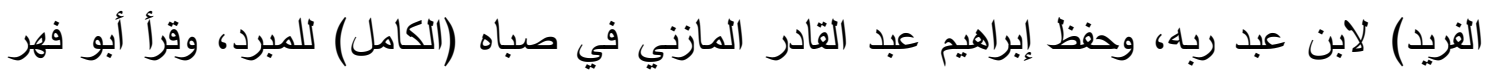

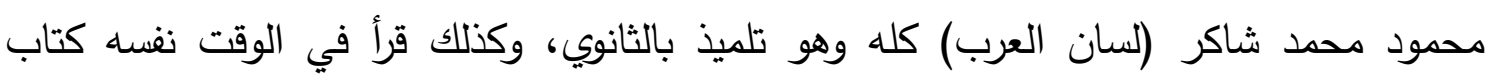

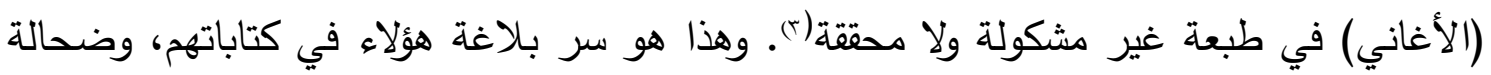
وسقم كتابة أناسٍ أعرضوا عنها، ورموها بالجمود والقدم.

وحين نادى بعض الكُتَّب بهجر الآثار العربية القديمة، والتوجُه شطر شكسبير وأثباهه، واجههم الأستاذ شاكر بقوله: "ليس يكون لنا مثل شكسبير وأصحابه إلا باستيعاب قديم كتابنا

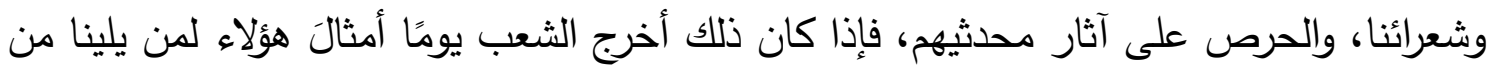

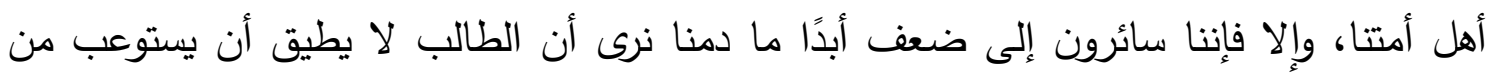
شعر البحتري إلا قصيدة واحدة، ومن المتنبي مثلها، ثم يكون ذلك آخر عهده وأوله بدراسة الآثار

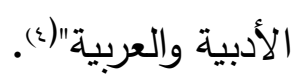

ودلالة كلامه أنَّ شكسبير وأمثاله من الأعلام الأدبية الأجنبية، لم ينشأوا من فراغ لغوي

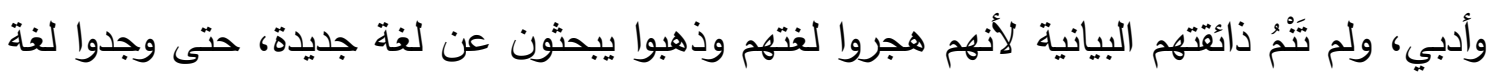

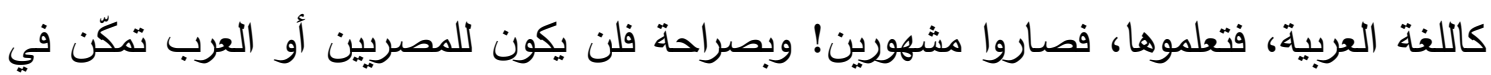

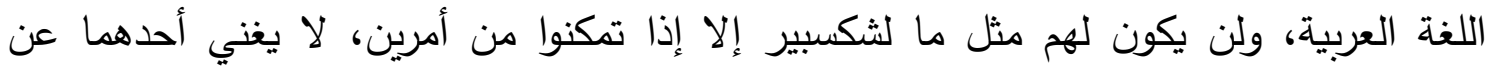

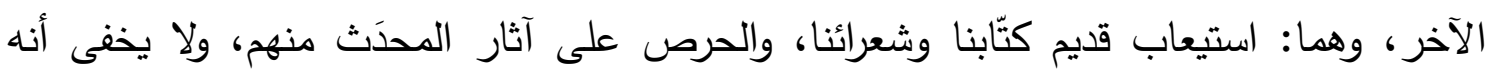

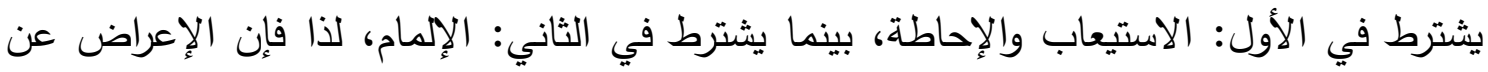

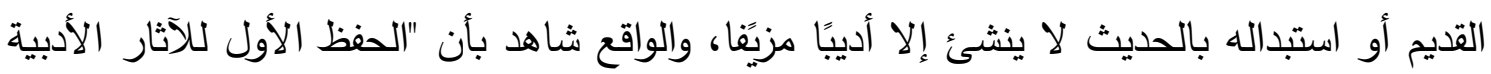

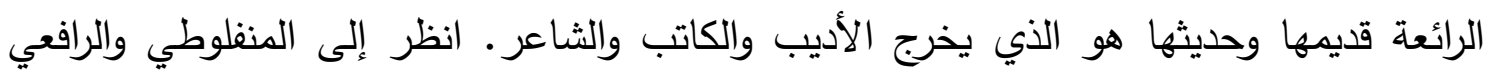

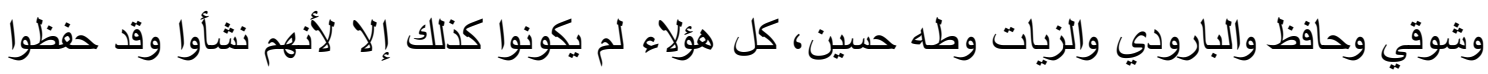

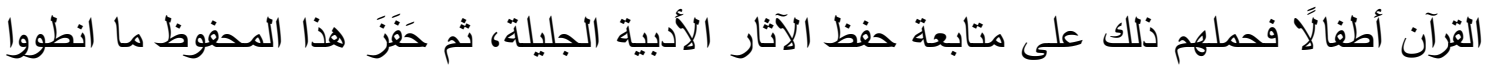

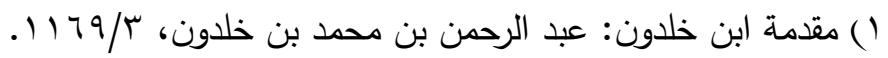

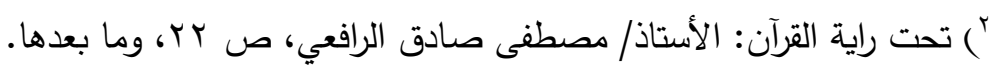

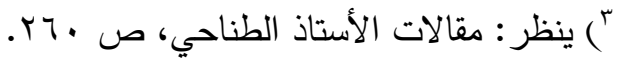

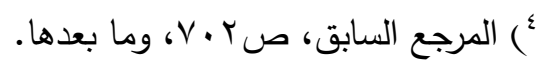




\section{حولية كلية الدعوة الإسلاهية بالقاهرة}

كبك التكوين اللغوي للدعاة وأثره في تجديد الخطاب الديني

عليه من الطبيعة الأدبية التي استقرت في أنفسه وأعصابهم، فلما استحكموا استحكمت لهخ طريقتهم في الأدب والثعر والإنشاء، ولولا ذلك لما استطاعوا أن يكونوا اليوم إلا كما نرى مِنْ سائرهم، مَنْ تخرجهم دور التعليم بالآلاف في كل عام ينقضي من أعوام الدراسة"((). ويؤيد ذلك قول الثيخ محمد عرفة: "سَلوا كلَّ كاتبٍ يحوك الوشْيَ وينفُث السحر، وكلَّ شاعرٍ يقول الشعر وينظِم الدَُّّ، في مصر وفي بلاد الثرق: بماذا نِلْتم هذه المنزلة ووصلتم إلى هذه الدرجة من البيان؟ يجيبوك بأنهح لم ينالوا هذه المنزلة إلا بالقراءة الكثيرة، والحفظ الكثير، ومزاولة الكتابة والحديث" (؟). مدهن ولو أن العرب تعلموا وحفِظوا كلَّ الآداب الإنجليزية والألمانية أو غيرهما من الآداب الأجنبية، فإنه سيكون لهم كُتّاب ينطبق عليهم (النسخة المصرية في الأدب الإنجليزي أو الألماني أو الفرنسي)، نَسْنُ وتقليدٌ ومحاكاةٌ.

وعلى المقابل، فالثكوى من القديم والذَمْر منه، وتقليله واختصاره واختزاله ليؤول إلى طلاسم ورموز تثير إلى شيء من المعرفة بزعم التخفيف والتطوير والتجديد ومحاكاة العصر ، فهذا

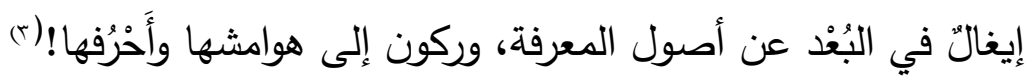
ع- إعلاء شأن المأسسات المسؤولة عن هماية الاغة العربية: تعزيز المؤسسات المنوطة بحماية اللغة العربية، والعناية بها، وإمدادها بمقومات وأسباب نهوضها، من الطرق العملية المؤثّة في الحفاظ على اللغة العربية، ومن أهم المؤسسات المسؤولة عن حماية اللغة العربية ونشرها:

أ- الأزهر:

يحمل الأزهر أمانة إلهية، منذ أنشأه المعز لدين الله الفاطمي حتى عصرنا هذا، هي الحفاظ على الشريعة الإسلامية، وعلى اللغة العربية، عن طريق التفرُّغ لهما علمًا وعملً، فقد نصت المادة الأولى من قانون الأزهر على أنَّ "الجامع الأزهر هو المعهد الديني العلمي الإسلامي

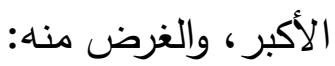

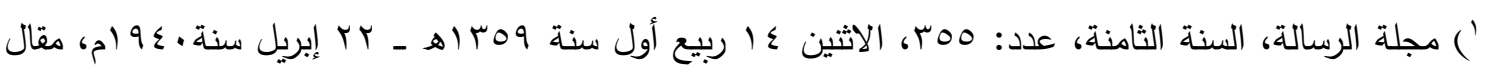

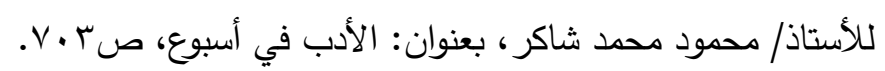

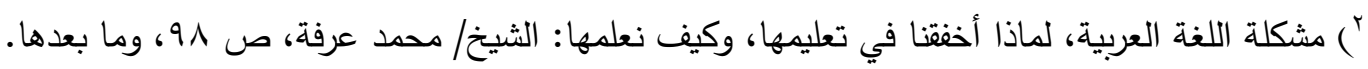

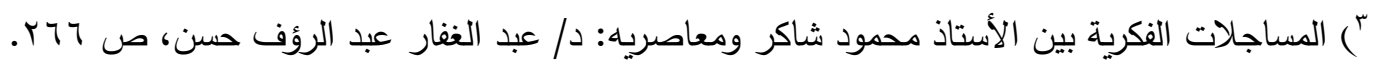




\section{حولية كلية الدعوة الإسلاهية بالقاهرة}

كبع التكوين اللغوي للدعاة وأثره في تجديد الحطاب الديني

1 ـ القيام على حفظ الثريعة الغراء أصولها وفروعها، واللغة العربية، وعلى نشرهما. r. تخريج علماء يُوكل إليهم تعليم علوم الدين واللغة في مختلف المعاهد والمدارس" (1). فالمهمة الأوُلى للأزهر هي الحفاظ على الثريعة الغرَّاء، واللغة العربية، وهذا يتطلب العناية

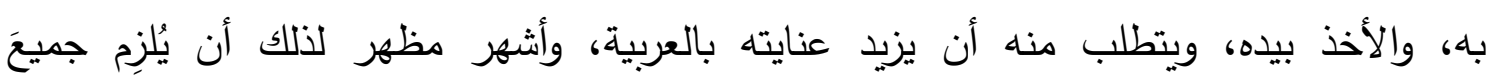

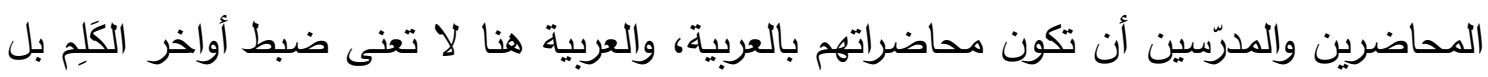
تشمل كذلك التذوق البياني، والحس الأدبي.

\section{ب - هجامع اللغة العربية:}

يُناط بمجامع اللغة العربية العناية بسلامة اللغة العربية، فمن أغراض مجمع اللغة العربية

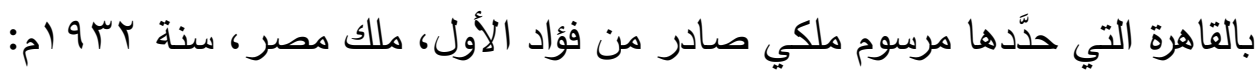

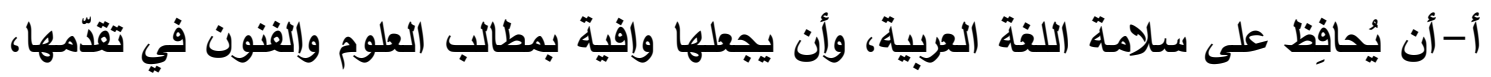

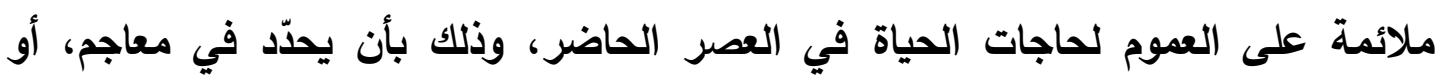
تفاسير خاصة، أو بغير ذلك من الطرق، ما ينبغي استعماله أو تجنبه من الألفاظ والتراكيب.

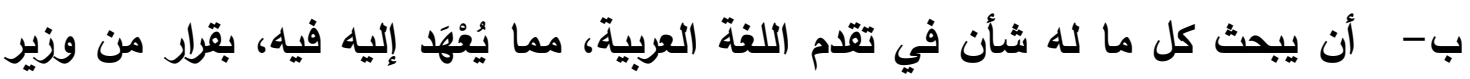

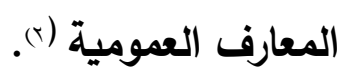

وانطلاقًا من هذه المسؤولية، أصدر المجمع توصيات في سنوات متعاقبة، أهمها:

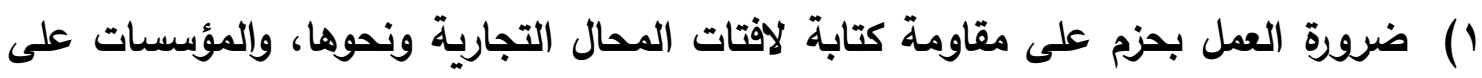

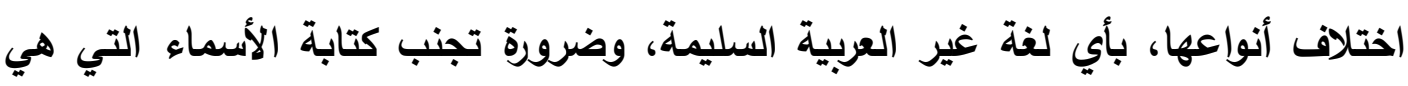

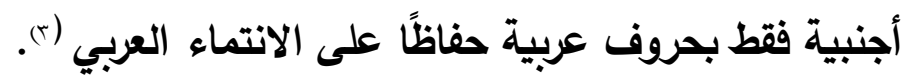

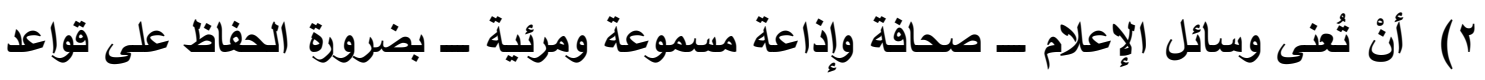

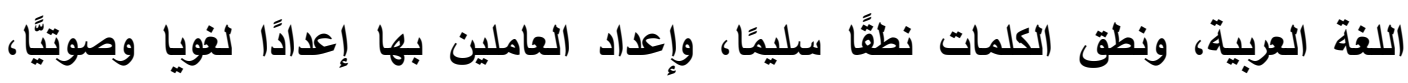

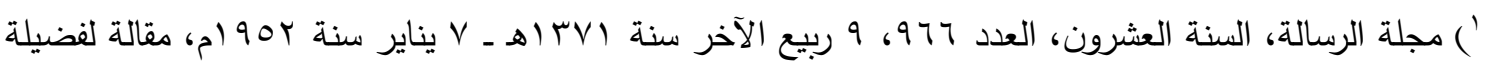

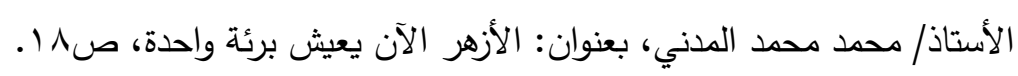

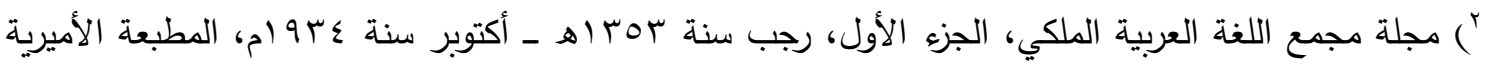

$$
\text { ببولاق، هبو (م، ص 7 7، وما بعدها. }
$$

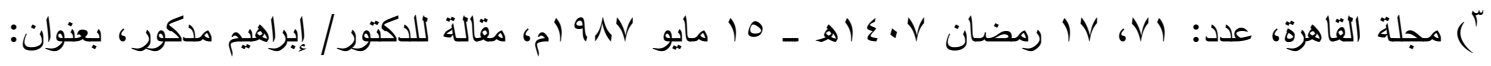
توصيات مؤتمر مجمع اللغة العربية بالقاهرة في الدورة الثالثة والخمسين 9AV ام. 


\section{حولية كلية الدعوة الإسلاهية بالقاهرة}

كeك التكوين اللغوي للدعاة وأثره في تجديد الحطاب الديني

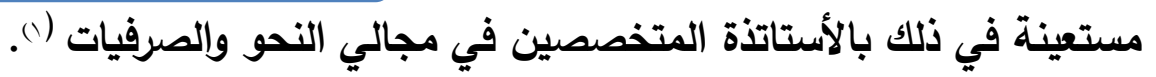

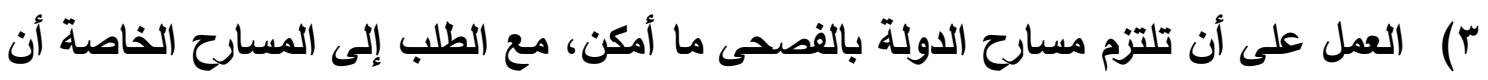
تُعنى بلغة تمثيلياتها، وترتقي بها تدريجيًّا.

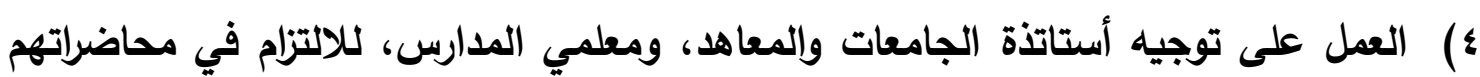
ودروسهم، وفي مناقشاتهم بالفصحى (غ).

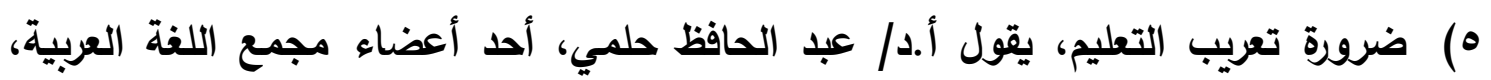

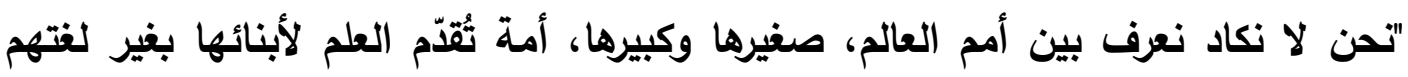

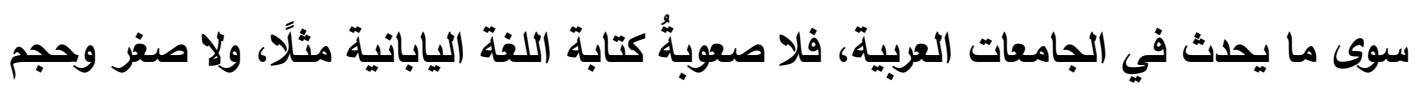

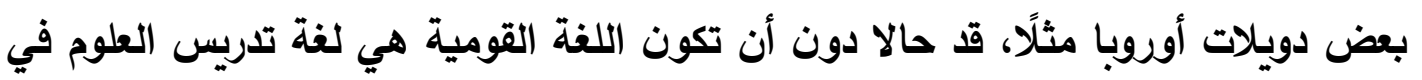

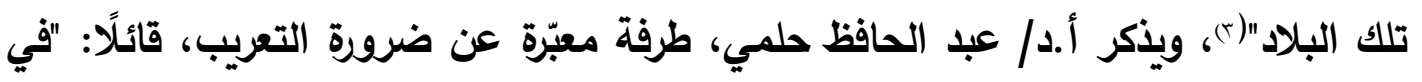

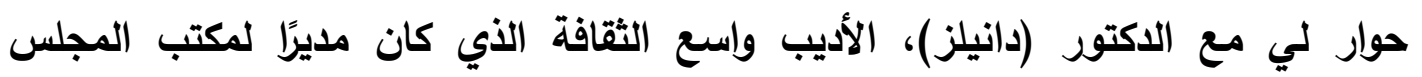

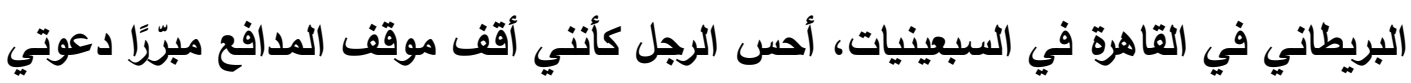

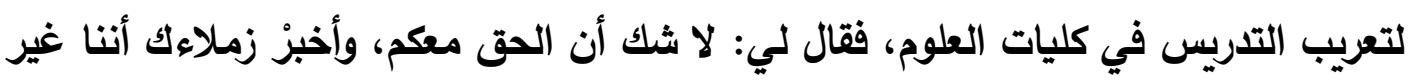

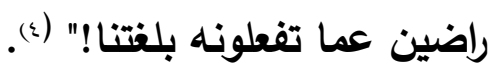
أصدرت ـ ولا تزال ـ المجامع توصياتها، ويبقى أنْ يأخذ المعنيُّن هذه التوصيات بيد الجِدّ، ويعملون على تطبيقها، فما يعوزنا هو التطبيق، لا التنظير . وعلى الجملة، فالحقيقة المفزعة هي أنَّ اللغة في خطر داهم، وأول طُرُق الخلاص من ذلك، أنْ

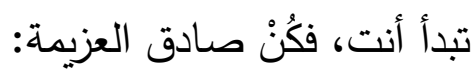
اـ اختر كتابًا في كل فن من فنون العربية، وأن يكون غرضُك من التعلُّم حصولَ ملكة العلم

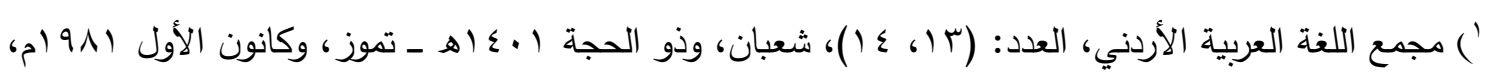

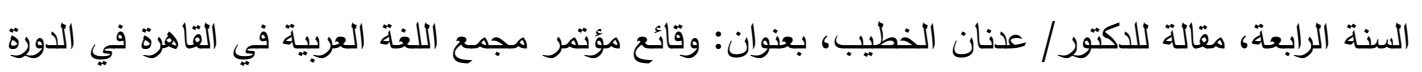

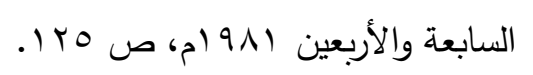

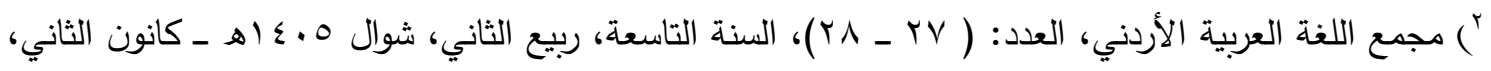
حزيران، و19 ام، مقالة للدكتور/ عدنان الخطيب، بعنوان: وقائع مؤتمر مجمع اللغة العربية بالقاهرة في

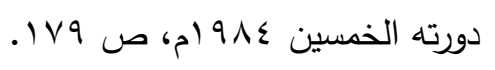

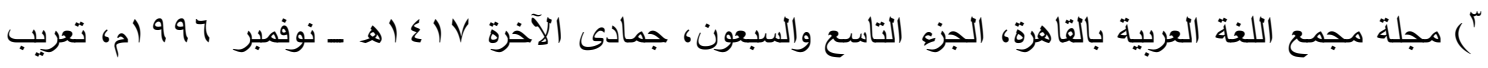

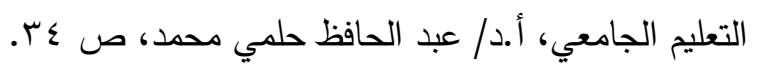

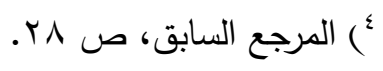




\section{حولية كلية الدعهوة الإسلامية بالقاهرة}

كئالتكوين اللغوي للدعاة وأثره في تجديد الحطاب الديني

فيك، لا بغرض الحصول على شهادة:

r. عليك بكتب الأدباء المحدَثين الهاضمين للغة، كالأساتذة: مصطفى لطفي المنفلوطي، ومصطفى صادق الرافعي، وعباس محمود العقاد، وطه حسين، وأحمد حسن الزيات، ومحمود محمد شاكر، وزكي مبارك، وعبد العزيز البشري، ومحمود الطناحي، وعبد الله فكري، ومحمد رجب البيومي، وقد جُمِعَت مقالات الطناحي تحت عنوان: (مقالات العلامة الدكتور محمود محمد الطناحي)، وللأستاذ محمود شاكر: (رسالة في الطريق إلى ثقافتنا) وهي من المهمات الثقافية للاعية.

ץ. واحرِ على قراءة المجلات القديمة كمجلة الرسالة، والعصور، والمقتطف، والههلال، وأبولُّو، والبلاغ، والثقافة لمحمد فريد أبي حديد، وغيرها، ولا تقل بتهكم واستعلاء : إنها مجلات أو جرائد! كأنك تُقارِنها بمجلات عصرنا الراهن، فليست مجلاتهم كمجلاتنا، ولا كُتَّابهم كُكتَّابنا!. ع. وإنتقِل إلى أصول الأدب، فاقرأ أدب الكاتب لابن قتيبة، أو الكامل للمبرد، أو البيان والتبيين للجاحظ، أو النوادر لأبي علي القالي، أو رسائل الجاحظ التي حققها الأستاذ عبد السلام هارون في مجلدات أربعة، فياله من إمتاع ومؤانسة!. 
المبحث الخاهم

\section{آثار التمكُُّ هن العربية في تجديد الفطاب الديني}

وفيه ثلاثة مطالب:

\section{المطاب الأول \\ إحياء العربية}

تمكُّن الدعاة من علوم العربية يُسْنِمُ في نشر العربية وإشاعتها في لغة التخاطب بين فئات المجتمع المختلفة، خصوصًا وهُم الخطباء والوعاظ الذين يُقْبِون على الناس بالنصح والإرشاد أيام الجُمَع والمناسبات، ويسهم كذلك في تصحيح المفاهيم المغلوطة عن اللغة، فإذا قلت لطالب كلية شرعية لا يصلي: (الصلاة واجبة). قال لك: ما الجديد في ذلك؟ أنا أعرف أنها واجبة، فكلامك لغو. ولم يَذْرِ أنَّ أغراض الخطاب لا تحصر في إفادة المخاطَب شيئًا يجهله، بل يشمل كذلك قَصْد المتكلِم إفادة المخاطَب أنه عالم بالحكم، فحينما يقول الأستاذ لطالب ينتظم في حضور دروسه: أنت تحضر كل دروسك، فلا يُقصد به إعلام الطالب بفائدة يجهلها، وإنما يُعْلمُهُ أنه عالم بأنه منتظم في دراسته، وهذا يسمى لازم فائدة الخبر ، ويسمى الأول فائدة الخبر • ولم يَذْرِ كذلك أنَّ الكلام قد يخرج على خلاف مقتضى الظاهر لاعتبارات: 1) فقد يُنَّل العالم بالثي منزلة الجاهل به، فُيُلقَى إليه الخبر وإن كان عالمِاِ بفائدة الخبر

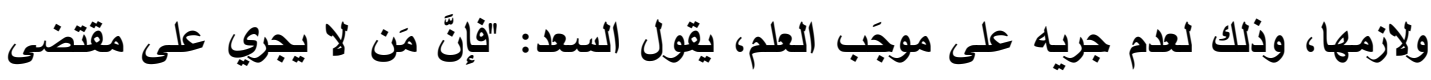
علمه هو والجاهل سواء، كما يقال للعالم تارك الصلاة: الصلاة واجبة، وتتزيل العالم بالثيء منزلة الجاهل به لاعتبارات خطابية كثير في الكلام"()، وقولك للذي لا يصلي: (الصلاة واجبة) من هذا الباب، فلعدم عمله بمقتضى علمه المفيد وجوب الصلاة عليه نُزِّل منزلة الجاهل به، "وإنما جاز تنزيل العالم منزلة الجاهل عند انتفاء جريـه على موجَب العلم تعييرًا له وتقبيحًا بحاله؛ لأنه إذا كان عالمًا بوجوب الصلاة، وكان تاركًا لها، وقيل له: الصلاة واجبة، كان في إلقاء الخبر إليه إثشارة إلى أنه هو والجاهل سواء؛ لأنه لا يتصور تركها إلا من الجاهل، وفي هذا من التوبيخ ما لا يخفى"(ع).

$$
\begin{aligned}
& \text { ') مختصر المعاني، سعد الدين التقتازاني، ص عـ } \\
& \text { r) حاشية الدسوقي على مختصر المعاني، /107. 1. }
\end{aligned}
$$




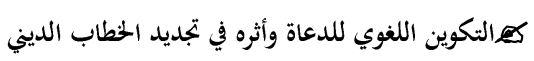

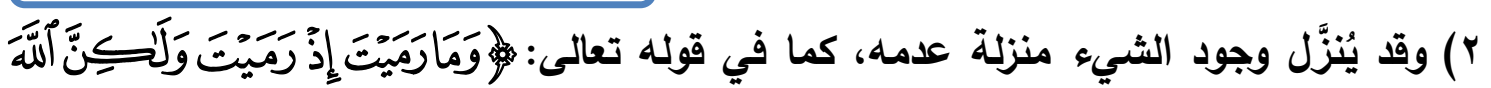

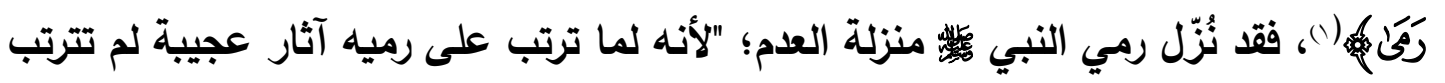
على فعل غيره من البثر عادة، نُّزل ذلك الرمي منزلة العدم لقلته؛ لما ترتب عليه" (().

إنَّ إحياء العربية لا يقتصر على ضبط أواخر الكَلٍِ العربية، وإنما يعني "إحياء الخصائص

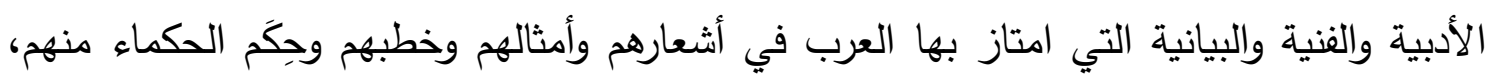

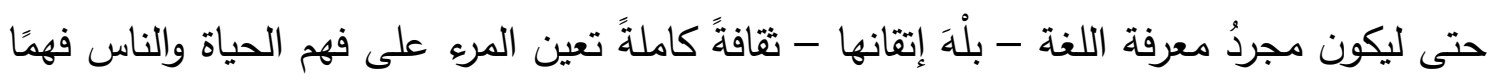

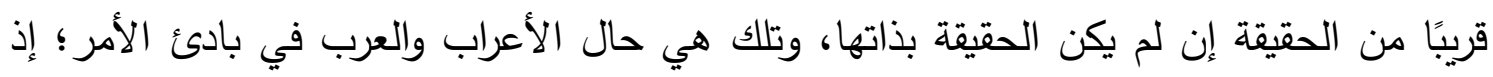

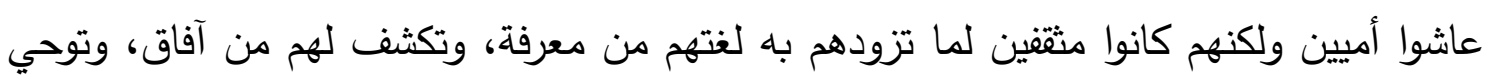

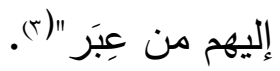

وبإتقان الدعاة للعربية، وتمثُلهم بها، وذوبانها في أنفسهم، تُحيا العربية إحياءً لا ينحصر

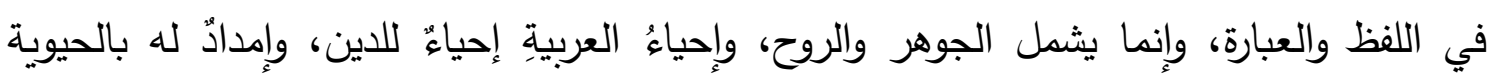
والفاعلية.

$$
\begin{aligned}
& \text { ') سورة الأنفال، من آية VV }
\end{aligned}
$$

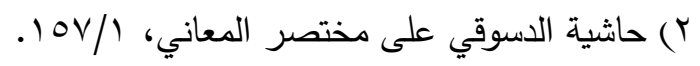

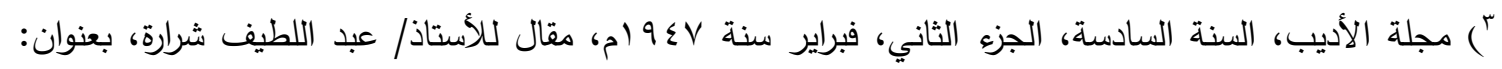

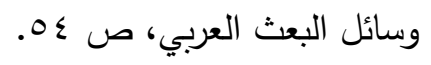




\section{الاطلب الثاني}

\section{الفهم المنضبط لنصوص الشارع}

إنَّ الوقوف على علوم اللغة العربية تَنْصِمُ مراعاتُها الذهنَ عن الخطأ في فهُم مراد الثارع،

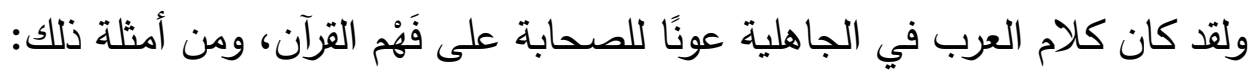

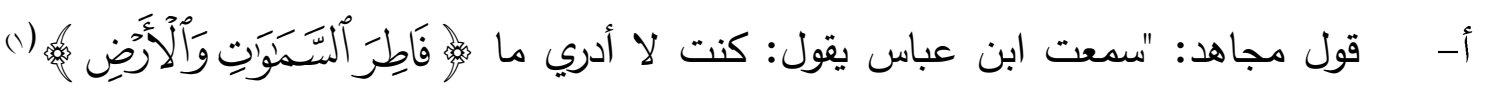

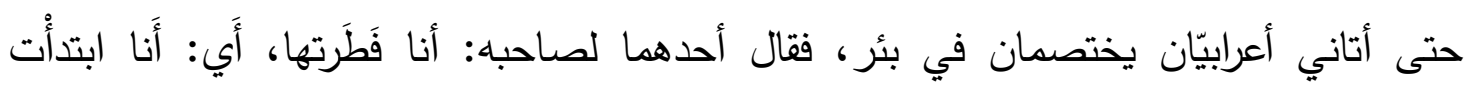

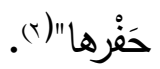
ب- - مقول ابن عباس: "ما كنت أدري ما قوله:

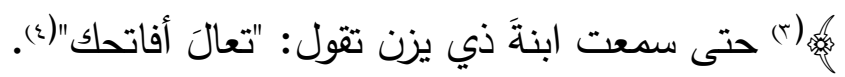

وهذا يشير إلى أنَّ فهم كتاب الله لا يكون إلا بالتعقق في العربية؛ فإن "للتعمق في اللغة

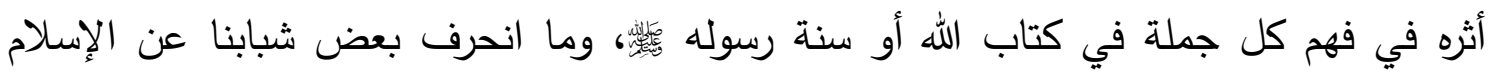

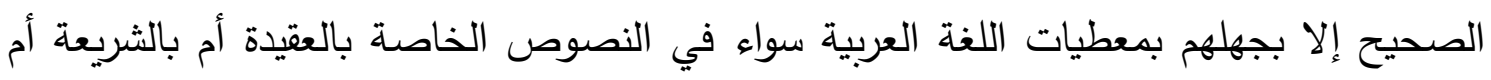
بالقصص القرآني"(o).

ويحكي الأستاذ الدكتور "محمد المختار المهدي" موقفًا حدث معه يُيِّن أثر الجهل باللغة

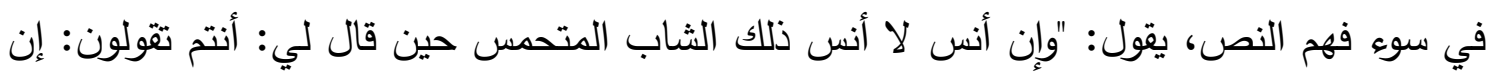

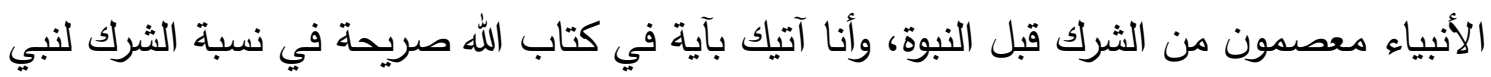

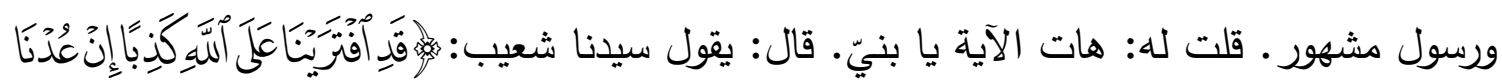

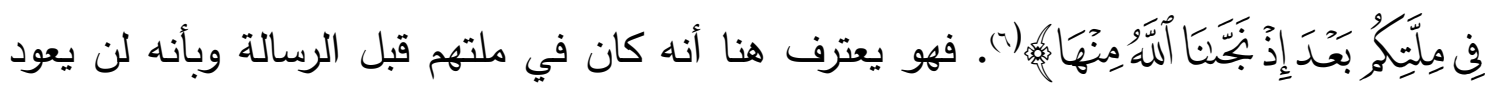
إليها. قلت له: ما أجهلك بلغة قومك يا بنيّ. إذا كان فهمك هذا صحيحًا، فكل الرسل - وليس

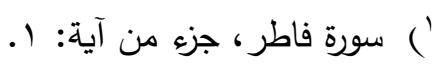

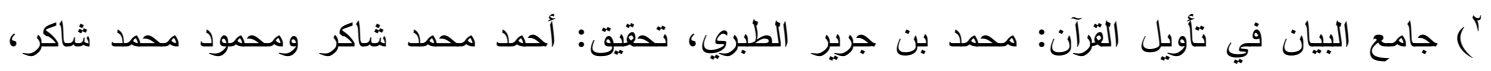

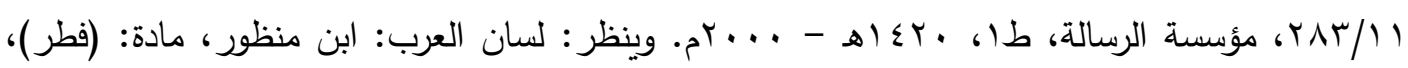

$$
\begin{aligned}
& .07 / 0
\end{aligned}
$$

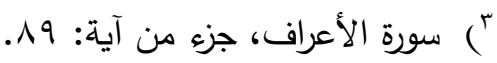

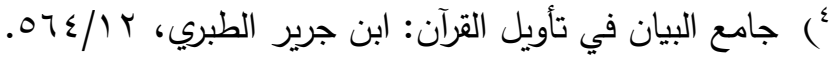

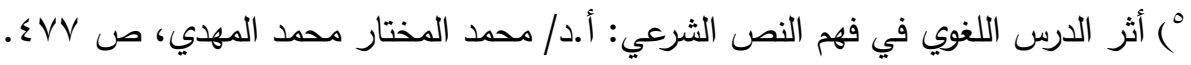

$$
\begin{aligned}
& \text { ") سورة الأعراف: من آية 19. }
\end{aligned}
$$




\section{حولية كلية الدعهوة الإسلامية بالقاهرة}

كعبالتكوين اللغوي للدعاة وأثره في تجديد الحطاب الديني

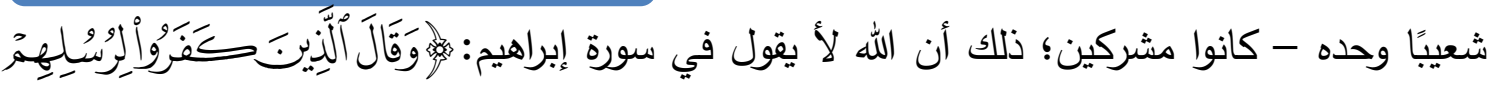

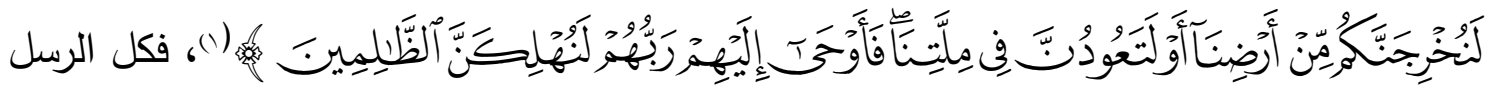

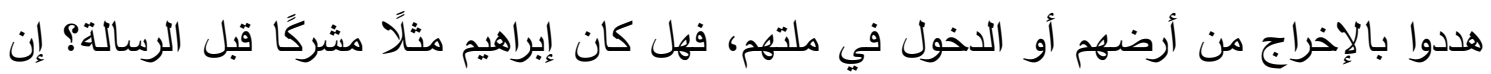

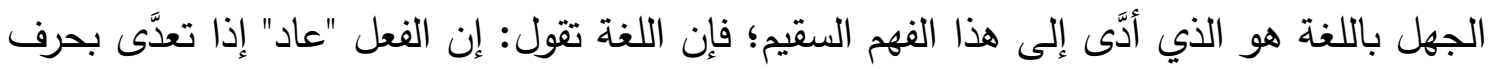

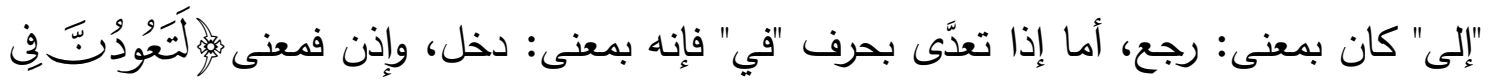

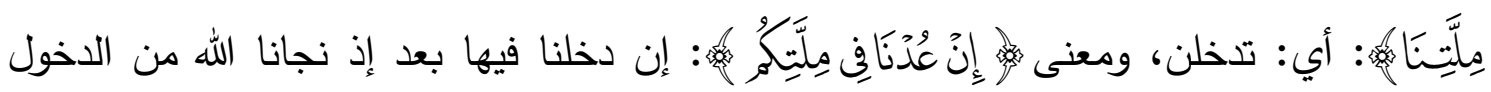
فيها" () () (1)

فإن قلت: أيكفي في فهم نصوص القرآن والسنة الرجوع إلى كتب الغريب والمعاجم؟ قلت: لا

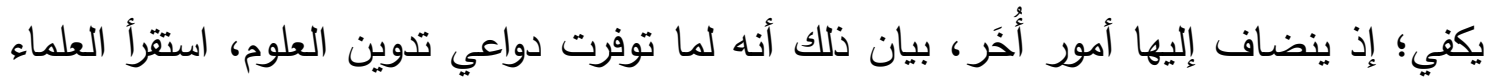

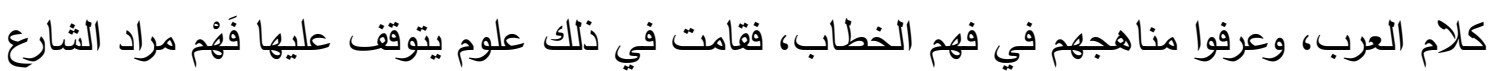

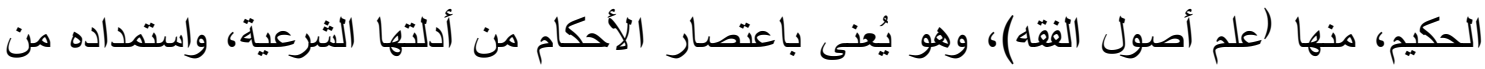

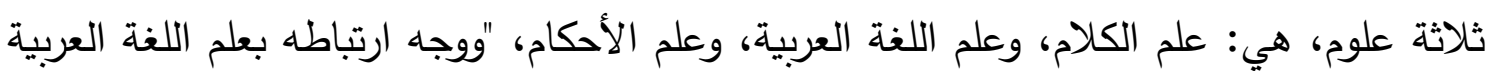

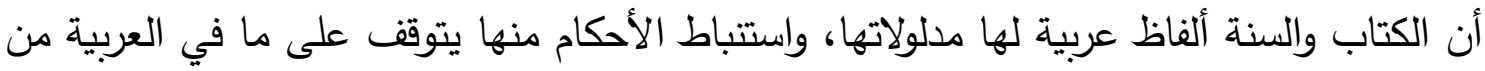
حقيقة ومجاز، وعموم وخصوص، ومطلق ومقيد، ومنطوق ومفهوم، وغير ذلك، وهذه هي المعروفة عند الأصوليين بالمبادئ اللغوية"(().

ومن مُنَّارات الفخر أنَّ للأصوليين نظرًا زائدًا إلى المباحث اللغوية عن نظر اللغويين، يقول

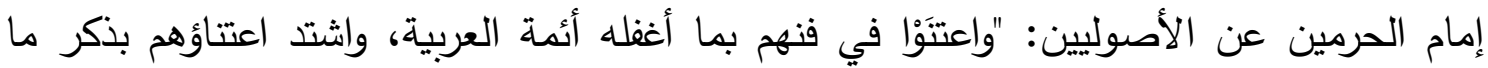
اجتمع فيه إغفال أئمة اللسان، وظهور مقصد الشرع" (2)، ويقول تقي الدين السبكي في سياق ردّه

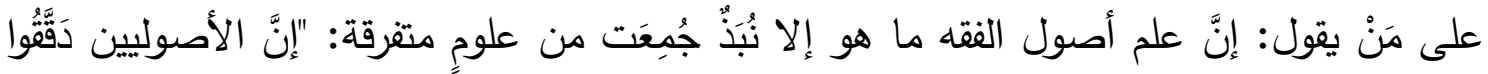

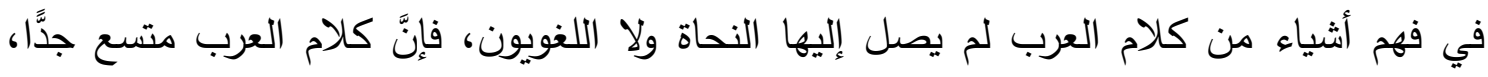

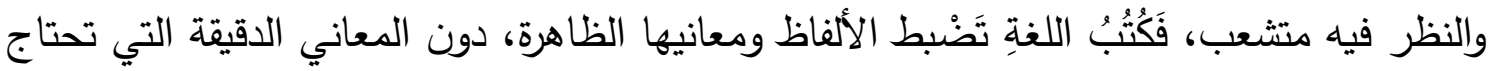

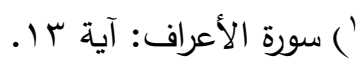

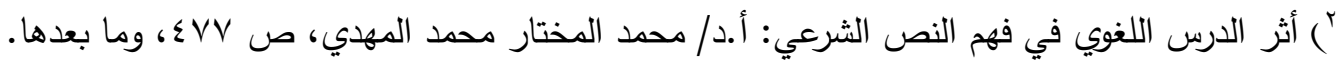

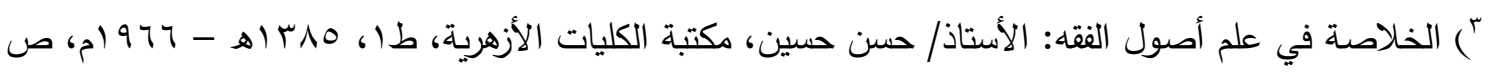

צ) البرهان في أصول الفقه: إمام الحرمين الجويني، تحقيق: صلاح بن محمد بن عويضة، دار الكتب العلمية

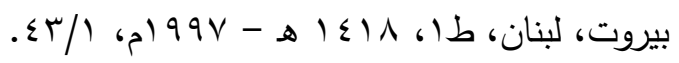


كيك التكوين اللغوي للدعاة وأثره في تجديد الخطاب الديني

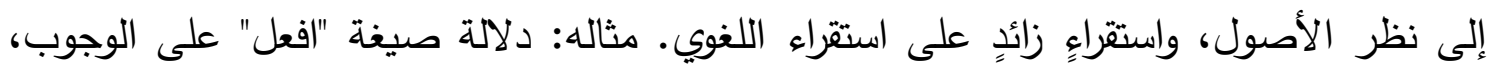

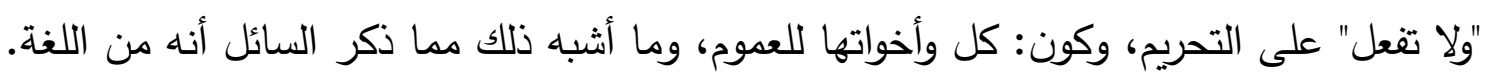

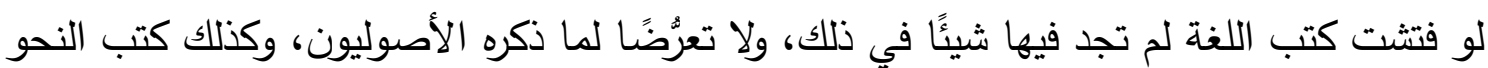

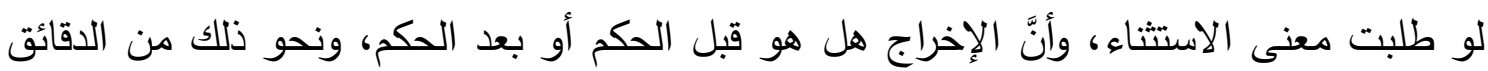

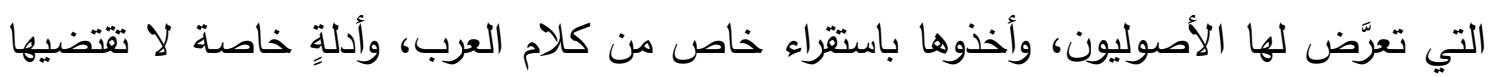

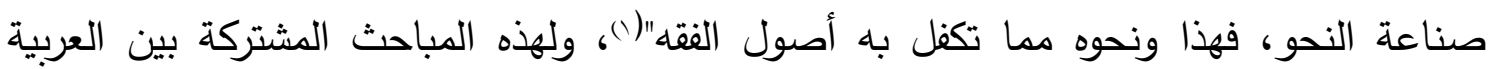

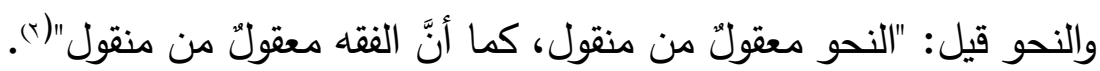

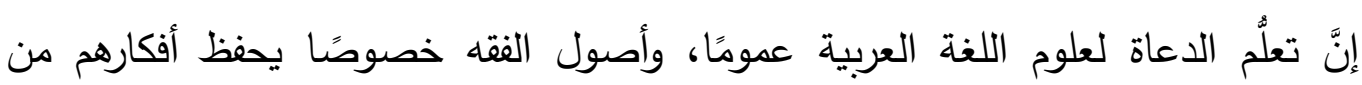
الانحراف أو التميُّع في فهم دلالات الألفاظ، وبذلك يتكوّن للدعاة مناعةٌ قويةٌ تحفظهم من استخراج

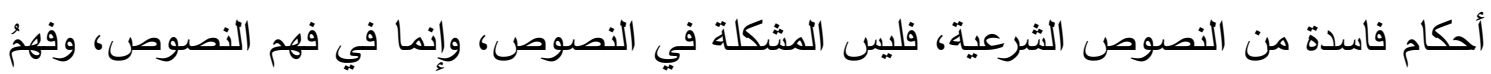

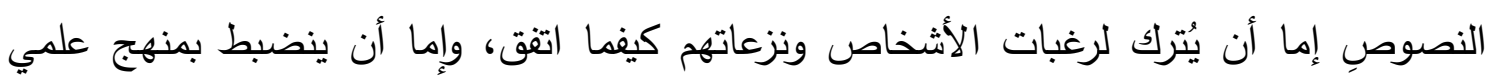

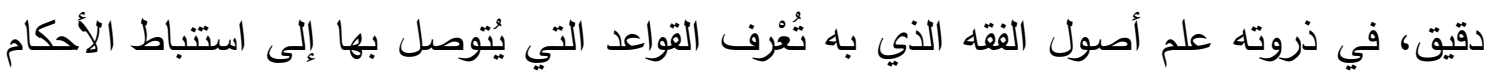

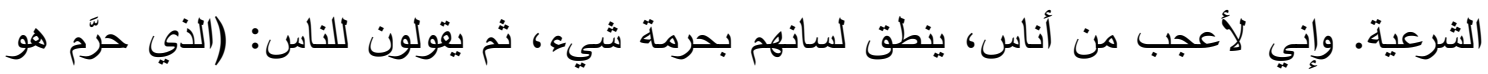

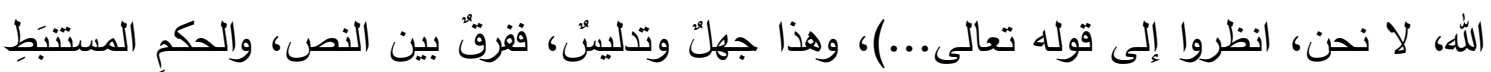

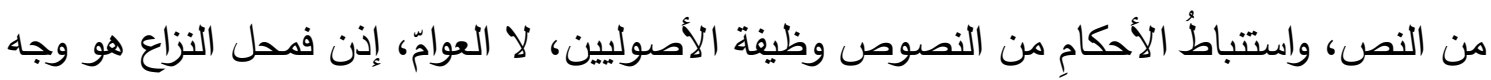
دلالة النصوص، لا النصوص في حد ذاتها.

وفيما يأتي سأذكر نموذجًا يُبيّن الفرق بين الفكر المنضبط بالمنهج العلمي الدقيق، والفكر

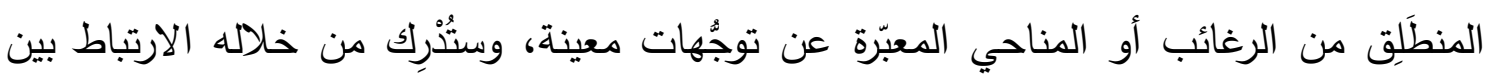

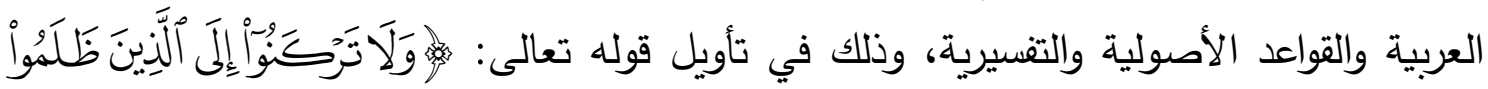

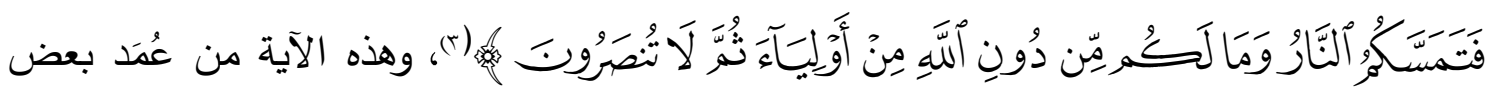
التيارات الفكرية في الخروج على المجتمعات بالترويع والإفساد، فلنظظر إلى التأويلين الآتيين:

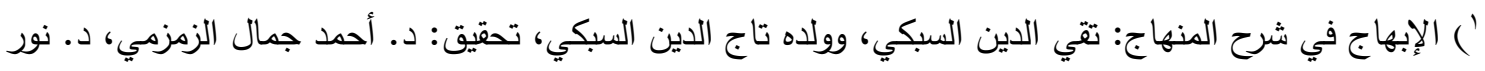

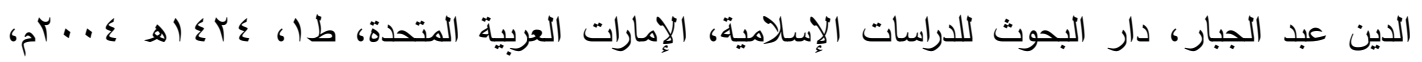

$$
.10 / 1
$$

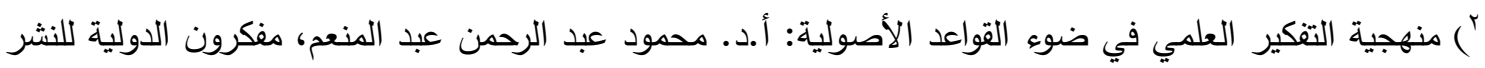

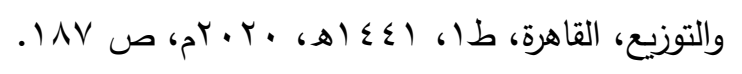

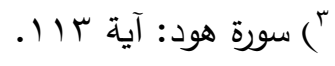




\section{أ- التأويل غير المنضبط: - أن}

يقول في تأويلها: "لا تستندوا ولا تطئنوا إلى الذين ظلموا، إلى الجبارين الطغاة الظالمين،

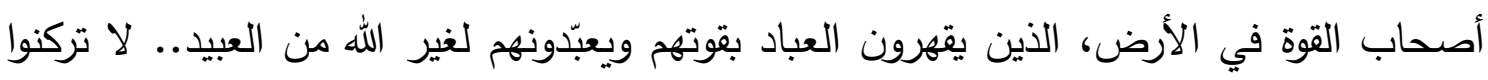

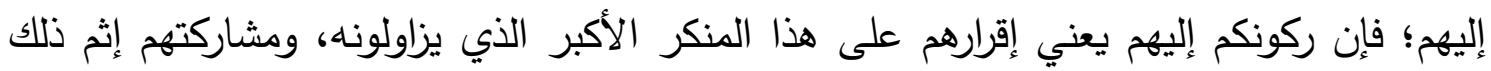

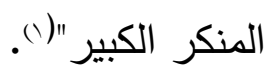

يُفسّر (الذين ظلموا) بأنهم الجبَّارون، الطغاة، أصحاب القوة في الأرض، الذين يقهرون

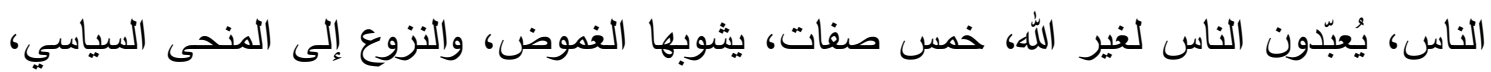

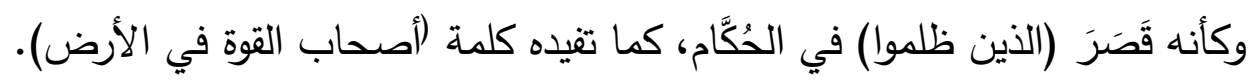
وعلى نفس المنهج في الغموض، يقول كاتِبّ بعد أنْ أورد هذه الآية مع ما يقاربها: "وهذه

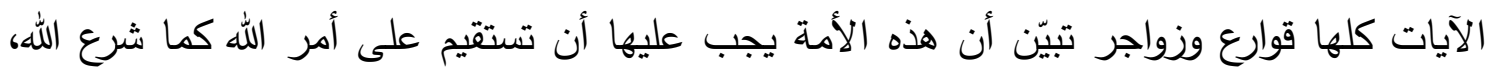

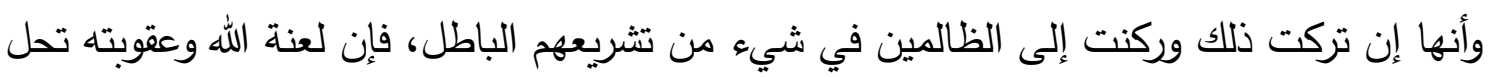
بهم كما حلت بالأمم السالفة" ().

هكذا يقول دون أن يُحدّد المراد بالظالمين، وخطورة ذلك أنه لا يوجد إنسان غير معصوم

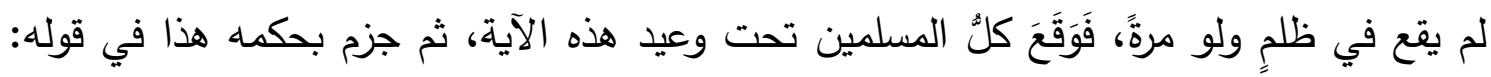

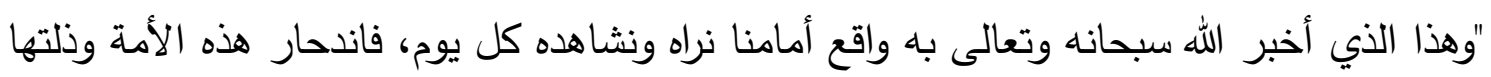

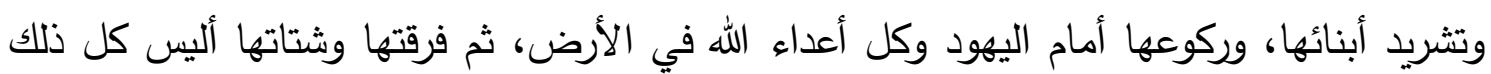

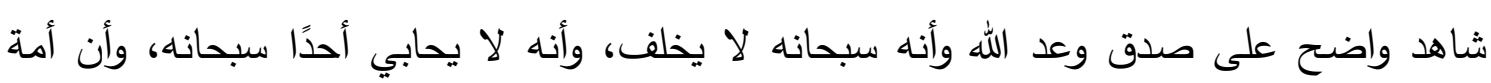

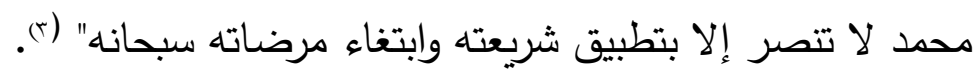

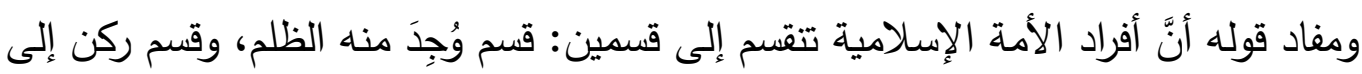

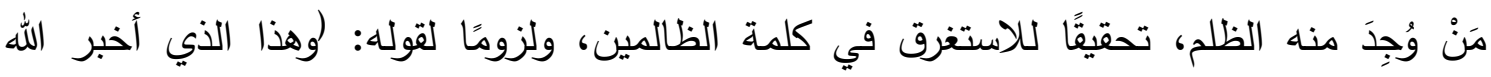

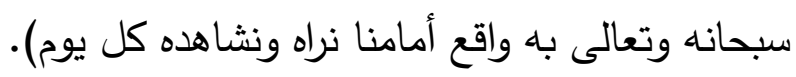

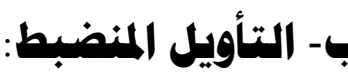

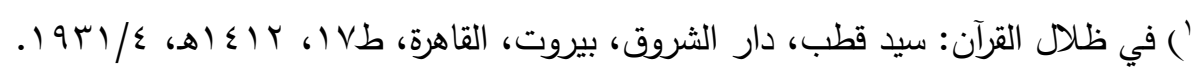

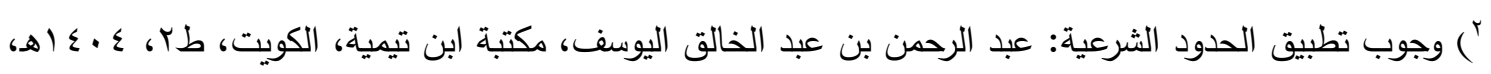

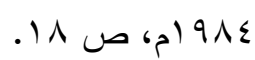
r ( المرجع السابق، الصفحة ذاتها. 
يتبين من خلال النقاط الآتية:

أولًا: تعريف الركون لغة: هو "السكون إلى الثيء، والميل إليه"((). ثانياً: توجيه الخطاب في الآية:

الخطاب في الآية "لأتباع الكفرة، أي: لا تركنوا إلى القادة والكبراء في ظلمهم، وفيما

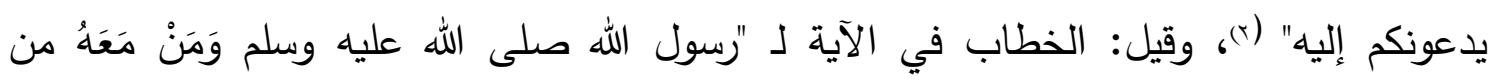

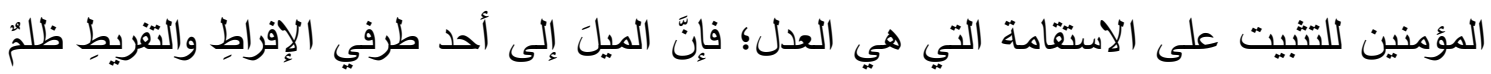

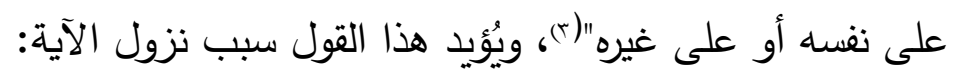

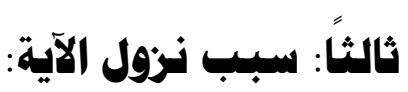

"قال بعض أهل التأويل نزل قوله:

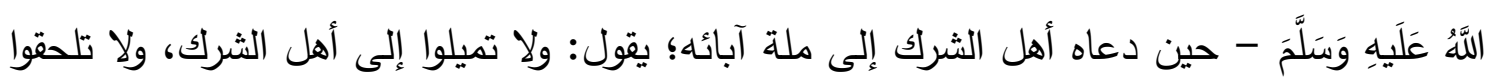
بهم"(s)

\section{رابعاً: الركون المنهي عنه:}

فُمَّرِ بالتأويلات الآتية:

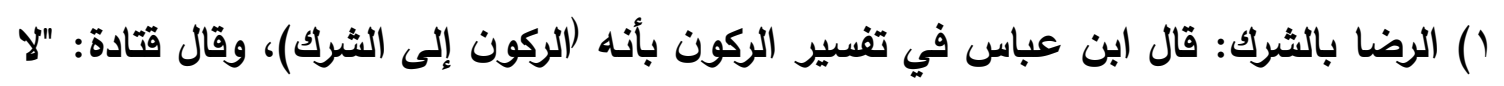

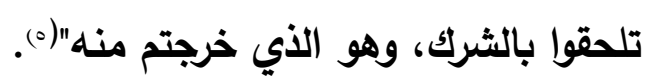

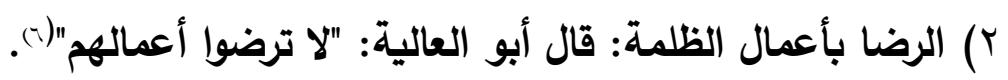

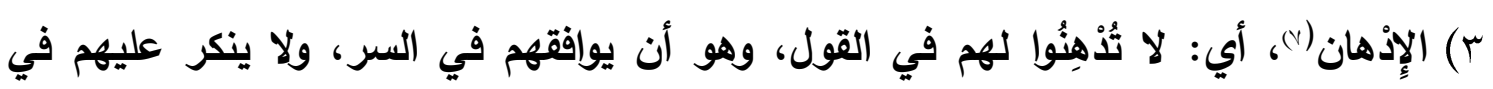

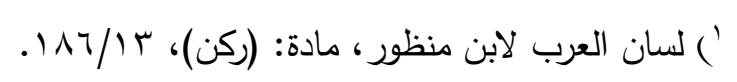

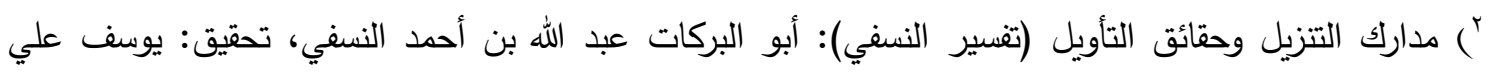

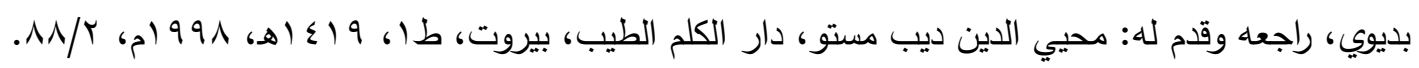

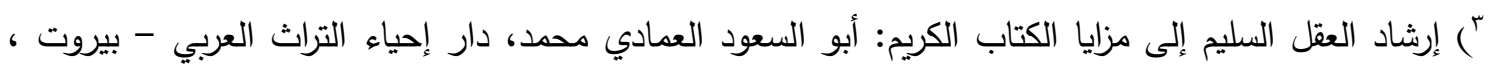

$$
\text { . }\{\leqslant 0 / \varepsilon
$$

؛) ت تفسير الماتريدي (تأويلات أهل السنة): محمد بن محمد بن محمود، أبو منصور الماتريدي، تحقيق: د. مجدي

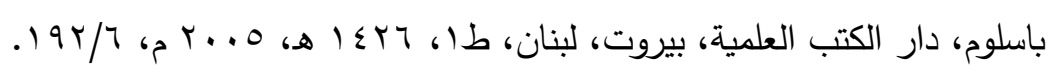

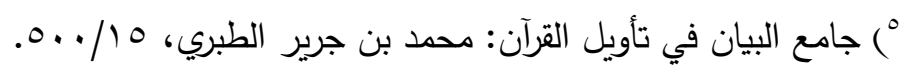
") المرجع السابق، الصفحة ذاتها.

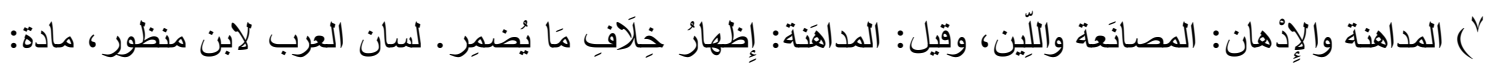




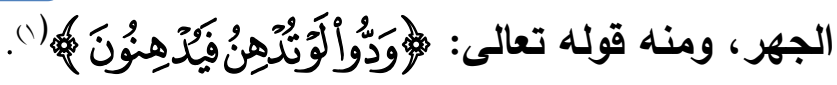

يقول الفخر الرازي: "قال المحققون: الركون المنهي عنه هو الرضا بما عليه الظلمة من الظلم، وتحسين تلك الطريقة وتزيينها عندهم وعند غيرهم، ومشاركته في شيء من تلك الأبواب، فأما مداخلتهم لدفع ضرر أو اجتلاب منفعة عاجلة، فغير داخل في الركون"(؟).

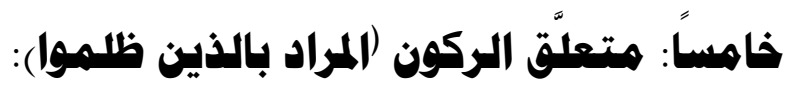

هنا ثلاث إشارات:

الأولى: فرقّ بين (الظلم) و (الركون إلى الظلم)، فعقاب الركون إلى الظلم دون عقاب

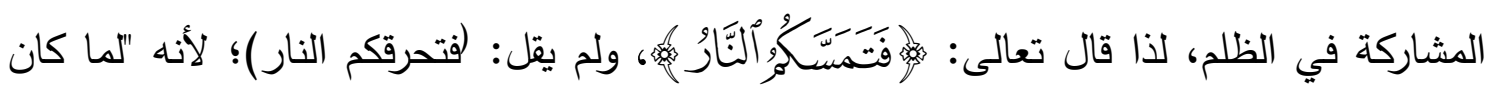
الركون إلى الظالم - وهو الميل إليه والاعتماد عليه - دون مشاركته في الظلم، وجب أن يكون العقاب عليه دون العقاب على الظالم، فأتى بلفظ المسّ الذي هو دون الإحراق والاصطلام" (ب).

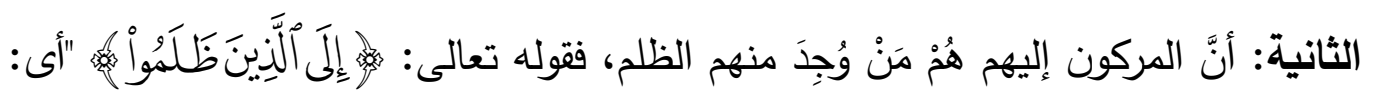

إلى الذين وُجِدَ منهم الظلم، ولم يقل: إلى الظالمين"(().

الثالثة: المراد بـ "الذين ظَلَمُوا هنا هم الكفار، وهو النص للمتأولين، ويدخل بالمعنى أهل

المعاصي" (0) (20)

إذن فبإدراك الداعاة للعلوم العربية، ووقوفهم على المبادئ اللغوية من مباحث العموم والخصوص وغيرها من قواعد تفسير النصوص المبيَّنة في علم أصول الفقه، يتبيَّن لهم أنَّ الركون هنا ليس على عمومه، بل خاصٌُ بالرضا بالظلم، وأنَّه خُصَّ بالكفار، وإنْ دخل فيهم أهل المعاصي

$$
\text { (د) }
$$

') تفسير الماوردي (النكت والعيون): أبو الحسن علي بن محمد البغدادي، تحقيق: السيد ابن عبد المقصود بن عبد

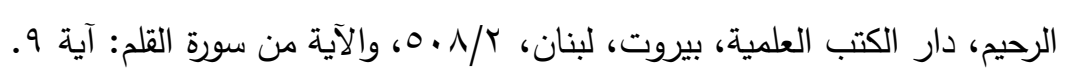

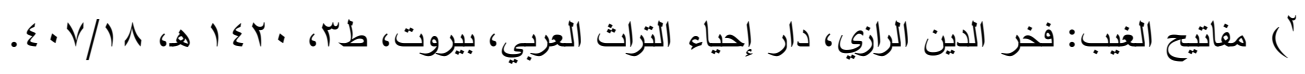
r رفيق العجم، تحقيق: د. علي دحروج، نقل النص الفارسي إلى العربية: د. عبد الله الخالدي، الترجمة الأجنبية:

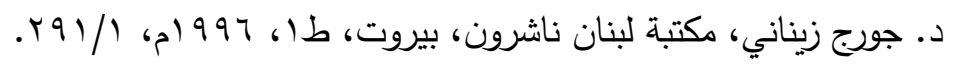

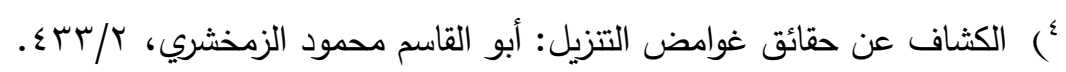

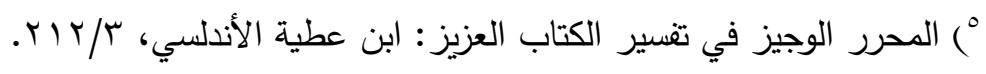


كأكبالتكوين اللغوي للدعاة وأثره في تجديد الخطاب الديني

من المؤمنين. أما إطلاق الأحكام بناءً على عموميَّة الألفاظ، دونما تقريق بين عام وخاص، ومطلق ومقيد، ومجمل ومبين، فَفِنْ دُفْسِدات التأويل، وتحميل الألفاظ ما لا تحتمله من المعاني، فكلٌّ صاحبِ هوى يُحمّل اللفظ بما يُسوّغ لله توجُّهه، وتُعَّر المعاني بحسب التأويل الشخصي، لا بحسب ونب التأويل الوضْعِ، مع أن القاعدة تقول: الاستعمال صفة المتكلم، والحمل صفة السامع، والوضْعَ قبلهما.

ومن هذه الطريق تتموُ المجتمعات، ويقلُّ الثغب، فـ "إذا أردنا أن نلحق بركب العلم،

وندخل بالدرس العربي مجال العصر الحديث، فأول ما ينبغي العناية به ضبط مصطلحات فروع المعرفة، وجعل اللغة العربية لغة دقيقة في شتى النواحي، قادرة على استيعاب الأفكار، مبرأة من

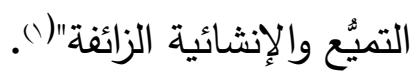

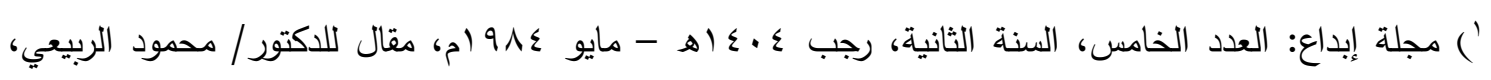

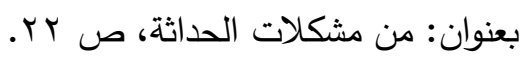




\section{المطلب الثالث}

\section{تمريز الفهم الصهيح للعقيدة الإسلاهية}

عدَّ الإمام السنوسي الجهل باللسان العربي من أصول الكفر السبعة()، ربما أثارت مقالته

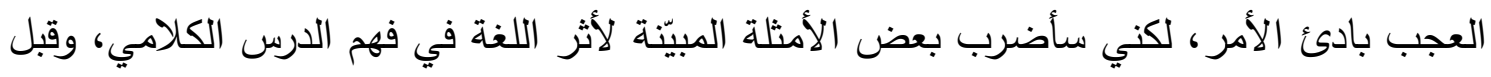

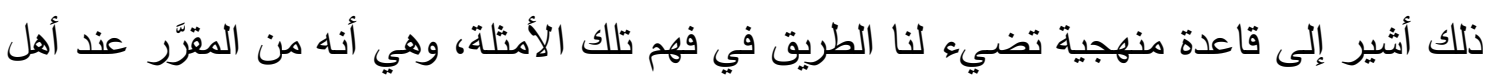

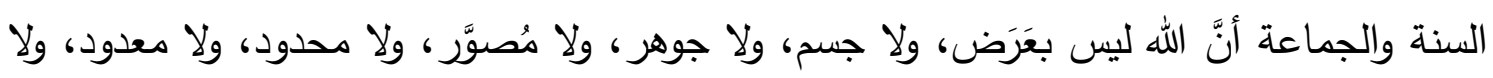

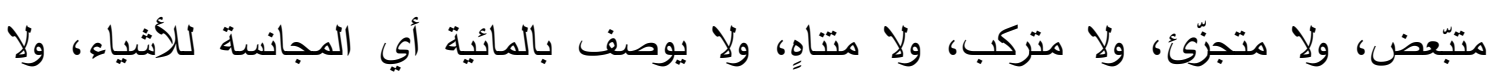

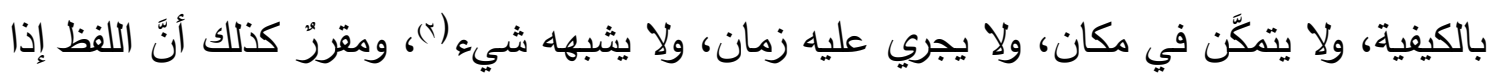

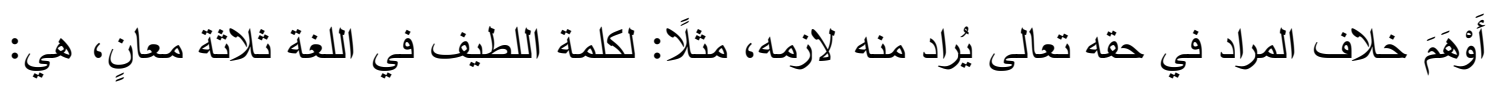

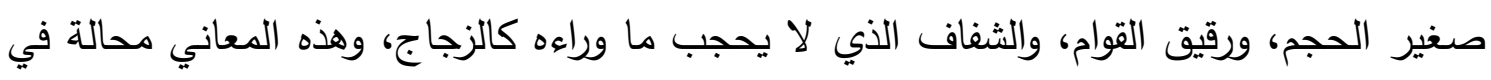

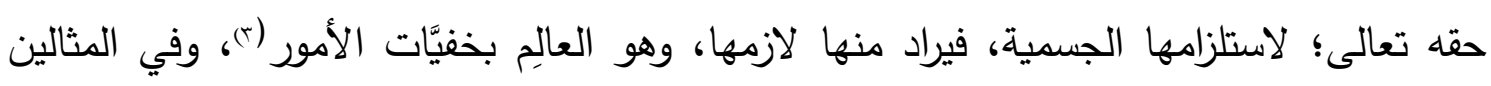
الآتيين سيتبيّن لك أثر الجهل بعلوم العربية في الانحراف في فهم العقائد:

المثال الأول: قضية الإسناد، وبيانها أنَّ إسناد الحوادث والكائنات إلى الله على سبيل

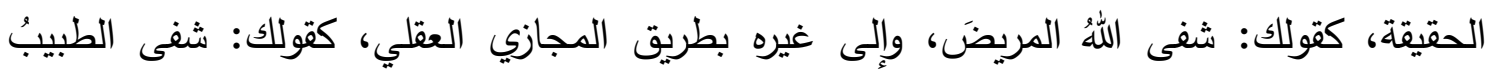

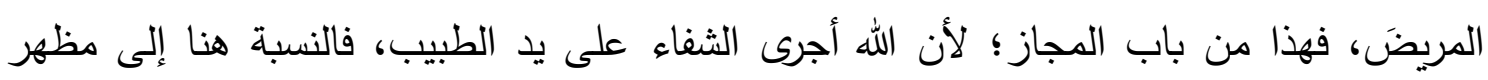

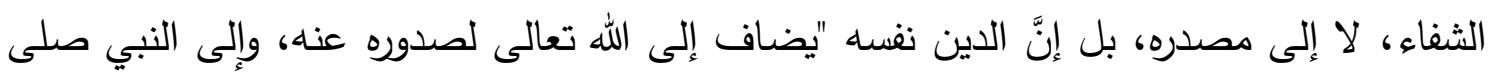

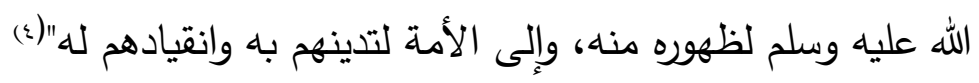
وبذلك يتبين أنَّ الإسناد إما أن يكون لمصدر الثيء، أو مظهره، وأن الأول على سبيل

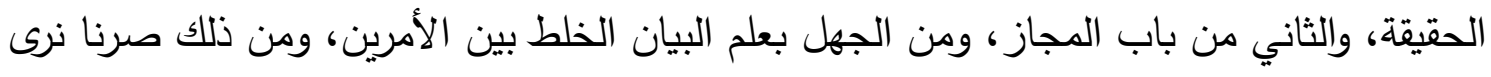

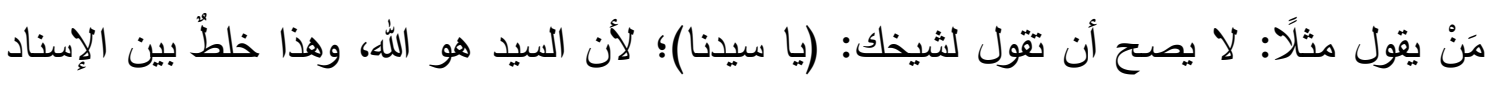

(1) ينظر : المواهب اللدنية شرح المقدمات السنوسية: أبو إسحاق إبراهيم السرقسطي، مكتبة مصطفى البابي الحلبي

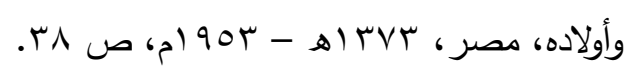

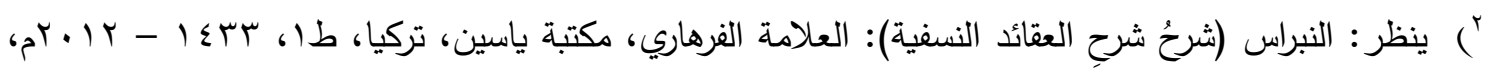

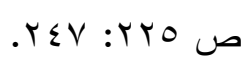
r بنظر : حاشية على الخريدة البهية: سيدي أحمد الصاوي، مطبعة مصطفى البابي الحلبي وأولاده، القاهرة،

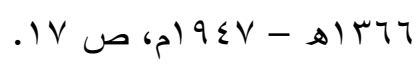

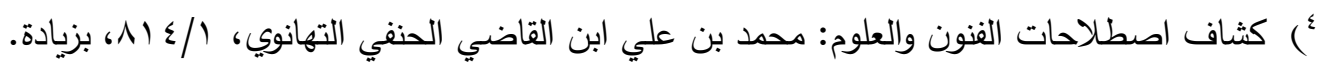




\section{هولية كلية الدعوة الإسلاهية بالقاهرة}

كبع التكوين اللغوي للدعاة وأثره في تجديد الحطاب الديني

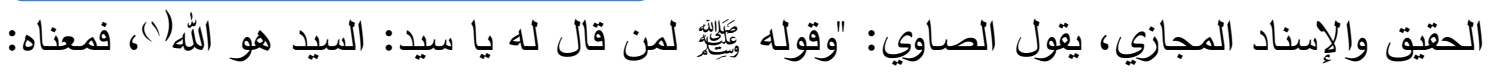
أنه الحقيق بالسيادة، وإطلاقها على غيره إنما هو بطريق العارية، فالمقصود منه إعلام الجاهل بالحقيقة"(؟)، أي: هي لله بطريق الحقيقة، وإلى غيره بطريق المجاز ، والمقصود من الحديث إعلام المخاطَب بالمعنى الحقيقي.

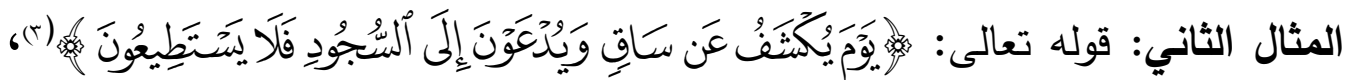

"الجمهور على أنَّ الكشف عن الساق عبارة عن شدة الأمر وصعوبة الخطب(ع)، فمعنى يَّة يَّم"

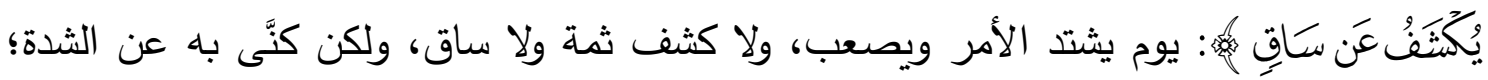
لأنهم إذا ابتلوا بشدة كشفوا عن الساق، وهذا كما تقول للأقطع الثحيح: يده مغلولة، ولا يد ثمة ولا غل، وإنما هو كناية عن البخل، وأما مَنْ شَبَّهَ فلضيق عَطَنِه، وقلة نظره في علم البيان، ولو كان

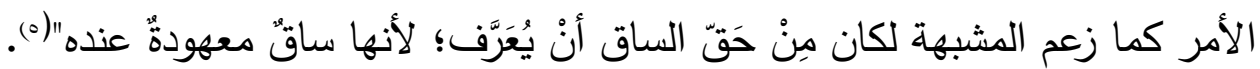
تأمَّلْ قول النسفي: (وأما مَنْ شَبَّةَ فلضيق عَطَنِه، وقلة نظره في علم البيان)، فإنها يدلُّك على أنَّ للجهل باللغة أثرًا في الوقوع في معاطن التشبيه والتجسيم، وأنَّ العلوم مترابطة، فلا تستقيم دراسة علم الكلام والأصول مثلًا قبل دراسة العربية من نحو وصرف ومعانٍ وبيان وبديع، انظر لنر إلى قول بهاء الدين السبكي في ثرح تلخيص المفتاح) في علوم البلاغة الذي استعان عليه بنحوٍ من ثلاثمائة مُصَنَّف: "واعلم أني مزجت قواعد هذا العلم بقواعد الأصول والعربية.... وضمنته شييًا من القواعد المنطقية والمقاعد الكلامية والحكمة الرياضية أو الطبيعية"()، أي: الفلسفة الرياضية،

') أصل الحديث: عن مطرف قال: قال أبي: انطلقت في وفد بني عامر إلى رسول الله صلى الله عليه وسلم،

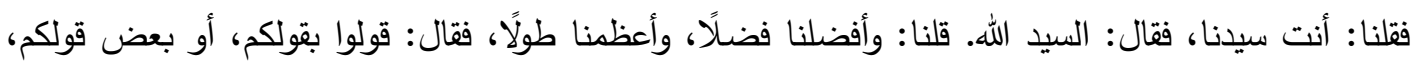

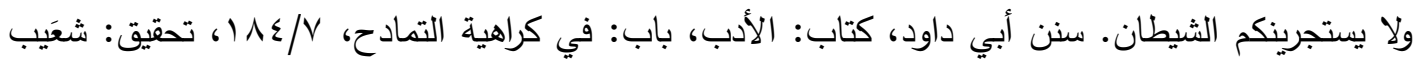

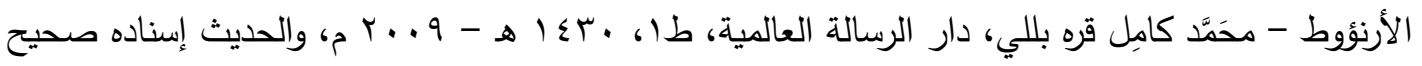
كما ذكر المحقق.

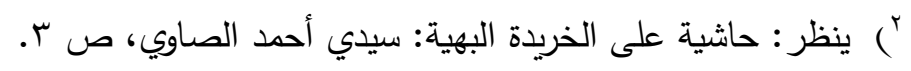

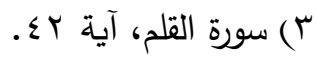

ع) للوقوف على طرائق أهل السنة في فهم النصوص الموهمة للتثبيه، ينظر : النظام الفريد بتحقيق جوهرة التوحيد:

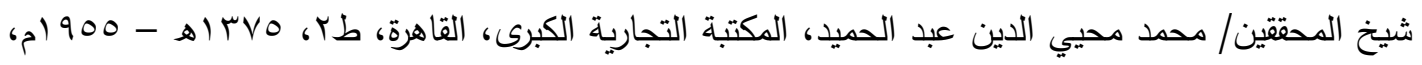

$$
\text { ص د ب ا ، وما بعدها. }
$$

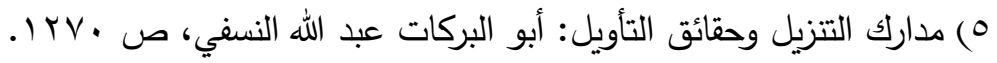

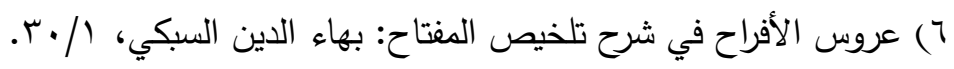


كع التكوين اللغوي للدعاة وأثره في تجديد الخطاب الديني

والفلسفة الطبيعية، إذ الحكمة قديمًا على ثلاثة أقسام، ثالثها هو الحكمة الإلهية.

فإن قلت: رأينا أنَّ الجهل باللسان العربي، إنْ لم يوصل إلى الكفر أوقع في الخبال

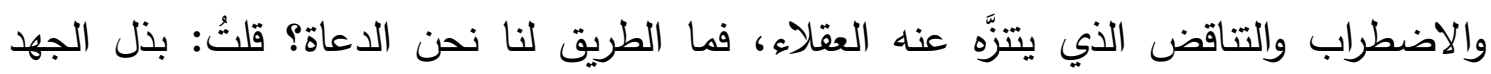

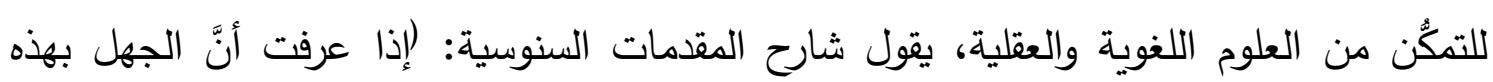

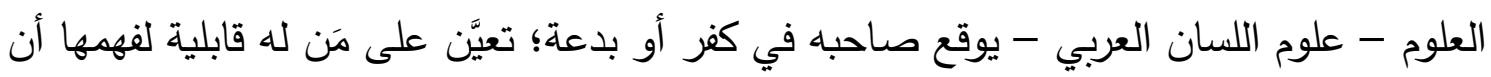

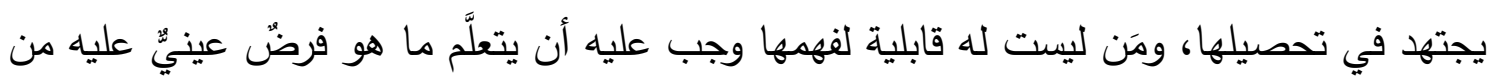
علم التوحيد)(')

أي: مَن لم يتعلم العربية ينبغي أن يعرف الدلائل الإجمالية العقلية، والكمالُ الجمعُ بين تعلُم اللغويات والعقليات، ومن الدواهي العظام في حياتتا الفكرية الجهل بهما معًا.

( ) المواهب اللدنية شرح المقدمات السنوسية: أبو إسحاق إبراهيم السرقسطي، ص ^ґ. 


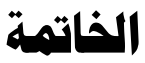

( ) العناية بالتكوين العلمي للأُعاة من الضرورات الدعوية؛؛ لِمَا يزخر به العصر الحاضر من

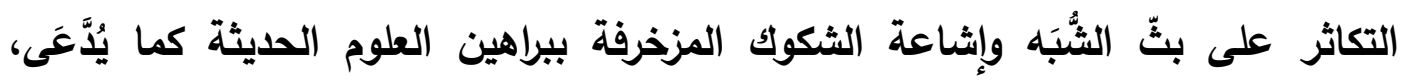

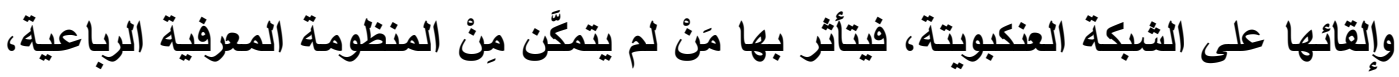
وما أكثرهم!

تتمازج المكوّنات العلمية للعقلية الدعوية من خلال أربعة مسالك، وهي: العلوم النقلية، والعقلية، والذوقية، والتجريبية.

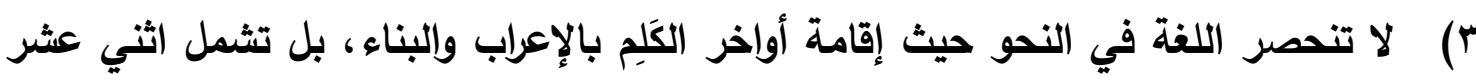

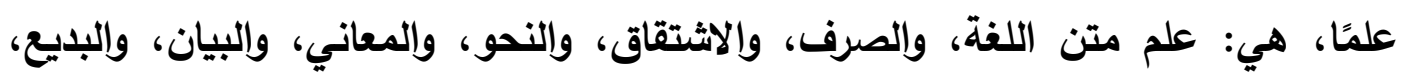

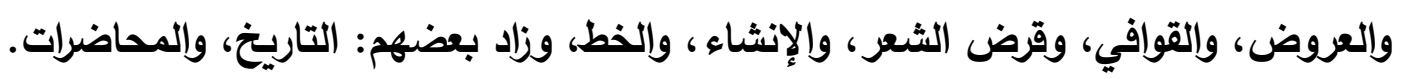

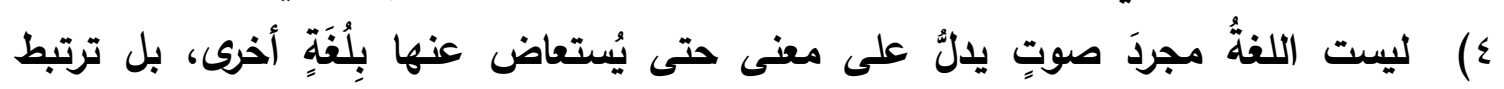

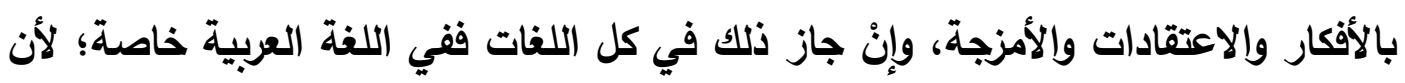

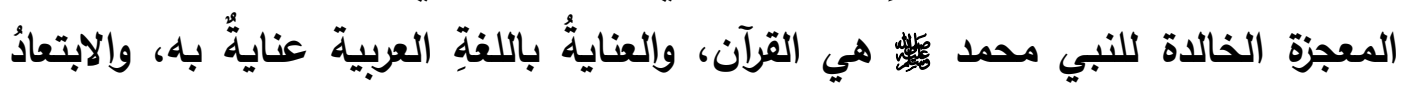

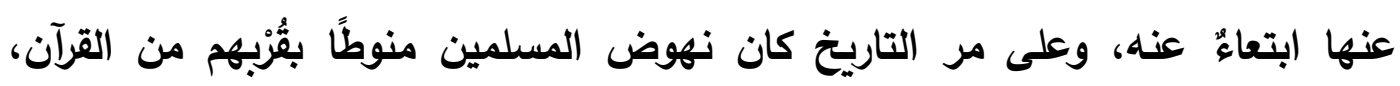

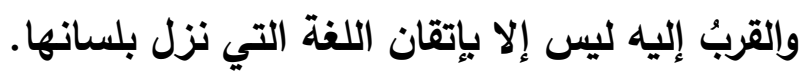

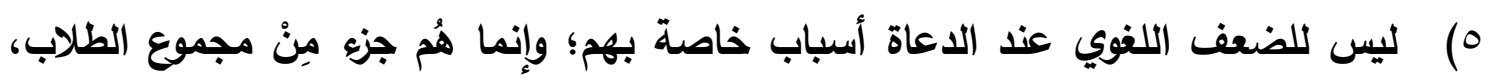

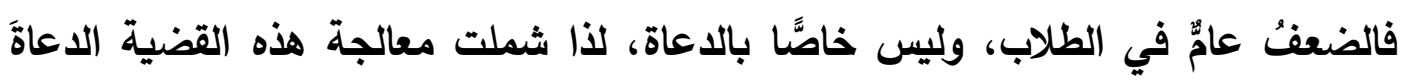
وغيرهم.

أعظم أسباب الضعف اللغوي هو تركيز النظام التعليمي على حفظ القواعد وإهمال الجانب

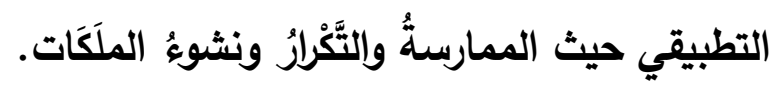

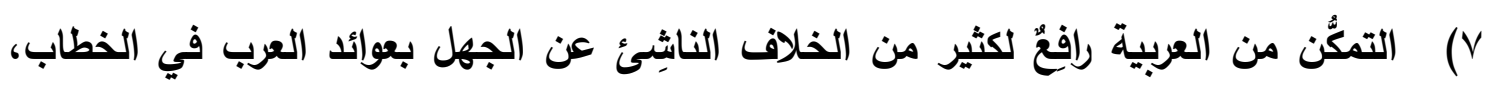

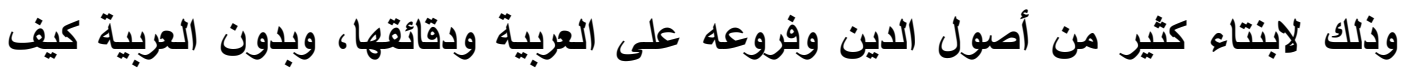

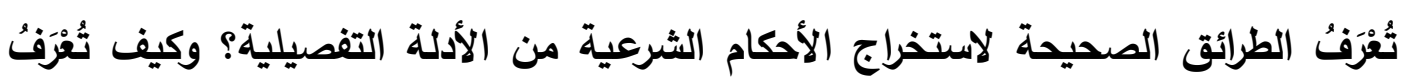

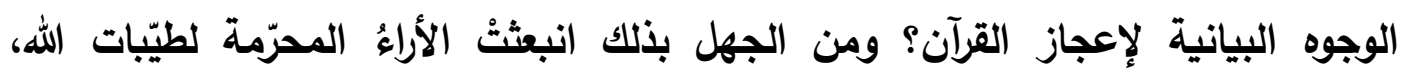

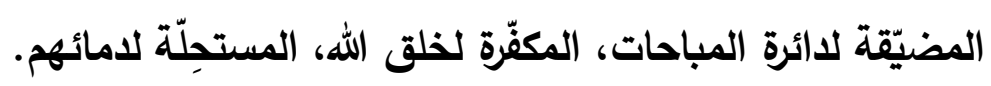




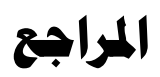

\section{أولاً: القرآن العظيم.

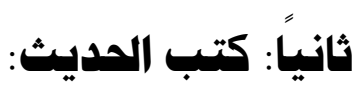

() سنن أبي داود، كتاب: الأدب، باب: في كراهية التمادح، تحقيق: شعَيب الأرنؤوط - محمَّد

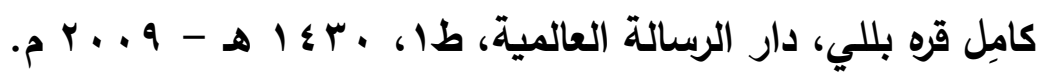

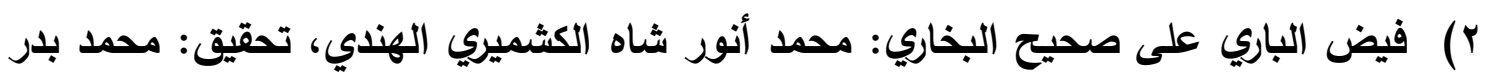

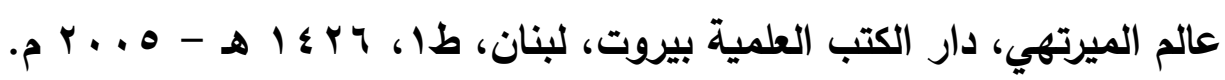

\section{ثالثاً: كتب التفسير.}

r) تفسير الماتريدي (تأويلات أهل السنة): محمد بن محمد بن محمود، أبو منصور الماتريدي،

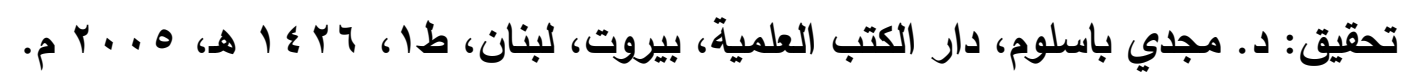

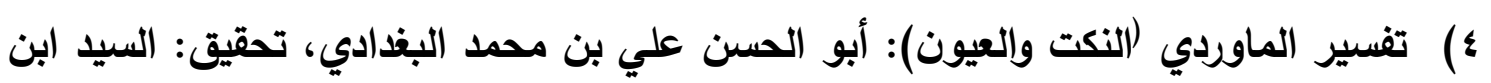

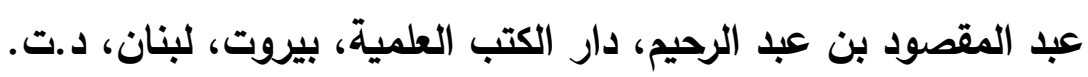

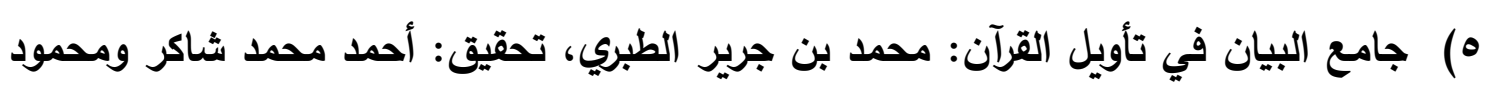

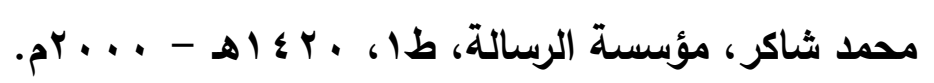

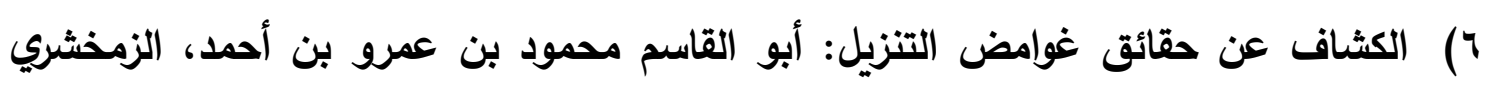

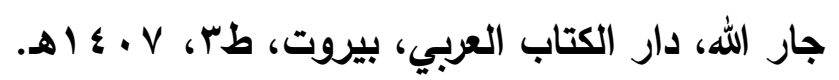

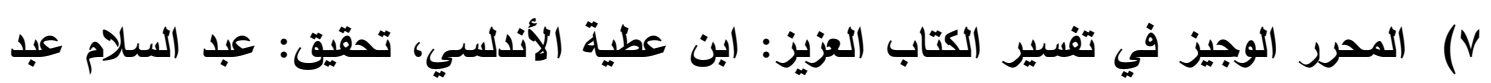

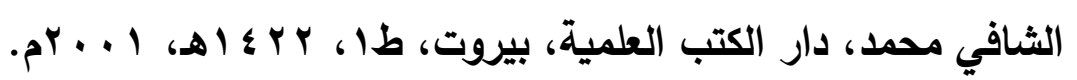

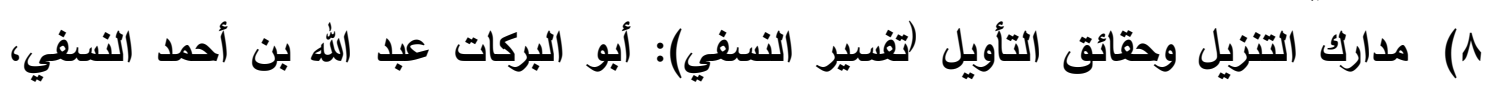

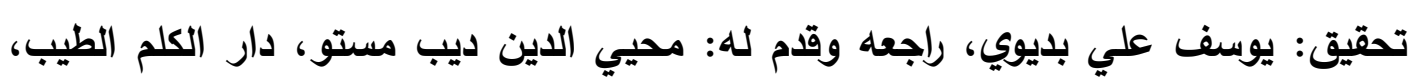

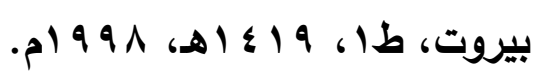

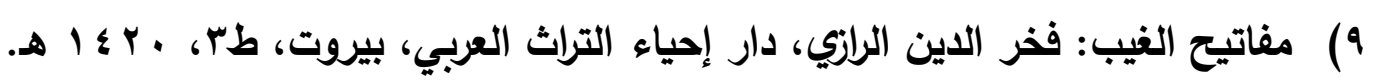
رابعاً: كتب علوم اللغة العربية:

• (1)تاريخ آداب العرب: الأستاذ/ مصطفى صادق الرافعي، مطبعة الاستقامة، القاهرة، طץ،

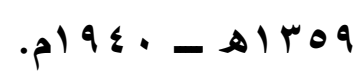

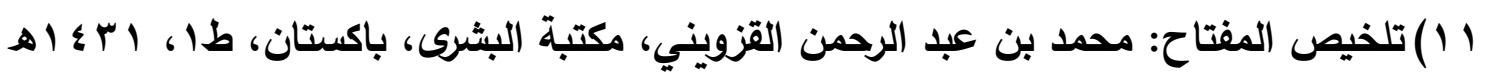

$$
\text { . } \text { p. }^{\prime} \cdot-
$$




\section{حولية كلية الدعهوة الإسلاهية بالقاهرة}

كع التكوين اللغوي للدعاة وأثره في تجديد الخطاب الديني

r ا جواهر الأدب في أدبيات وإنشاء لغة العرب: السيد أحمد الهاشمي، مكتبة الثقافة الدينية،

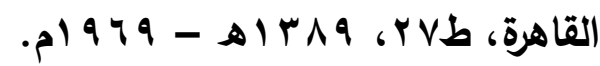

ب ا) حاشية الخضري على شرح ابن عقيل على ألفية ابن مالك، دار الكتب العلمية، بيروت،

$$
\text { . } 1991-81 \leq 19619
$$

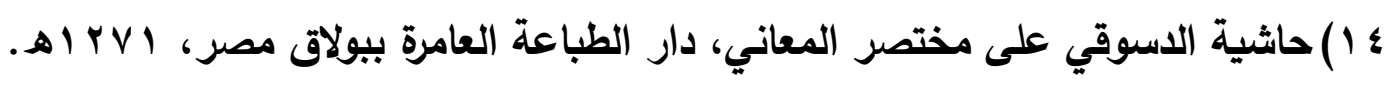
ه 1) حاشية السجاعي على شرح قطر الندى لابن هثام، مطبعة مصطفى البابي الحلبي وأولاده

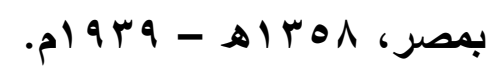

ד 1 ) حاشية العلامة الثيخ حسن العطار على شرح الأزهرية في علم النحو للشيخ خالد الأزهري،

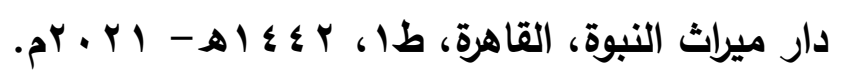

V) الخصائص لابن جني، تحقيق: الأستاذ/ محمد علي النجار، المكتبة العلمية عن طبعة دار

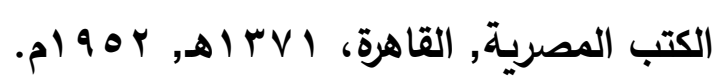

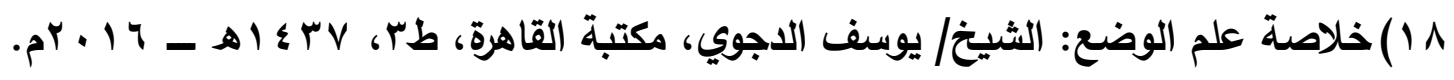
9 1) ديوان حافظ إبراهيم، ضبطه: أحمد أمين، وآخرون، الهيئة المصرية العامة للكتاب، طب،

$$
\text { - }) 9 \wedge \mathrm{V}
$$

• r عروس الأفراح في شرح تلخيص المفتاح: بهاء الاين السبكي، المكتبة العصرية، بيروت،

$$
\text { طا، r }
$$

ا Y) القسطاس في علم العروض: جار الله الزمخثري، تحقيق: د. فخر الدين قباوة، مكتبة

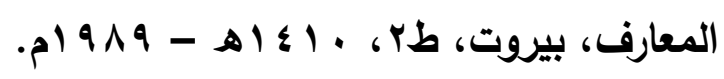

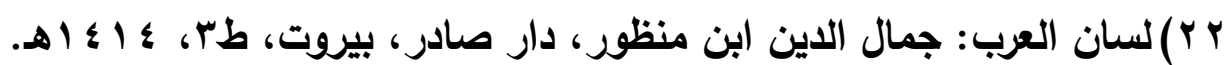

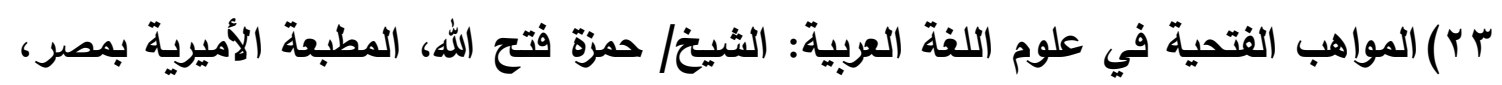

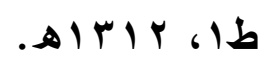

ع Y) الوسيلة الأدبية إلى العلوم العربية: حسين المرصفي، تحقيق: د/ عبد العزيز الاسوقي،

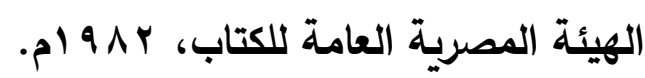

\section{خامسسا: كتب أصول الدين:}

هץ) حاشية الأمير على شرح عبد السلام لجوهرة التوحيد للإمام اللقاني، مكتبة ذخائر الوراقين،

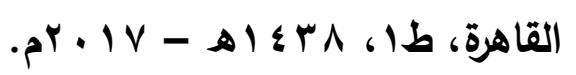

צr) حاشية على الخريدة البهية: سيدي أحمد الصاوي، مطبعة مصطفى البابي الحلبي وأولاده،

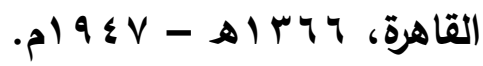




\section{حولية كلية الدعوة الإسلاهية بالقاهرة}

\section{كعبالتكوين اللغوي للدعاة وأثره في تجديد الحطاب الديني}

المواهب اللانية شرح المقدمات السنوسية: أبو إسحاق إبراهيم السرقسطي، مكتبة مصطفى

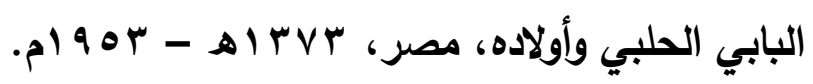

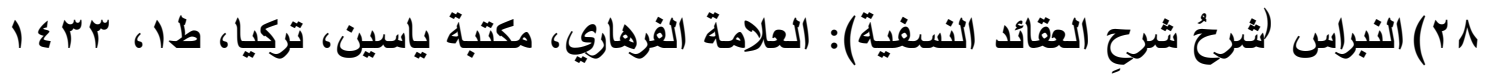

$$
\cdot p_{r} \cdot 1 r-
$$

q Y) النظام الفربد بتحقيق جوهرة التوحيد: محمد محيي الاين عبد الحميد، المكتبة التجارية

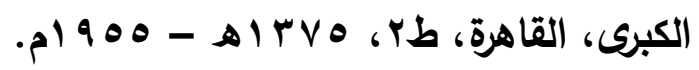

\section{سادساً: كتب أصول الفقهه:}

• ץ) الإبهاج في شرح المنهاج: تقي الدين السبكي، وولده تاج الدين السبكي، تحقيق: د. أحمد جمال الزمزمي، د. نور الاين عبد الجبار، دار البحوث للاراسات الإسلامية، الإمارات العربية

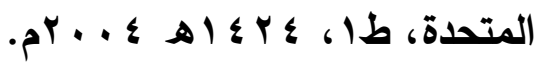

اب) البرهان في أصول الفقه: إمام الحرمين الجويني، تحقيق: صلاح بن محمد بن عوبضة، دار

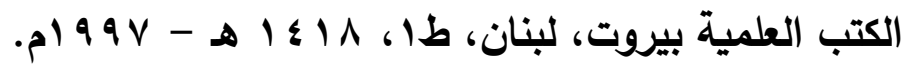

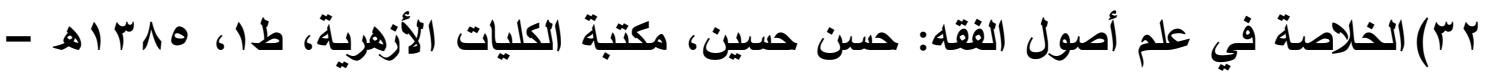

بr) الموافقات في أصول الشربعة: أبو إسحاق الشاطبي، علَّق عليه: محمد عبد الله دراز،

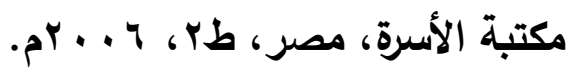

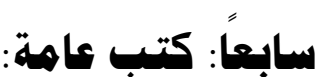

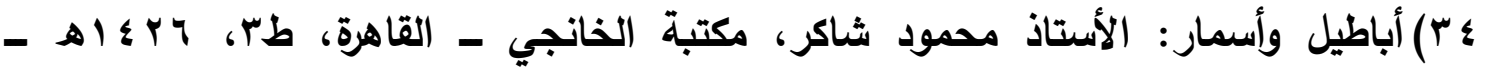

$$
\cdot 0^{r} \cdot 0
$$

ه ץ) أبجد العلوم: صديق بن حسن القنوجي، وزارة الثقافة والإرشاد القومي، دمشق، 9 ام ام. بr) أثر الدرس اللغوي في فهم النص الثرعي: أ.د/ محمد المختار محمد المهدي، حولية كلية

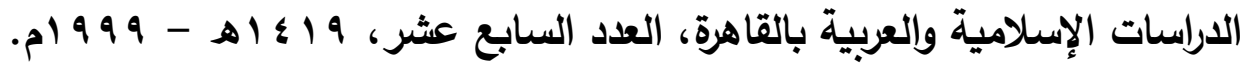
V V إعجاز القرآن: القاضي أبو بكر الباقلاني، مطبعة مصطفى البابي الحلبي وأولاده بمصر،

$$
\text { .p) } 9 \vee \wedge-\operatorname{sirq\Lambda ,~b~}
$$

^ץ) إيضاح المبهم من معاني السلم: العلامة أحمد عبد المنعم الامنهوري، تحقيق: د. مصطفى

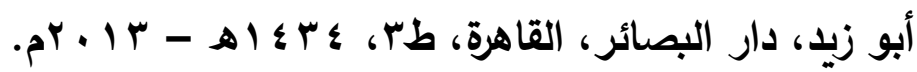
q ب) تاريخ الاعوة إلى العامية وآثارها في مصر : د/ نفوسة زكريا، دار نشر الثقافة بالإسكندرية، 


\section{حولية كلية الدعوة الإسلاهية بالقاهرة}

\section{كئالتكوين اللغوي للدعاة وأثره في تجديد الحطاب الديني}

$$
\text { . ط) }
$$

• ع) تحت راية القرآن: الأستاذ/ مصطفى صادق الرافعي، صحح أصوله تلميذه الأستاذ/ محمد

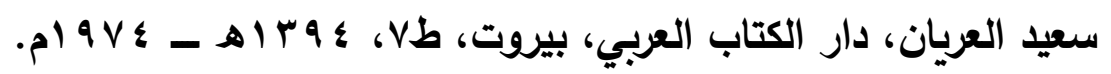
اء) التراث والتجديد مناقثات وردود: الإمام الأكبر/ أحمد الطيب، دار القدس العربي، القاهرة،

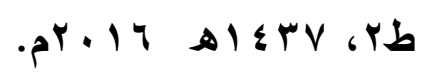
ץء) ترتيب العلوم: محمد بن أبي بكر المرعشي، الثهير بساجقلي زاده، تحقيق: محمد بن

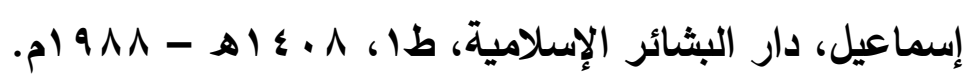
بـ) خلاصة القواعد المنطقية: د/ عبد الغفار عبد الرؤف حسن، تقديم: أ.د/ صابر أحمد طه،

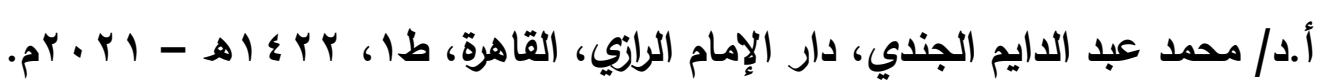
ء \&)دستور العلماء (جامع العلوم في اصطلاحات الفنون): القاضي عبد النبي بن عبد الرسول، عرب عباراته الفارسية: حسن هاني فحص، دار الكتب العلمية - لبنان / بيروت، طاء لهي

$$
\text { .... - D }
$$

ه ؛ دليل معلمة المناهج الأزهرية (قائمة بالكتب المعتمدة في الأزهر الشريف)، تقديم: الإمام

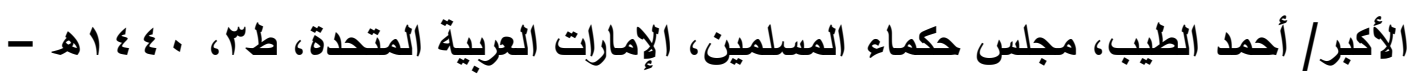

$$
\cdot p^{r} \cdot 19
$$

צ ؛ )رسالة في الطريق إلى ثقافتنا: الأستاذ/ محمود محمد شاكر، مكتبة الخانجي بالقاهرة، طץ،

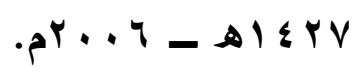

V\& رؤيسة إسلامية في قضايا العصر: أ.د. محمد عبد الفضيل القوصي، هيئة كبار العلماء

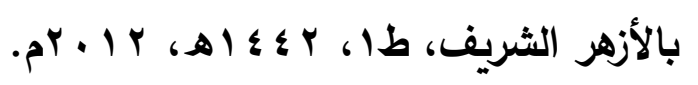

^ء ) على هامش السياسة (بعض مسائلنا القومية): د. حافظ عفيفي باشا، مطبعة دار الكتب

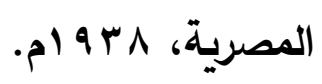

9ء) كثاف اصطلاحات الفنون والعلوم: محمد بن علي ابن القاضي الحنفي التهانوي، تقديم وإثراف ومراجعة: د. رفيق العجم، تحقيق: د. علي دحروج، نقل النص الفارسي إلى العربية: د. عبد الله الخالدي، الترجمة الأجنبية: د. جورج زبناني، مكتبة لبنان ناشرون،

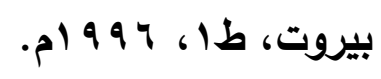

••) كشف الظنون عن أسامي الكتب والفنون: حاجي خليفة مصطفى بن عبد الله، المشهور

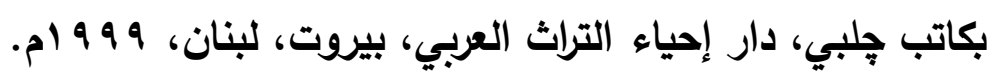

اه) اللؤلؤ المنظوم في مبادئ العلوم: محمد أبي عليان الثافعي، المطبعة الحسينية بمصر، 


\section{حولية كلية الدعوة الإسلاهية بالقاهرة}

كئالتكوين اللغوي للدعاة وأثره في تجديد الحطاب الديني

. ATYO

Yo) المختار: عبد العزيز البشري، مطبعة لجنة التأليف والترجمة والنشر، مصر، ؛ه آهـ - 19 ro

به) المساجلات الفكرية بين الأستاذ محمود شاكر ومعاصريـه: د. عبد الغفار عبد الرؤف حسن،

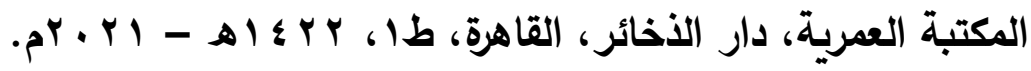

؛ه) مشكلة اللغة العربية، لماذا أخفقنا في تعليمها، وكيف نعلمها: الثيخ/ محمد عرفة، تقديم: أ.د// حسن الثافعي، أ.د/ نظير محمد عياد، هدية مجلة الأزهر، جمادى الأولى سنة

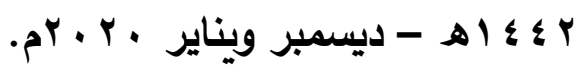

هـ)مفتاح السعادة ومصباح السيادة في موضوعات العلم: أحمد بن مصطفى، الثهير بطاش

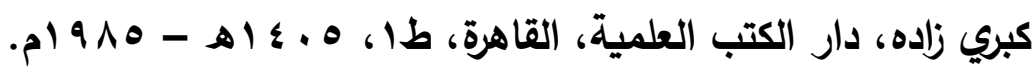
\ه)مقالات العلامة الاكتور محمود محمد الطناحي، دار البشائر الإسلامية ـ بيروت، طا،

$$
\cdot P r \cdot r-\Delta \leqslant r
$$

Vه)مقدمة ابن خلدون: عبد الرحمن بن محمد بن خلدون، تحقيق: د. علي عبد الواحد وافي،

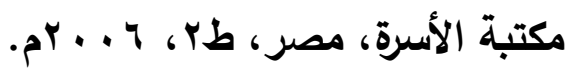

^ه) من جهود الأزهر في التجديد: تقديم: أ.د/ عباس شومان، هدية مجلة الأزهر، عدد: رجب

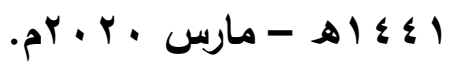

9ه) منهجية التفكير العلمي في ضوء القواعد الأصولية: أ.د. محمود عبد الرحمن عبد المنعم،

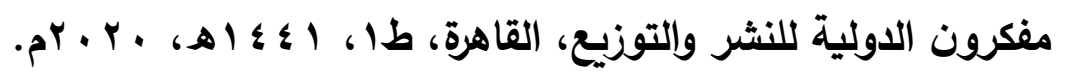

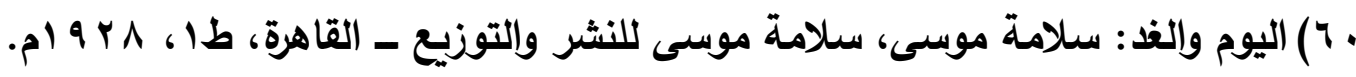

\section{ثاهنًا: المبلات والدوريات:}

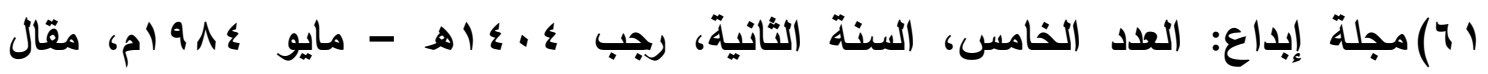

$$
\text { للاكتور/ محمود الربيعي، بعنوان: من مشكلات الحداثة. }
$$

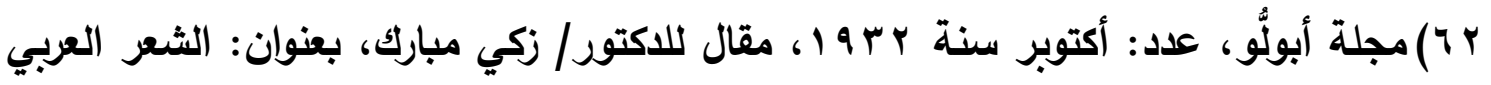
بين اليقظة والجمود.

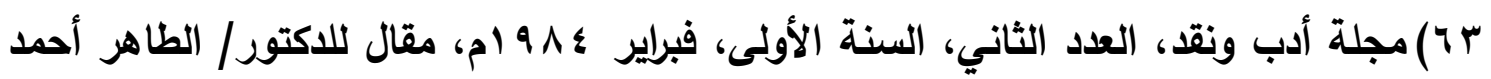
مكي، بعنوان: مقالات الاستعمار والتخريب الثقافي. צ 7)مجلة الأديب، السنة اب، الجزء الرابع، أبريل سنة وVY ام، مقال للأستاذ/ عيسى الناعوري، بعنوان: لماذا نحن شعب لا يقرأ؟. 


\section{حولية كلية الدعهوة الإسلاهية بالقاهرة}

كع النكوين اللغوي للدعاة وأثره في تجديد الخطاب الديني

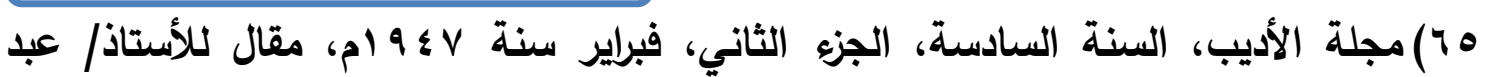

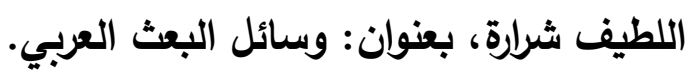

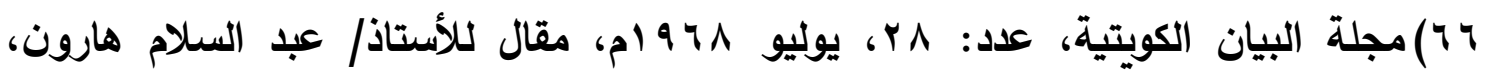
بعنوان: علاقة الإسلام باللغة العربية.

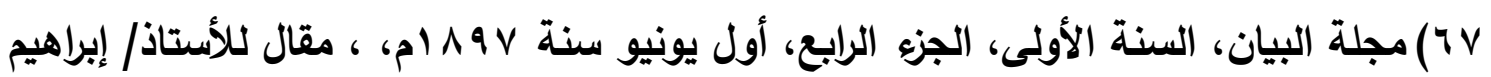
اليازجي، بعنوان: اللغة والعصر .

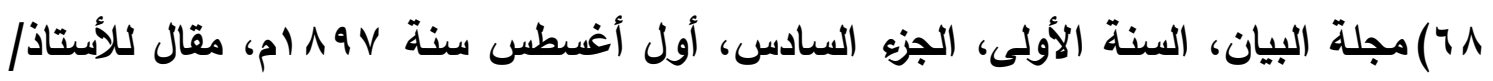
إبراهيم اليازجي، بعنوان: اللغة وإلعصر (تابع).

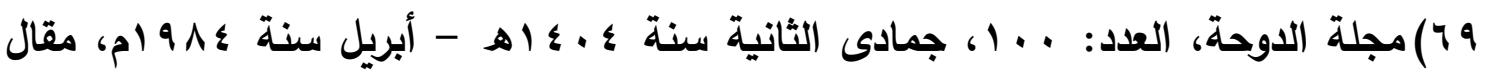

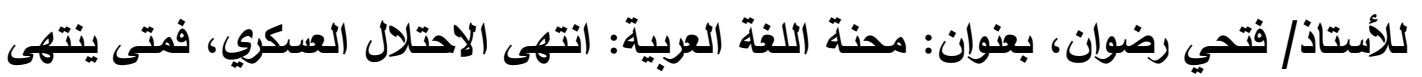
الاحتلال اللغوي ؟!.

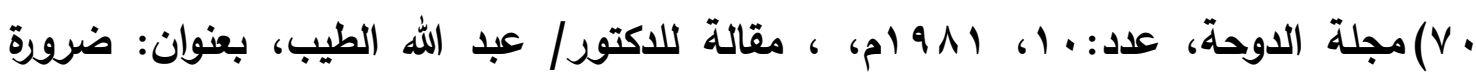
الرجوع إلى القرآن الكريم في التعليم.

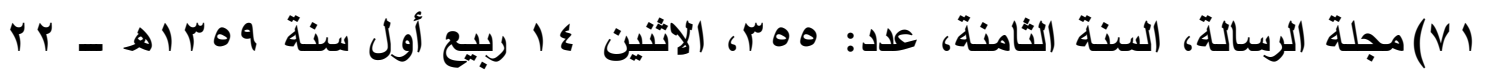

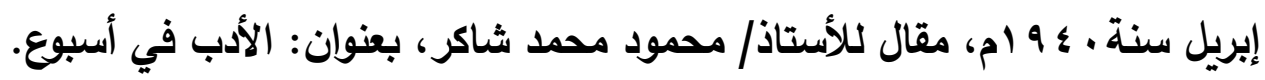

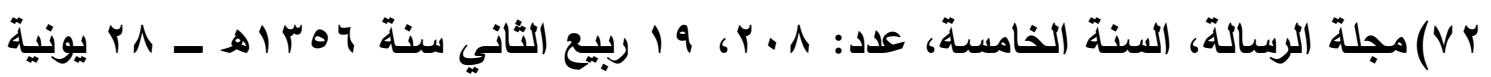

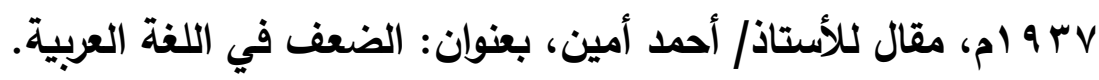

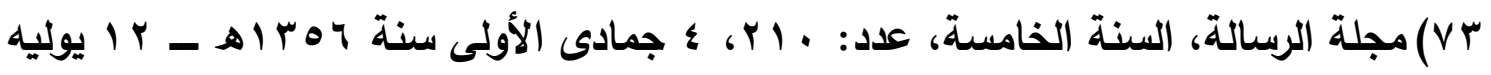
PrV

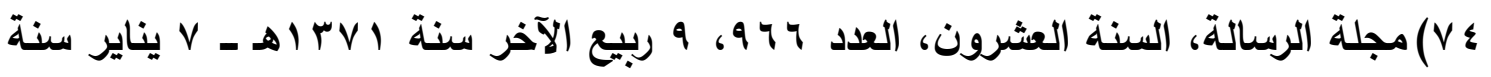

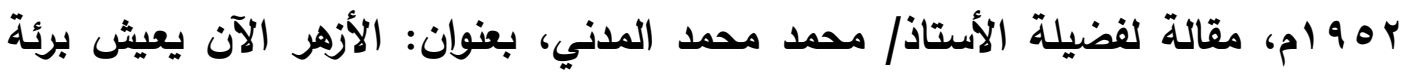
واحدة.

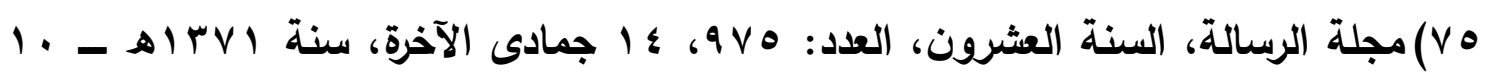

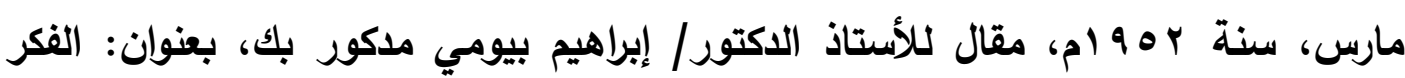
واللغة.

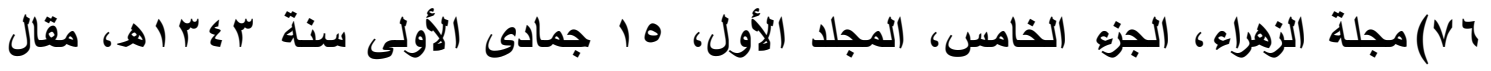

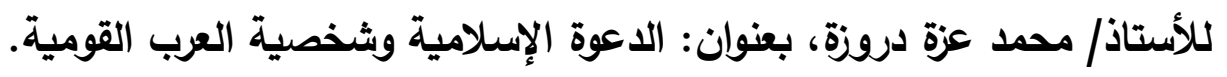

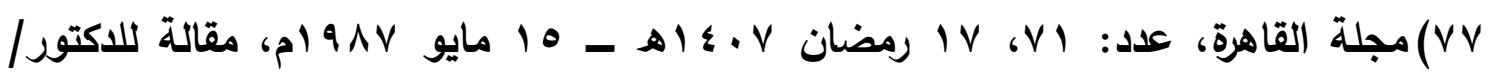




\section{حولية كلية الدعهوة الإسلاهية بالقاهرة}

كع التكوين اللغوي للدعاة وأثره في تجديد الخطاب الديني

إبراهيم مدكور، بعنوان: توصيات مؤتمر مجمع اللغة العربية بالقاهرة في الدورة الثالثة

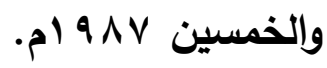

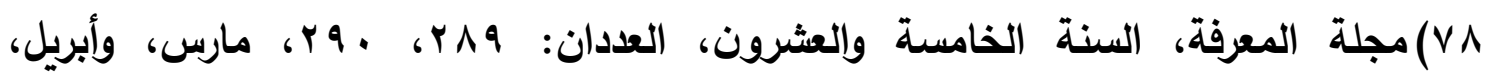
\ 9 ام، مقالة للاكتور/ مازن المبارك، بعنوان: آفاق المعرفة- نحو منهج تكاملي لعلوم

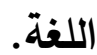

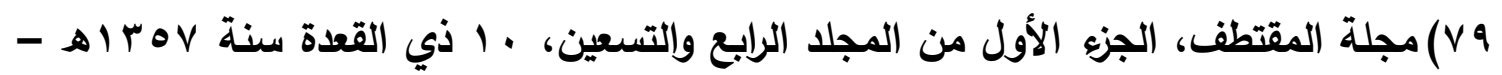
ا يناير سنة و q ام، مقال للأستاذ/ علي حافظ، بعنوان: الطبيعة الميتافيزيقية والعلوم التجربية.

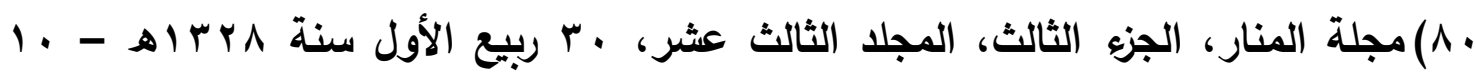
أبريل سنة . 91 ام، مقال للإمام الأكبر/ محمد الخضر حسين، بعنوان: أطوار اللغة العربية.

1^)مجلة مجمع اللغة العربية الملكي، الجزء الأول، رجب سنة بهابه ـ ـ أكتوبر سنة

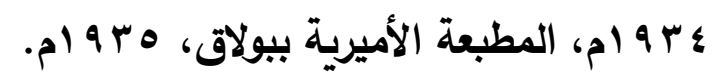

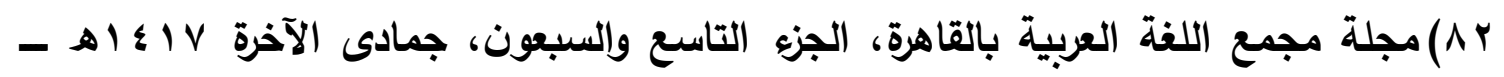
نوفمبر 99 ام، تعريب التعليم الجامعي، أ.د/ عبد الحافظ حلمي محمد.

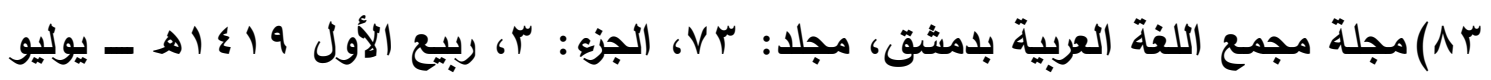
^9 9 ام، مقال للاكتور: عبد الله الطيب، بعنوان: مشكلة الأداء في اللغة العربية.

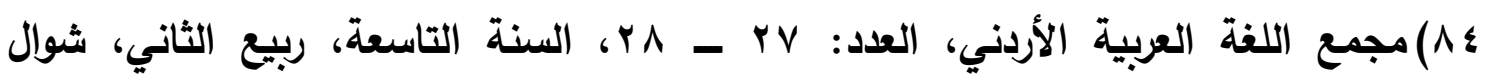

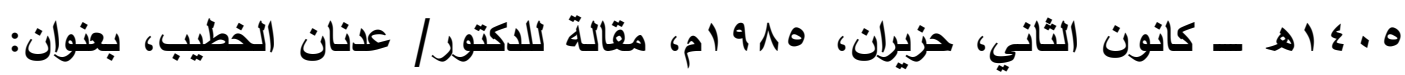
وقائع مؤتمر مجمع اللغة العربية بالقاهرة في دورته الخمسين \& ؟ 9 ام.

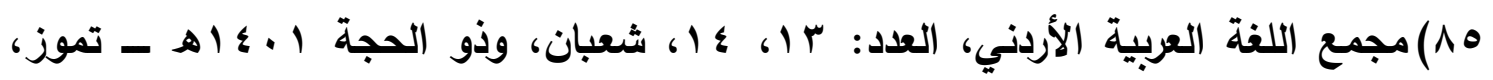
وكانون الأول اه^وام، السنة الرابعة، مقالة للدكتور/ عدنان الخطيب، بعنوان: وقائع

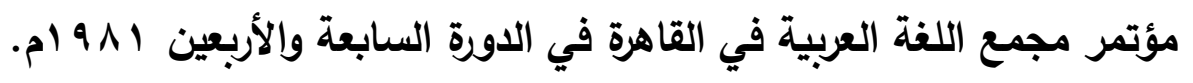


كعالتكوين اللغوي للدعاة وأثره في تجديد الخطاب الديني

\section{فهرس}

\section{المحتويات}

91

ملخص البحث: .

$1,$. مقدمة .

1.1

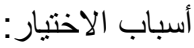

$1 \cdot 1$

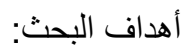

$1 \cdot 1$

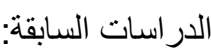

$1 \cdot 1$ منهج البحث:

$1 \cdot r$

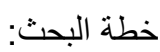

$1 \cdot r$ تمريد .

$1 \cdot r$. تحرير مدلول بعض مصطلحات عنوان البحث.

$1 \cdot v_{\text {. }}$

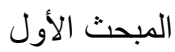

$1 \cdot v$ العلوم العربية وعلاقتها بالهوية الإسلامية

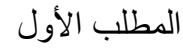

$1 \cdot v$.

110

110 أنو اع المعارف في المنظومة المعرفية الأزهرية ...

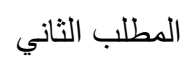
الارتباط بين اللغة العربية و الهؤية الإسلامية

119

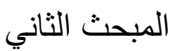

119 الو اقع اللغوي للاعاة

ir.

IrT

IrT

IrT

ITr

ir人

IrA

iro

1 ro

itro

149

147

ITV
المظاهر العامة للضعف اللغوي: المبحث الثالث مقوضات الازدهار اللغوي للاعاة.

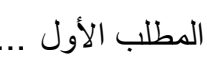

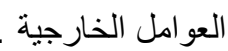

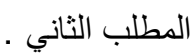

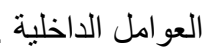

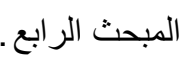
عوامل تنمية الملكة اللغوية للاعاة . أولًا: علم النحو: .... ثنانيًا: علم الصرف:

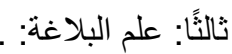
رابعًا: علم منن اللغة: المبحث الخامس.

$1 \leq 0$ آثار التمكُن من العربية في تجديد الخطاب الديني . 
حولية كلية الدعهوة الإسلاهية بالقاهرة

كع التكوين اللغوي للدعاة وأثره في تجديد الحطاب الديني

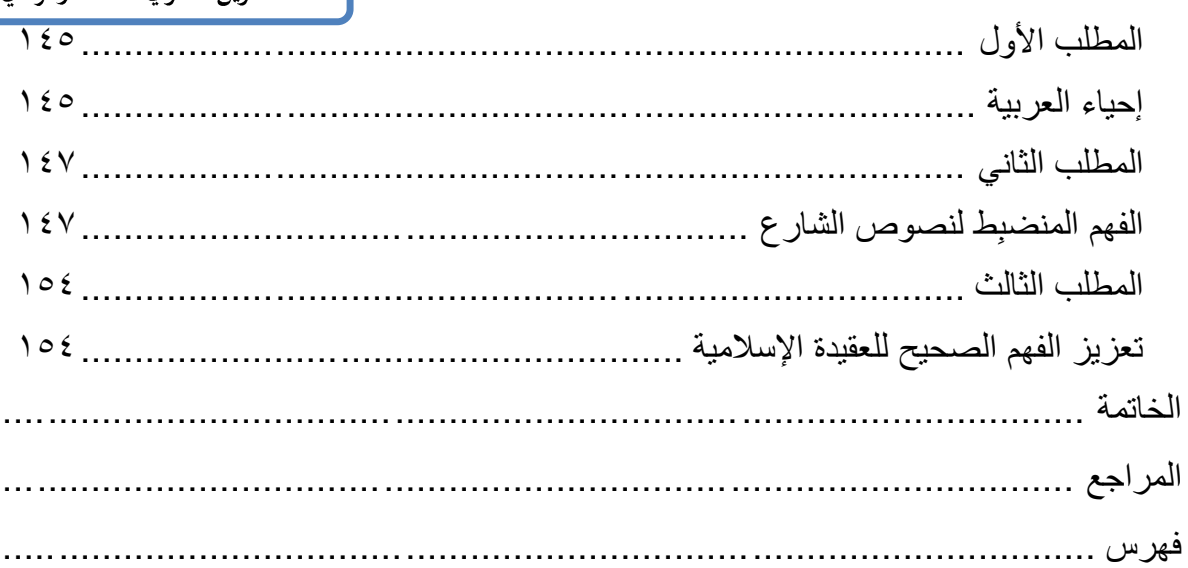

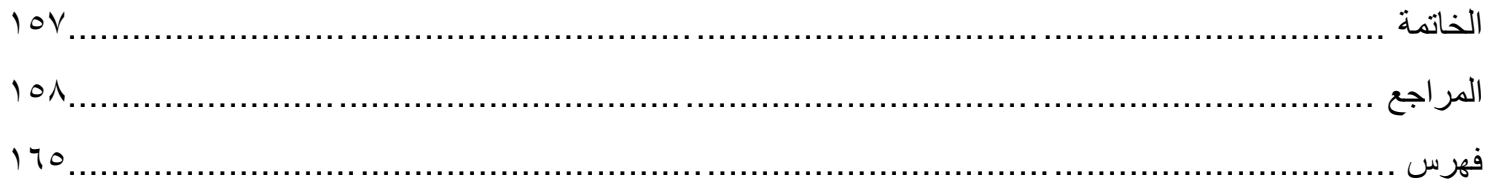

